\title{
Thermochemical and Catalytic Conversion Technologies for the Development of Brazilian Biomass Utilization
}

\author{
Caroline Carriel Schmitt ${ }^{1, *}$, Frederico Gomes Fonseca ${ }^{1}$, Mariana M. Campos Fraga ${ }^{1}$, Alberto Wisniewski, Jr. ${ }^{2}{ }^{10}$, \\ Susan Karp ${ }^{3}$, Álvaro Henrique Mello José ${ }^{4}$, Rita C. L. B. Rodrigues ${ }^{4}$, Renata Moreira ${ }^{5}$, Danilo Eiji Hirayama ${ }^{5}$, \\ Klaus Raffelt ${ }^{1}$ and Nicolaus Dahmen ${ }^{1}$
}

Citation: Schmitt, C.C.; Fonseca, F.G. Fraga, M.M.C.; Wisniewski, A., Jr.; Karp, S.; Mello José, Á.H.; Rodrigues, R.C.L.B.; Moreira, R.; Hirayama, D.E.; Raffelt, K.; et al. Thermochemical and Catalytic Conversion Technologies for the Development of Brazilian Biomass Utilization. Catalysts 2021, 11, 1549. https://doi.org/10.3390/ catal11121549

Academic Editors: Alessandra Palella and Lorenzo Spadaro

Received: 19 November 2021 Accepted: 7 December 2021

Published: 19 December 2021

Publisher's Note: MDPI stays neutra with regard to jurisdictional claims in published maps and institutional affiliations.

Copyright: (c) 2021 by the authors. Licensee MDPI, Basel, Switzerland. This article is an open access article distributed under the terms and conditions of the Creative Commons Attribution (CC BY) license (https:/ / creativecommons.org/licenses/by/ $4.0 /)$.
1 Institute of Catalysis Research and Technology, Karlsruhe Institute of Technology, 76344 Karlsruhe, Germany; frederico.fonseca@kit.edu (F.G.F.); mariana.fraga@partner.kit.edu (M.M.C.F.); klaus.raffelt@kit.edu (K.R.); nicolaus.dahmen@kit.edu (N.D.)

2 Department of Chemistry, Universidade Federal de Sergipe, Saint Cristopher 49100-000, Brazil; albertowj@ufs.br

3 Bioprocess and Biotechnology Engineering, Universidade Federal do Paraná, Curitiba 81530-000, Brazil; susan.karp@ufpr.br

4 Department of Biotecnology, Escola de Engenharia de Lorena, Universidade de São Paulo, Lorraine 12602-810, Brazil; alvaro_he@usp.br (Á.H.M.J.); rita@debiq.eel.usp.br (R.C.L.B.R.)

5 Institute for Technological Research, IPT, Sao Paulo 05508-901, Brazil; renatam@ipt.br (R.M.); eijidan@ipt.br (D.E.H.)

* Correspondence: caroline.schmitt@partner.kit.edu

Abstract: The social, economic, and environmental impacts of climate change have been shown to affect poorer populations throughout the world disproportionally, and the COVID-19 pandemic of 2020-2021 has only exacerbated the use of less sustainable energy, fuel, and chemical sources. The period of economic and social recovery following the pandemic presents an unprecedented opportunity to invest in biorefineries based on the pyrolysis of agricultural residues. These produce a plethora of sustainable resources while also contributing to the economic valorization of first-sector local economies. However, biomass-derived pyrolysis liquid is highly oxygenated, which hinders its long-term stability and usability. Catalytic hydrogenation is a proposed upgrading method to reduce this hindrance, while recent studies on the use of nickel and niobium as low-cost catalysts, both abundant in Brazil, reinforce the potential synergy between different economic sectors within the country. This review gathers state-of-the-art applications of these technologies with the intent to guide the scientific community and lawmakers alike on yet another alternative for energy and commodities production within an environmentally sustainable paradigm.

Keywords: biomass; fast pyrolysis; catalytic conversion; hydrodeoxygenation; catalysts; catalytic pyrolysis; agriculture residues; biorefineries; bioeconomy

\section{Introduction}

The year 2021 is a landmark in human history. The COVID-19 pandemic claimed, to date, more than 5 million lives throughout the globe [1] and led governments, institutions, and individuals to adopt safety measures that promoted drastic changes in social behavior, habits, and consumption patterns. Many countries and municipalities adopted social isolation as an intent to avoid viral dissemination rates that could collapse their health systems. Meanwhile, the suspension of many economic activities led to an inevitable economic crisis. Unemployment and loss of purchasing power are some of its facets and affected, largely, the most vulnerable classes of society. According to the International Monetary Fund, the worldwide unemployment rate increased from $6.9 \%$ in 2019 to $9.5 \%$ in 2020 [2]. The situation in Brazil, which is currently unfavorable, with an unemployment rate of $11.9 \%$, is expected to soar to $14.7 \%$ (according to data from the International Monetary Fund). 
This unprecedented situation draws attention to the vulnerability of our human systems to a biological agent. Not only this disease, but also many others that (even being treatable) kill millions of people annually, and could be prevented by the provision of basic sanitation conditions, or controlled by assertive diagnosis and treatment, open our eyes to the weaknesses of the structures that compose our relationship with our habitat and community. These weaknesses can be related to environmental, social, and economic aspects that are all objects of intervention in the context of the bioeconomy.

The relation between climate change and the pandemic was addressed by Pinner, Rogers, and Samandari [3], who highlighted similarities and differences between the two phenomena and demonstrated how these two threats could be combated together. Regarding the similarities, both represent physical shocks that will cause socioeconomic impacts and could only be solved by acting against the physical causes. The main differences, on the other side, are represented by the timeframe to observe the effects (which is much shorter in the case of pandemics) and the nature of their progression. While the effects of a public health crisis are imminent and directly noticeable, the consequences of climate change are cumulative and gradual and will be observable in years, decades, or centuries.

Recently, climate change was associated with the spread of infectious diseases. The urbanization of forest areas or their conversion to croplands is one of the risk factors for the spread of zoonotic infectious diseases, either by inducing animal species to migrate or by keeping humans, animal reservoirs, and vectors in close contact. In this sense, the same factors that reduce environmental impacts (conservation, optimization of land use, reduction of animal protein consumption, mitigation of pollution) are likely to avoid the dissemination of infectious diseases [3].

Concerning economy and socio-economic development, as pointed out by Chiaramonti and Maniatis [4], one big lesson to be learned in the post-COVID scenario is the importance of the security of supply and storage. This became evident, along the first months of 2020, for health and protective material. However, controlling strategic supply chains through domestic channels and developing strategic storage is an important action to be adopted in other spheres, such as food and energy security. According to the authors, domestic sources, such as renewable and recycled carbon fuels, are an alternative to be pursued to ensure a secure energy supply in the European Union.

In this sense, each country should focus on the conversion of domestic resources to generate energy and other goods and services. This is especially valid for those countries that generate expressive amounts of biomass (either as dedicated crops or as industrial coproducts) that are, to a great extent, subtilized. Examples include South American countries that, according to Magalhães et al. [5], will generate about 900 million tons of lignocellulosic biomass (sugarcane bagasse, cereal straws, bananas, and oil-palm biomass) by 2025, which could potentially generate, annually, more than 550 million tons of fermentable sugars, 670 million tons of bio-oil, or 4000 TWh of thermal energy.

Bioproducts and energy should be obtained from domestic renewable resources not only for supply security reasons but also to promote the creation of jobs, stimulate innovation, and sustainably boost the economy. Minimizing long-distance transportation, particularly of materials of low density, promotes the utilization of the local availability of biomass resources to be valorized in customized biorefineries co-producing food, feed, materials, and/or energy by full utilization of the used biomass in cascaded process chains. As stated by the International Labour Organization, a greener economy could result in the loss of around 6 million jobs worldwide, as 24 million new positions would be created by 2030. Considering that an estimated 1.2 billion jobs positions depend on good environmental conditions, like in agriculture, forestry, and even tourism, this is an advantageous change of the paradigm [6]. So, local partnerships and international cooperation should be pursued to synergistically unite competencies and common goals, aiming at the accelerated transition to a bio-based economy.

Therefore, based on the requirement for renewable and sustainable sources of energy for a post-COVID economic recovery, this manuscript presents a review of the current 
Brazilian energy production and biomass availability in the country. After introducing lignocellulosic biomass as a feedstock, a review of biomass available in Brazil, as well as the state-of-the-art of thermochemical conversion methods with potential for biofuels production, is provided, mainly focused on sugarcane-based materials. Thermochemical processes, specifically related to fast pyrolysis are introduced for the production of biooils followed by catalytic hydrotreatment. Based on this, a pyrolysis-centered sugar cane biorefinery is suggested as well as alternative bio-based process chains.

\section{Biomass and Lignocellulosic Biomass}

Biomass is a renewable resource considered abundant, and manageable worldwide, which can be transformed into valuable commodities using different processes, being mechanical (e.g., pelletizing), biochemical (e.g., fermentation), or thermochemical (e.g., pyrolysis). The use of biomass or its derived commodities for the production of energy can minimize the reliance on petroleum-based fuels and greenhouse gas (GHG) emissions while promoting energy access and economic independence for communities and countries [7]. In terms of energy production, biomass is often considered the amount of organic matter that can be converted into fuel or heat.

Often, one can categorize biomass into four categories: woody, herbaceous, algal, and waste-based. Woody biomass comprises wood itself, and residues derived from trees and shrubs, as well as forestry industries (including branches, leaves, bark, sawdust). Herbaceous biomass comes from crops and plant species, such as wheat, barley, corn, maize, switchgrass, sugarcane, and many others.

Lignocellulosic biomass is essentially a combination of natural polymers arranged in matrix building blocks, being hemicellulose, lignin, and cellulose. Different types of biomass, such as grasses, softwood, and hardwood, have different concentrations of these units.

In general, lignin corresponds to approximately 10 to $25 \mathrm{wt} . \%$ of the biomass, hemicellulose corresponds to around 20 to $30 \mathrm{wt} . \%$, while cellulose corresponds to 40 to $50 \mathrm{wt} . \%$ [8]. Other substances, such as inorganics and extractives, might also be part of the biomass composition [9] (Figure 1).

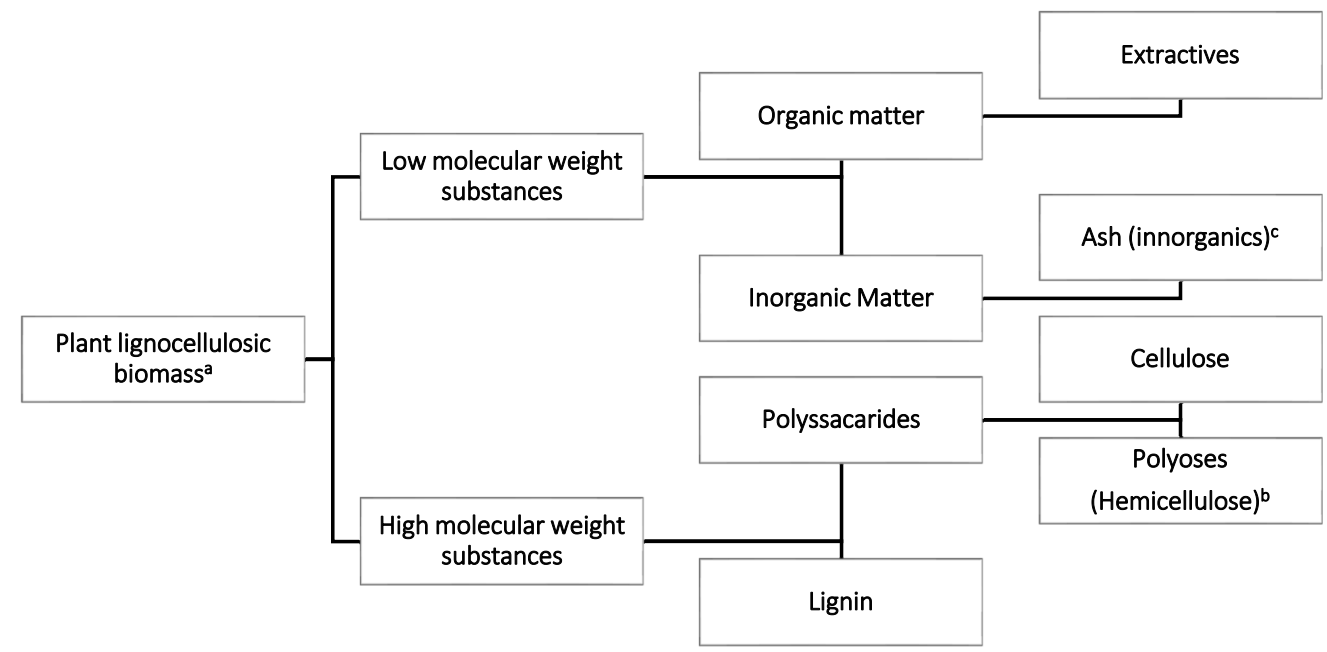

Figure 1. Overview of the lignocellulosic biomass components. Adapted with permission from Mohan, D. et al. [9] (2006). Copyright 2006 Copyright ACS Publications.

Every building block has a particular function in the lignocellulosic biomass. Cellulose, which is mainly composed of cellobiose units (a disaccharide of $\beta$-glucose units), gives strength to the plant. At the same time, hemicellulose shows a heteropolysaccharide structure composed of a variety of carbohydrates including but not limited to glucose, mannose, xylose, and galactose [9,10]. Lignin, which is composed of sinapyl, p-coumaryl, 
and coniferyl alcohol units, is responsible for the microbial and fungal resistance of the plant and also and gives stability to the cell walls [8-10].

Extractives are associated with plant defense mechanisms and include components such as essential oils, pectins, terpenes, waxes, and mucilages $[9,11]$. Some lignocellulosic biomasses, such as corn stover, wheat straw, and switchgrass, do not contain extractives while forest residues, pine needles, and eucalyptus might have a high concentration of extractives, from 5 to approximately $12.6 \mathrm{wt} . \%$ [11]. The ash is composed of inorganic substances, such as $\mathrm{Mg}, \mathrm{K}, \mathrm{Na}, \mathrm{P}, \mathrm{Si}$, and $\mathrm{P}[9,11,12]$. The concentration and composition of this ash depend on the lignocellulosic biomass and the cultivation conditions and may affect the valorization pathway chosen. The ash concentration is usually higher in fastgrowing lignocellulosic biomasses, like miscanthus (12.9 wt.\%), while in wood, i.e., pine (1.2 wt.\%), the concentration of ash is usually lower [13,14].

The carbon concentration in the lignocellulosic biomass remains in the range of 42.8 to $49.6 \mathrm{wt} . \%$, hydrogen around 5 to $6 \mathrm{wt} . \%$, while oxygen remains in the range of $39 \mathrm{up}$ to approximately $43.2 \mathrm{wt} . \% \mathrm{db}$. [13]. The higher heating is usually in the range of 16.6 to $18.7 \mathrm{MJ} / \mathrm{kg}[13]$.

\subsection{Renewable Energy and Biomass Availability in Brazil}

First-generation biofuels concern the use of energy crops (soy, Jatropha, among others) for the production of biofuels. However, there is concern about the use of arable land for fuel production instead of food/feed production, and other limitations [15,16]. The processing of these herbaceous crops produces a high amount of wastes, and biofuels produced from these wastes are part of the second generation of biofuels [15]. Algal biomass produces the so-called third-generation biofuels with higher energy outputs [17]. Biological wastes, such as farming residues, paper industry residues, food production waste, and water treatment sludge, are also considered a form of biomass [18].

Yet, the application of biomass as a carbon/energy source is not without controversy. Many problems associated with agricultural practices and expansions are already a factor of concern, such as deforestation, soil and water contamination, biodiversity reduction, and GHG emissions. The conversion of so-called energy crops into first-generation biofuels would increase the extent of these problems, as their market value can sway many landowners to stop producing food and feed products, increasing their price, and limiting availability. In this sense, the use of biomass residues can provide landowners with additional sources of revenue from a low-value by-product, while not competing with the production of food/feed [7].

Brazil is one of the leading world biomass producers due to its large crop production; however, the country presents an estimated recovery rate for agricultural residue up to $10 \%$, considered negligible. Although by 2050 , it is forecast that up to $40 \%$ of forestry and agricultural residues may be harvestable through technological advances for bioenergy purposes [19] and being economically attractive in the country. Among the main crops grown in Brazil, the following stand out: rice, beans, soybeans, corn, wheat, and sugar cane (Table 1). Hence, estimated amounts of waste generated in 2012 reached 298 MTon for the sum of the main crops. Brazilian forests of pine and eucalyptus, estimated in 2012, produced waste up to $6,020,470 \mathrm{~m}^{3}$ [20].

Table 1. Main agriculture crops produced in Brazil. Characterization of residual biomass.

\begin{tabular}{|c|c|c|c|c|c|c|c|c|c|c|}
\hline & Residue & $\begin{array}{c}\text { Annual } \\
\text { Production } \\
2019 \text { Brazil } \\
\left(\times 10^{6} \mathrm{~kg}\right) \\
{[21,22]}\end{array}$ & $\begin{array}{c}\text { Cellulose } \\
\text { (wt.\%) }\end{array}$ & $\begin{array}{l}\text { Hemicellulose } \\
\text { (wt.\%) }\end{array}$ & $\underset{\text { (wt.\%) }}{\text { Lignin }}$ & $\begin{array}{c}\text { Extractives } \\
\text { (EtOH) } \\
\text { (wt.\%) }\end{array}$ & $\begin{array}{l}\text { Others } \\
\text { (wt. \%) }\end{array}$ & $\begin{array}{c}\text { Ash } \\
\text { (wt. \%) }\end{array}$ & $\begin{array}{l}\text { Pectin } \\
\text { (wt. \%) }\end{array}$ & References \\
\hline Sugarcane & $\begin{array}{l}\text { Sugarcane } \\
\text { bagasse }\end{array}$ & 657,532 & $36.9-42.8$ & $21.0-27.2$ & $17.4-33.71$ & $2.78-12.7$ & $\mathrm{n} / \mathrm{a}$ & $0.68-6.71$ & $\mathrm{n} / \mathrm{a}$ & {$[23,24]$} \\
\hline Corn & Corncob & 100,566 & $28.0-44.1$ & $26.8-44.4$ & $11.9-23.9$ & $5.8-10.5$ & $\mathrm{n} / \mathrm{a}$ & $1.1-2.1$ & $\mathrm{n} / \mathrm{a}$ & [25-30] \\
\hline Piassava & $\begin{array}{l}\text { Piassava } \\
\text { fibers }\end{array}$ & $8.5(2018)$ & $29.6-31.6$ & 0-11.0 & $45.0-48.4$ & $\mathrm{n} / \mathrm{a}$ & $\mathrm{n} / \mathrm{a}$ & $\mathrm{n} / \mathrm{a}$ & $\mathrm{n} / \mathrm{a}$ & {$[31,32]$} \\
\hline Cassava & $\begin{array}{l}\text { Cassava } \\
\text { peel }\end{array}$ & 18,990 & $7-37.9$ & $4.9-37$ & $7.6-65.0$ & $\mathrm{n} / \mathrm{a}$ & $7.6-20.11$ & $4.5-8.33$ & $\mathrm{n} / \mathrm{a}$ & {$[28,33-36]$} \\
\hline
\end{tabular}


Table 1. Cont.

\begin{tabular}{|c|c|c|c|c|c|c|c|c|c|c|}
\hline & Residue & $\begin{array}{c}\text { Annual } \\
\text { Production } \\
2019 \text { Brazil } \\
\left(\times 10^{6} \mathrm{~kg}\right) \\
{[21,22]}\end{array}$ & $\begin{array}{l}\text { Cellulose } \\
\text { (wt.\%) }\end{array}$ & $\underset{(w t . \%)}{\text { Hemicellulose }}$ & $\underset{\text { (wt.\%) }}{\text { Lignin }}$ & $\begin{array}{c}\text { Extractives } \\
\text { (EtOH) } \\
\text { (wt.\%) }\end{array}$ & $\begin{array}{l}\text { Others } \\
\text { (wt.\%) }\end{array}$ & $\begin{array}{c}\text { Ash } \\
\text { (wt.\%) }\end{array}$ & $\begin{array}{l}\text { Pectin } \\
\text { (wt.\%) }\end{array}$ & References \\
\hline Wheat & $\begin{array}{l}\text { Wheat } \\
\text { straw }\end{array}$ & 5231 & $31-40.4$ & $15.5-30.6$ & $17.7-21.5$ & $4.6-6.5$ & - & $7.6-7.7$ & $\mathrm{n} / \mathrm{a}$ & [37-40] \\
\hline $\begin{array}{l}\text { Rice } \\
\text { Soy }\end{array}$ & $\begin{array}{l}\text { Rice peel } \\
\text { Soy peel }\end{array}$ & $\begin{array}{r}10,260 \\
113,448\end{array}$ & $\begin{array}{c}30.6-52 \\
22.4-35.8\end{array}$ & $\begin{array}{l}12-21.0 \\
13-23.1\end{array}$ & $\begin{array}{l}23.9-21 \\
7.6-17.5\end{array}$ & $\begin{array}{l}2.3-2.6 \\
\quad 6.8\end{array}$ & $\begin{array}{l}- \\
-\end{array}$ & $\begin{array}{l}10-15.9 \\
1.1-6.7\end{array}$ & $\begin{array}{l}\mathrm{n} / \mathrm{a} \\
\mathrm{n} / \mathrm{a}\end{array}$ & $\begin{array}{c}{[28,29,41-43]} \\
{[28,43,44]}\end{array}$ \\
\hline $\begin{array}{l}\text { Citrus } \\
\text { (orange) }\end{array}$ & $\begin{array}{l}\text { Orange } \\
\text { peel }\end{array}$ & 17,614 & $11.9-26.1$ & $11.9-14.4$ & $0.2-4.8$ & $\mathrm{n} / \mathrm{a}$ & - & $\mathrm{n} / \mathrm{a}$ & $17-21.3$ & {$[30,44,45]$} \\
\hline Coconut & $\begin{array}{l}\text { Coconut } \\
\text { hull }\end{array}$ & 2340 (2017) & $29.2-32.4$ & $10.3-17.6$ & $36-49.1$ & $1.4-14.1$ & - & $2.96-8.39$ & $\mathrm{n} / \mathrm{a}$ & {$[43,46,47]$} \\
\hline $\begin{array}{l}\text { Gramineous } \\
\text { Crops }\end{array}$ & $\begin{array}{l}\text { Elephant } \\
\text { grass }\end{array}$ & $\mathrm{n} / \mathrm{a}$ & $27.5-40.3$ & $9.19-28.13$ & $15.6-21.7$ & $11.5-14.4$ & - & $7.3-13$ & $\mathrm{n} / \mathrm{a}$ & {$[39,43,48,49]$} \\
\hline Coffee & $\begin{array}{l}\text { Coffee } \\
\text { husk }\end{array}$ & 2995 & $35.3-36.0$ & $29.4-30.2$ & $24.5-31.1$ & $4.2-16$ & - & 2 & $\mathrm{n} / \mathrm{a}$ & {$[29,43]$} \\
\hline Sorghum & $\begin{array}{c}\text { Sorghum } \\
\text { bagasse }\end{array}$ & 2596 & $30-38.0$ & $17.3-22.2$ & $17.4-21.4$ & 7.7 & - & $1.7-9.0$ & $\mathrm{n} / \mathrm{a}$ & [50-52] \\
\hline Barley & $\begin{array}{l}\text { Barley } \\
\text { straw }\end{array}$ & 400 & $30.6-43$ & $24-46.8$ & $6.3-16.3$ & $8.1-8.9$ & - & $3.5-9.5$ & $\mathrm{n} / \mathrm{a}$ & {$[40,53,54]$} \\
\hline Açai & $\begin{array}{l}\text { Açai } \\
\text { seed }\end{array}$ & $\mathrm{n} / \mathrm{a}$ & 8.66 & 59.05 & 17.3 & 9.5 & - & 0.69 & $\mathrm{n} / \mathrm{a}$ & [43] \\
\hline
\end{tabular}

n/a: Not available.

\subsection{Sugarcane}

The Brazilian sugar and alcohol industries operate in a sustainable environment when compared with other countries. The recent market fluctuations and the consequences related to the coronavirus pandemic resulted in an estimated production of 631 million metric tons of sugar harvested for the $2020 / 21$ season, which means a $1.9 \%$ reduction compared to the volume produced in 2019/20, reducing the perspective of production in the harvest. Even so, Brazil leads the world ranking as the largest producer of sugarcane, having great importance for Brazilian agribusiness [55], and an example of a potential raw material to be adapted to the concept of a biorefinery [56].

Sugarcane (Saccharum spp.) is classified as a perennial grass with a height of 2-5 m height. This plant employs has a $\mathrm{C}_{4}$ carbon dioxide fixation process during photosynthesis, guaranteeing a high efficiency to convert radiant into chemical energy [57]. The composition of the useful part of the so-called aerial plant consists of stalks made up of fibers (cellulose, lignin, cellulose, and hemicellulose) and sugars (lactose, sucrose, and fructose) and the tips and leaves, constituting the cane straw. Bagasse, straw, and sugar have nearly the same proportions, representing $42.5 \mathrm{wt} . \%$ of the plant; water corresponds to $57.5 \mathrm{wt} . \%$ and an energy content of around $7400 \mathrm{MJ}$ per ton of cane [58]. The main products of the sugarcane are sugar for the food market, anhydrous ethanol (fuel additive), and hydrated ethanol (non-energy use and use in flex vehicles) [59].

At the same time, the sugar and alcohol sectors are responsible for important environmental impacts, the intensive use of natural resources, and the production of large amounts of waste [60]. This waste corresponds to $30 \%$ of the input amount of raw material, the most significant of which are land, bagasse and straw, soot and ash, filter cake, and vinasse [61].

The bagasse obtained in the production of sugar (and alcohol) is the fibrous material of the cane milling, which consists of fiber vessels, parenchyma, and epithelial cells [62]. It is used for energy generation, in thermal (70\%), mechanical, and electrical $(30 \%)$ forms, and the energy obtained by burning this residue in boilers is sufficient to supply the demand of the production units and also generate exportable surplus for the network national [63]. Additionally considered as solid waste, straw represents between 20 and $30 \%$ of the mass of green cane and is comparable to the energy of bagasse [64]. The percentage of these straw residues, such as leaves and ends, contributes to increasing the amount of biomass available for cogeneration, giving rise not only to obtaining a surplus of electricity for sale to the grid but also to obtaining first- and second-generation biofuels [65].

The sugar and alcohol sector holds one of the largest portions of all renewable energy in the Brazilian energy mix, playing an important role as a supplier of biofuel, and a 
prominent role as a supplier of electricity [66]. The sugarcane crop in Brazil has a huge potential for chemical and thermochemical conversion processes using waste as feedstock to obtain products with high benefits through sustainable processes. In biorefineries, biomass conversion can be integrated to allow the production of a wide range of biomaterials, biofuels, biochemical, and bioenergy [59].

According to a survey carried out in 2015, of the 11 largest biorefineries that use sugar cane as raw material, nine are included in the state of São Paulo. Most use sugarcane bagasse to generate energy and waste, such as vinasse, a filter cake, and ashes as fertilizers in the plantation (Table 2).

To improve the handling and properties of sugarcane bagasse, studies are being carried out on torrefaction. Kanwal et al. [67] roasted at four different temperatures for energy densification and increased the stability for handling and transportation. Gong et al. [68] studied torrefaction at one temperature and showed an improvement in the calorific value, energy density, and the reduction of inorganic elements. Cayhanti et al. [69] studied torrefaction from the environmental and economic aspects' perspective and concluded that some roasted biomasses emit less gas but are not yet economically competitive.

Table 2. Some of the main companies in the sucroenergetic sector in Brazil.

\begin{tabular}{|c|c|c|c|}
\hline Biorefineries & Location & Net Profit (R\$ Million) & Cogeneration \\
\hline Grupo São Martinho [70] & Pradópolis/SP & 288.3 & $\begin{array}{c}\text { Fuel: biomass } \\
\text { Fertilizer: vinasse, filter cake }\end{array}$ \\
\hline Usina Colombo [70] & Ariranha/SP & 118.3 & - \\
\hline $\begin{array}{l}\text { Grupo Santa Terezinha } \\
\text { Participações [71] }\end{array}$ & Maringá/PR & 112.8 & $\begin{array}{l}\text { Fuel: biomass } \\
\text { Fertilizer: vinasse, filter cake, ashes }\end{array}$ \\
\hline Usina Ipiranga [72] & Mococa/SP & 68.9 & $\begin{array}{c}\text { Fuel: biomass } \\
\text { Fertilizer: vinasse, filter cake, ashes } \\
\text { Fuel: biomass }\end{array}$ \\
\hline Usina São Manoel [73] & São Manuel/SP & 61.7 & $\begin{array}{c}\text { Fertilizer: vinasse, filter cake, ashes } \\
\text { Fermentation: second-generation } \\
\text { ethanol }\end{array}$ \\
\hline Usina da Pedra [70] & Serrana/SP & 48.6 & $\begin{array}{l}\text { Fuel: biomass } \\
\text { Fertilizer: vinasse, filter cake, ashes }\end{array}$ \\
\hline $\begin{array}{c}\text { Cia Melhoramentos do Norte } \\
\text { do Paraná [70] }\end{array}$ & Jussara/PR & 38.4 & $\begin{array}{l}\text { Fuel: biomass } \\
\text { Fertilizer: vinasse, filter cake, ashes }\end{array}$ \\
\hline Usina Batatais [74] & Batatais/SP & 30.7 & $\begin{array}{l}\text { Fuel: biomass } \\
\text { Fertilizer: vinasse, filter cake, ashes }\end{array}$ \\
\hline Grupo Balbo [75] & Sertãozinho/SP & 25.3 & $\begin{array}{c}\text { Fuel: biomass } \\
\text { Fertilizer: vinasse, filter cake }\end{array}$ \\
\hline Adecoagro [76] & São Paulo/SP & 17.1 & $\begin{array}{l}\text { Fuel: biomass } \\
\text { Fertilizer: vinasse, filter cake }\end{array}$ \\
\hline Usina São João [77] & Araras/SP & 12.1 & Fuel: biomass \\
\hline
\end{tabular}

Due to its structure, sugarcane bagasse cannot be fermented directly, but there are several alternatives to separate the sugar content from the lignocellulosic structure using enzymatic and/or chemical treatments, like hydrolysis and organosolv [78-80] obtained results from the fermentation of sugarcane bagasse producing acetone, butanol, and ethanol. Guilherme et al. [81] performed tests in a simultaneous process of saccharification and fermentation and were successful, reducing the need for oil and obtaining an ecological process. Salomão et al. [82] studied several enzymes to decrease the cost of the fermentation process and concluded that temperature has a great effect on cellulase production.

The ashes of the boilers from burning sugarcane bagasse have also been utilized. Berenguer et al. [83] studied the addition of these ashes to replace Portland cement and had positive results. Mello et al. [84] used some percentages of biomass ash in self-compacting concrete subjected to high temperatures and concluded that up to $40 \%$ of ash has lower losses in strength than room temperature. Oliveira et al. [85] synthesized the ashes to 
produce low-cost zeolites and showed excellent results in the ion-exchange properties compared to commercial polymeric resins.

Current studies have considered the use of sugarcane bagasse as a source of activated carbon. Jacob et al. [86] studied three types of activated carbon from sugarcane bagasse to decontaminate the water from pesticides and concluded that it is possible to use it. Akinfalabi et al. [87] synthesized a nano-catalyst using activated carbon from sugarcane bagasse to produce biodiesel with palm fatty acid and were successful.

\section{Thermochemical Conversion Routes of Lignocellulosic Biomass}

Several conversion routes, including thermochemical conversion, biotechnological, and physicochemical, have been considered to convert biomass into valuable products [88,89], such as combustion, gasification, hydrothermal liquefaction, pyrolysis, catalytic pyrolysis, and others $[9,90,91]$. These can be directed towards different products and product yields (heat, synthesis and producer gas, bio-oils, and bio-char). The thermal processes available to convert lignocellulosic biomass into energy or chemicals are summarized in Figure 2.

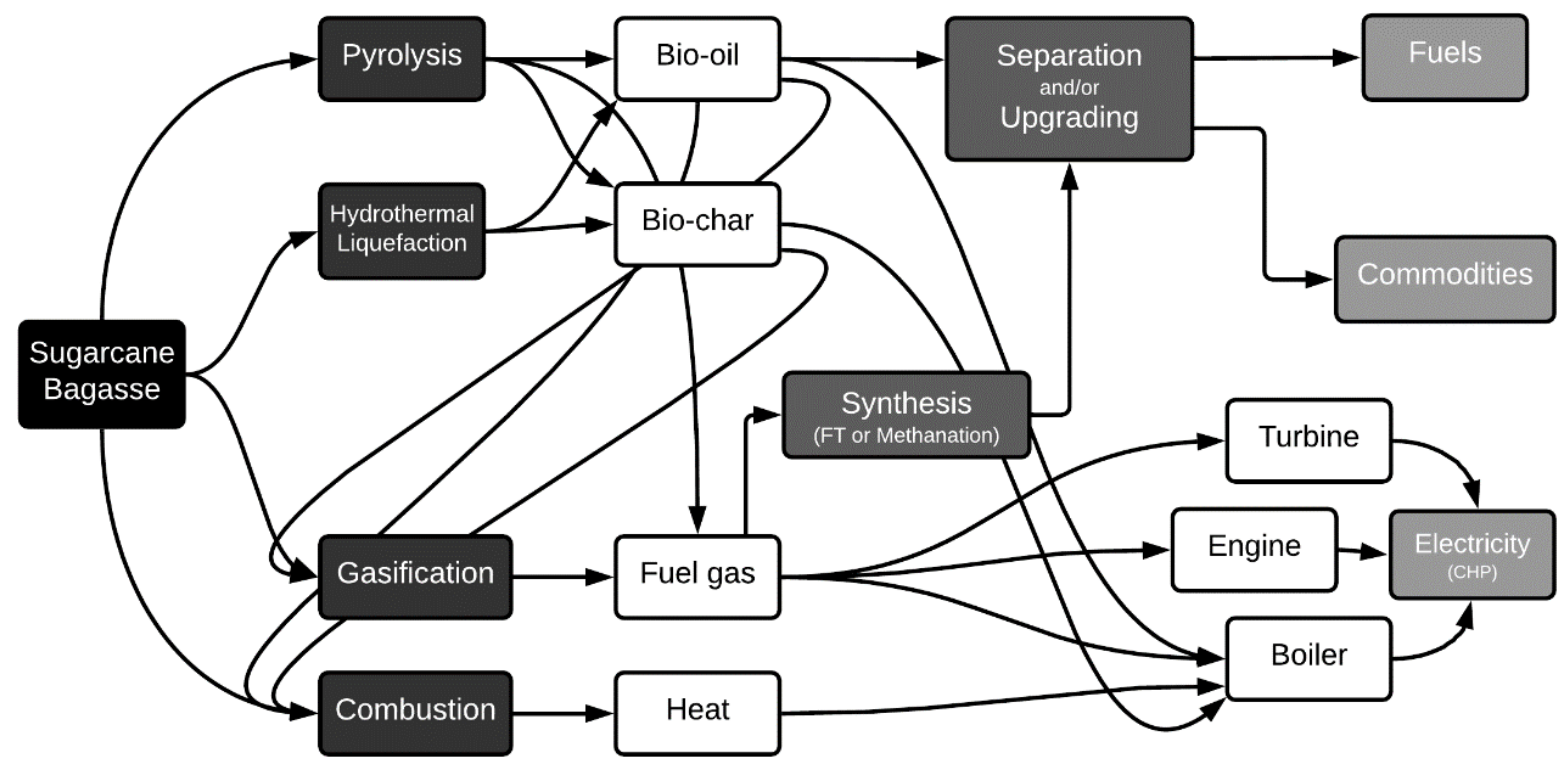

Figure 2. Products of the thermal conversion of lignocellulosic biomass. Adapted with permission from Bridgwater, A.V.V. [92] (2012). Copyright 2012 Copyright Elsevier. CHP = Combined Heat and Power, FT = Fischer-Trospch.

\subsection{Pyrolysis}

Pyrolysis is classified as a thermochemical process of energetic conversion, which occurs in an inert atmosphere, through the application of temperature rising that decomposes macromolecules $[88,93]$. An alternative to the high energy demand of pyrolysis, mostly to achieve and maintain the required operating temperatures, may lay in the process of autothermal pyrolysis, which is achieved by the partially exothermic combustion of the feedstock, through the controlled input of very small partial pressures of oxygen [94].

The pyrolysis conversion has been applied to raw wood for char production used in iron extraction and steel production, already before the industrial age until today. Kerosene was first obtained through the pyrolysis of coal and was widely employed for public illumination. Nowadays, pyrolysis is widely studied and employed for the production of bio-char and liquid fuels [95].

The application of this process yields three products, solid char, and liquid bio-oil, along with a gas phase, the pyrogas. The char phase is rich in carbon, and it retains the vast majority of the inorganic material present on the feedstock, the co-called ash, as well as having a high LHV $[95,96]$. The pyrolysis gas is mostly made up of gases that do not condensate at ambient temperatures, like $\mathrm{CO}, \mathrm{CO}_{2}$, and light alkanes [95]. The bio-oil, its composition, and representation are further explored in Section 4. 
A combination of process variables influences the thermal degradation: feedstock, temperature, residence times of both gas and solid under pyrolysis conditions, pressure, heat transfer, reactor design, sweeping gas use, and product recovery systems, among others $[12,91,97]$. Among these, heat transfer is regarded as the most relevant factor, as it governs the selection of the reactor type, heating method, and product recovery. Thus, a pyrolysis process is often classified based on how fast this heat transfer occurs. The most common classifications are presented in Table 3, while conventional methods of supplying heat to the reaction can be observed in Figure 3.

The heat demand associated with reactor heating, endothermic demand, or feedstock conditioning is often met with the combustion of pyrolysis by-products, mainly the gas and a fraction of the cokes [95]. Such a situation was calculated for the case of the bioliq ${ }^{\circledR}$ pyrolysis plant [98].

Table 3. Different pyrolysis classifications based on the heat transfer method $[16,92,95,99]$.

\begin{tabular}{|c|c|c|c|c|}
\hline & Heating Rate & Temperature & $\begin{array}{c}\text { Solid Residence } \\
\text { Time }\end{array}$ & $\begin{array}{c}\text { Vapor Residence } \\
\text { Time }\end{array}$ \\
\hline Slow pyrolysis & $\begin{array}{c}\text { Low } \\
\left(<1^{\circ} \mathrm{C} / \mathrm{s}\right)\end{array}$ & $\begin{array}{c}\text { Low } \\
\left(>400^{\circ} \mathrm{C}\right)\end{array}$ & $\begin{array}{l}\text { Long or very long } \\
\text { (minutes to days) }\end{array}$ & $\begin{array}{c}\text { Long } \\
\text { (>seconds) }\end{array}$ \\
\hline $\begin{array}{c}\text { Intermediate } \\
\text { pyrolysis }\end{array}$ & Moderate & Moderate & $\begin{array}{c}\text { Long } \\
\text { (minutes) }\end{array}$ & $\begin{array}{c}\text { Moderate } \\
\text { (some seconds) }\end{array}$ \\
\hline Fast pyrolysis & $\begin{array}{l}\text { Very high } \\
\left(>100^{\circ} \mathrm{C} / \mathrm{s}\right)\end{array}$ & $\begin{array}{c}\text { Moderate or } \\
\text { High }\left(425-600^{\circ} \mathrm{C}\right)\end{array}$ & $\begin{array}{c}\text { Short (a few } \\
\text { seconds or less) }\end{array}$ & $\begin{array}{l}\text { Very short } \\
\text { (<seconds) }\end{array}$ \\
\hline
\end{tabular}

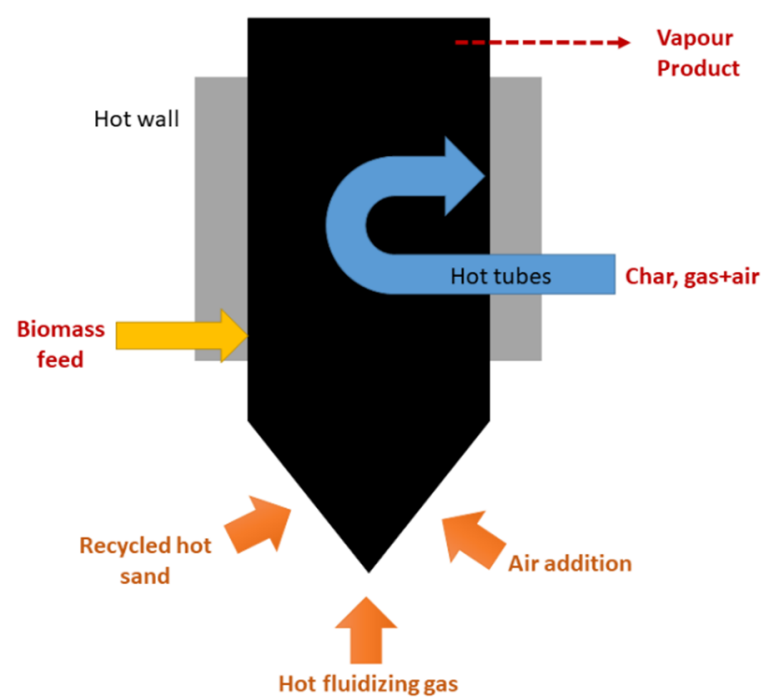

Figure 3. Methods of heating commonly employed. Adapted [100] with permission from IEA Bioenergy. Copyright 2021 IEA Bioenergy.

Fast pyrolysis processes often report high liquid yields, up to $75 \mathrm{wt} \% \mathrm{db}$., along with sensitively equal yields in gases and char, which are considered by-products. In this kind of process, heat transfer must occur extremely rapidly within the individual feedstock particles; hence, the feedstock is usually supplied ground to the order of millimeters. Additionally, to make the heat transfer fast and efficient, heat carrier systems are often employed [13]. As the bio-oil (Fast Pyrolysis Bio-oil, FPBO) is the main target, the feedstock's moisture content (MC) is usually kept below $10 \%$ wt. to minimize the amount of water in the liquid [92]. Above $550{ }^{\circ} \mathrm{C}$, the formation of non-condensable gases in the products is favored [12]. To reach liquid yields, over $75 \% \mathrm{wt}$. $\mathrm{db}$., a process named flash pyrolysis is in development, featuring residence times that are kept in the range of 30-1500 ms [95]. 
Other relevant processes that can be considered comparable to pyrolysis are torrefaction and pyrolytic gasification (Figure 4). Both take part in the absence of oxygen, but the former happens at temperatures under $300{ }^{\circ} \mathrm{C}$, and a residence time of around $2.5 \mathrm{~min}$, thus targeting the production of carbon-rich solid fuels [101]. The latter performs gasification in two stages, employing steam as a fluidizing agent, aiming for the production of a biosyngas with a heating value between 1 and $20 \mathrm{MJ} / \mathrm{m}^{3}$, mainly owing to a high methane fraction [88].

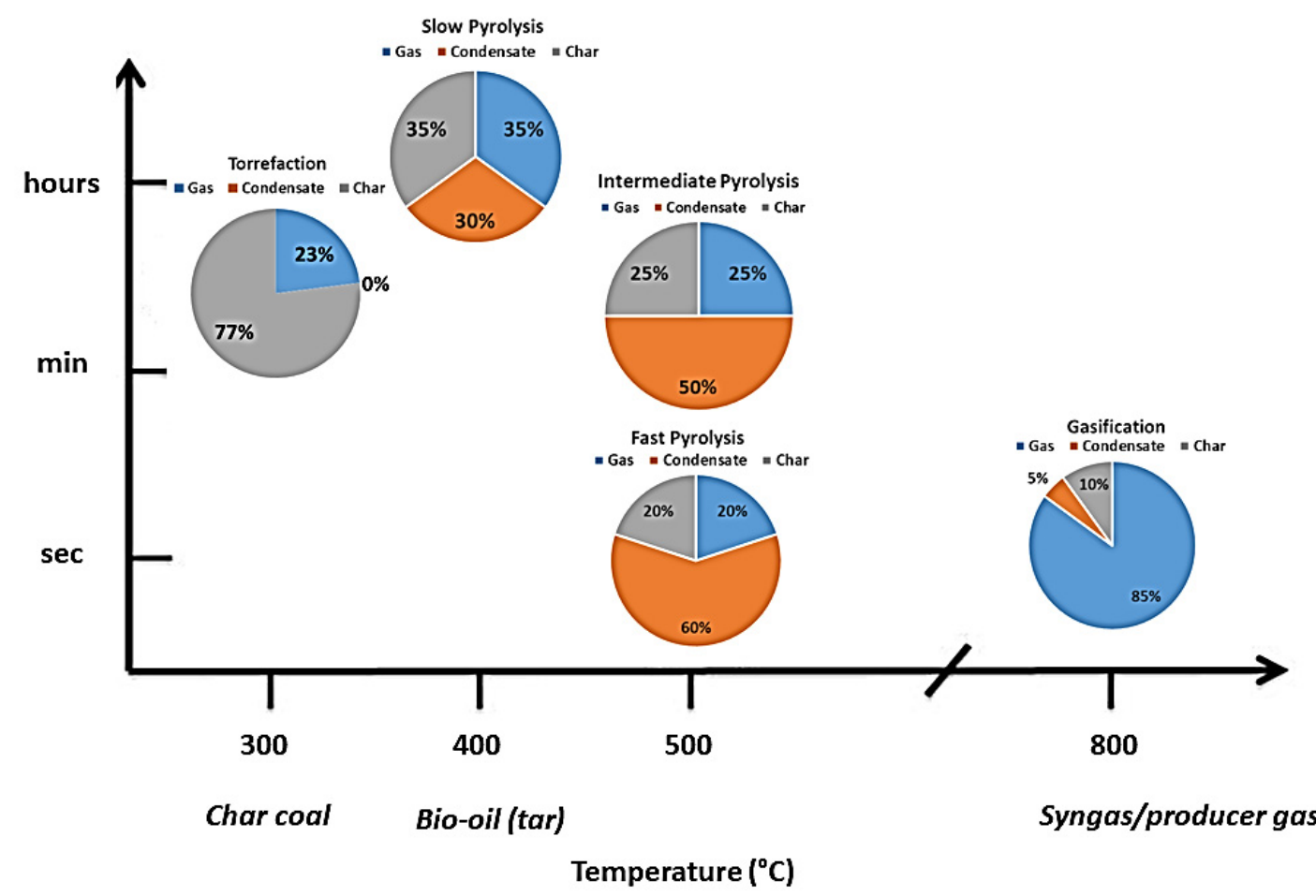

Figure 4. Distribution of char, condensate, and gas products for different types of pyrolysis. Adapted with permission from Dahmen [102] (2019). Copyright 2019 Copyright KIT.

A great variety of vegetable biomasses has already been submitted to fast pyrolysis to determine the product distribution (liquid, gas, and char), with a growing focus on agricultural residua, including wheat straw, eucalyptus, barley straw, olive pits, nutshells, Miscanthus, sorghum, etc. $[9,97,103]$. On the other hand, wood biomass has historically been the main feedstock for fast pyrolysis due to higher reproducibility and commercial interest [9]. These tests in different scales have resulted in considerable differences in product distribution. Presently, research efforts have focused on the valorization of other types of residua, namely sewage, which is often made difficult by an ash-rich composition, leading to catalytic effects that lead to lower production of liquid, as well as slagging during operation [104].

\subsection{Factors Affecting the Behavior of Pyrolysis \\ 3.2.1. Degradation Reactions and Their Kinetics}

According to Kan et al. [91], the pyrolytic decomposition mechanism is very complex because of a high number of competitive reactions (dehydration, decarboxylation, isomerization, depolymerization, and charring) taking place. A common approach assumes that the degradation of the different polymers that comprise the cell wall structure takes place in parallel decomposition networks for each lignocellulosic polymer (hemicellulose, cellulose, lignin). Different authors disagree slightly at which temperatures the degradation of the different components occurs, and two proposed ranges are shown in Table 4. 
Table 4. Thermal decomposition temperature ranges $\left({ }^{\circ} \mathrm{C}\right)$ for lignocellulosic components, according to two different sources. Adapted with permission from Di Blasi et al. (2008), Yang et al. (2007). Copyright 2007, 2008 Copyright Elsevier [105,106].

\begin{tabular}{ccc}
\hline Component & Di Blasi & Yang \\
\hline Hemicellulose & $225-325$ & $220-315$ \\
Cellulose & $325-375$ & $315-400$ \\
Lignin & $250-500$ & Up to 900 \\
\hline
\end{tabular}

The decomposition of hemicellulose involves the breakage of the glycoside bond that holds the xylan matrix, and the subsequent production of sugars and pyrans, which further degrade into low-molecular-weight compounds. Common products observed are acetic and propionic acids, as well as non-aromatic ketones, such as hydroxypropanone, and furfural $[9,107]$.

Due to the economic interest and availability, the degradation of cellulose has been a widely studied topic [108]. It involves the depolymerization of cellulose into glucose via retro-aldol condensation, followed by $\beta$-elimination with the production of levoglucosan. The latter is commonly found in fast pyrolysis oils in relative abundance, as further ring fragmentation is promoted by secondary gas-phase pyrolysis, which can be hindered by keeping low vapor residence times during the reaction. Additional commonly reported are anhydrosugars other than levoglucosan, as well as ring fragmentation products, such as hydroxyacetaldehyde, acetic and propionic acids, 5-hydroxymethylfurfural (HMF), and furfural [107].

Lignin in high concentrations in a feedstock has been linked to a more significant formation of char $[9,91,97,109]$. The degradation of lignin seems to follow two parallel principles: the thermal cleavage of inter-unit linkages and charring reactions. The former induces the formation of phenols, guaiacols (methoxyphenols), and syringols (dimethoxyphenols), which are thought to stem directly from the ratios between p-coumaryl, sinapyl, and coniferyl alcohol units in the lignin fraction. The presence of side-chains on the lignin matrix provokes the formation of light oxygenates, like acetic acid [107].

\subsubsection{Influence of the Feedstock Properties}

Various kinds of pyrolysis reactors have been developed, in which the design and optimization require a deep comprehension of the reaction and transport phenomena participating in the degradation of the solid feedstock. One area of direct influence that requires further research is the meaning of both the shape and size of the feedstock particles on the final product distribution [110].

It is established that setups featuring very small particles and very low vapor residence times lead to high bio-oil yields, by mitigating the incidence of secondary reactions [92,111]. Wang et al. [112] demonstrated that a varying diameter on wood cylinders has a secondary effect on the liquid formation, but thicker cylinders led to higher water production. Shen et al. [113] proposed that mechanical particle size reduction (shredding, milling) leads to higher oil yields due to disruption of the internal particle structure, leveling out after a specific particle size. The fact is corroborated by Salehi et al. [114], who noticed a drop of $10 \%$ in the bio-oil yield when expanding the sieve fraction from $<0.59 \mathrm{~mm}$ to $0.59-1 \mathrm{~mm}$ and kept constant for higher fractions. Decreases in coal yield with smaller particle sizes were found by Demirbaş [115] using olive husks and Luangkiattikhun et al. [116] using oil palm solid waste, while Pütün et al. [117] found no correlation for sunflower pressed bagasse, in contrast to coal and oil shales.

The heating rate of the biomass particles is of utmost importance for the pyrolysis process, impacting process control, product yields, and product quality [110,111,118-120]. Kersten et al. [118] affirm that the individual particle decomposition is controlled by external heat transfer and thermal diffusivity for wood particles larger than $1 \mathrm{~mm}$, where this decomposition takes place very close to the reactor temperature for smaller particles, 
being, therefore, kinetics driven, an opinion shared with other authors [121-124]. Funazukuri et al. [125] estimated a heat transfer rate of $\sim 100,000 \mathrm{~K} / \mathrm{s}$ for cellulose particles of $0.06 \mathrm{~mm}$ vs. $\sim 1000 \mathrm{~K} / \mathrm{min}$ for $0.6 \mathrm{~mm}$, using microfluidized bed flash pyrolysis.

Another critical factor that determines the product distribution is the residence time of the depolymerized biomass amidst the reacting particle, whether in gas/vapor (vaporization/sublimation, sweeping) or liquid/solid states (physical entrainment to form aerosols) [113,126,127]. Haas et al. [127] performed real-time microscopic analyses of poplar wood pyrolysis of single particles, where liquid droplets of partially depolymerized material were formed throughout the heating process. These either escaped via structural channels inherent to the biomass (anisotropic vapor flow) or were trapped within the particle, eventually cross-linking into chars. The authors also found that these droplets mostly originate on the middle lamella of the wood material, where the majority of the lignin fraction is situated. Teixeira et al. [128] employed a fast-speed camera to prove that the collapse of a bubble of liquid intermediates is the primary mechanism in the formation of jets, which break down to form aerosols.

Westerhof et al. [110] explored the significance of both the particle geometry and microstructure on the fluidized bed fast pyrolysis of beech wood. Both wood cylinders $(2-14 \mathrm{~mm})$ with longitudinal channels, as well as milled $(<0.08-2.4 \mathrm{~mm})$ particles were employed, with the latter being free or contained within metal cylinders of different diameters with longitudinal channels, either with a solid wall (anisotropic vapor flow) or different wire mesh sizes (isotropic vapor flow). Studies with uncontained milled wood, composed only of cell walls, at rising sieve sizes indicate a decline of organic liquid yield due to a diminished release of levoglucosan and water-insoluble substances, and an increase of water, char, and gas production. Larger particles, either pellets or filled metal cylinders, showed minimal variation in yields and behavior, as the release of vapor is not impacted by the microstructure and the pattern of vapor outflow, rather essentially by internal heat transfer limitations.

Based on the findings by Westerhof et al. [110], Zhou et al. [129] studied the effect of the particle size on the production and removal of water-insoluble oil (henceforth named 'pyrolytic lignin'-PL). For widening biomass particle sizes, the yield of PL diminishes greatly until a diameter of $3 \mathrm{~mm}$, after which a negligible variation is seen. For a larger particle size, the authors propose a mechanism in which PL jets contact other sections of the cell wall and lead to a higher formation of char, due to higher heat transfer limitations. Smaller particle sizes seem to lead to higher yields of methoxyl groups (guaiacols and syringols), as indicated by ${ }^{1} \mathrm{H}-\mathrm{NMR}$ and Py-GC/MS results, which are highly diminished in higher particle size samples.

Bridgeman et al. [130] showed that the inorganic content of the smaller-sized particles $(<90 \mu \mathrm{m})$ was approximately double that of larger particles. The authors proposed that size reduction, in its different forms, does not distribute the mineral composition of the biomass uniformly, causing uneven dissemination of both organic and inorganic fractions into different sized particles, with distinct properties and thermal degradation behaviors.

The chemical composition of biomass plays a significant role during pyrolysis. Inorganics present in the lignocellulosic matrix, including calcium and magnesium, but strongly potassium and sodium compounds, can have a catalytic effect on lignocellulosic degradation. Among other effects, this so-called ash content promotes cracking secondary pyrolysis, shrinking the organic liquid yield and augmenting the water content, leading to lower storage stability of the produced oil, as well as increasing char and gas formation $[9,12,13,97,131]$. The presence of alkali earths in solution in the bio-oil may negatively affect the use of upgrading measures, due to catalyst poisoning [131]. Apart from the aforementioned impact on bio-oil composition and yield, this ash accumulates in the accrued char fraction and may preclude its downstream valorization.

Biomass washing, using water or acid solutions, leads to a reversal of the adverse effects described in the previous paragraph. Krutof and Humboldt [131] compiled several of the most relevant results on this topic. However, washing leads to the formation of 
a spent effluent with a high metal content, therefore requiring special attention when considering large-scale materializations.

\subsubsection{Feedstock Moisture Content and Vapor Residence Time}

The moisture content of a lignocellulosic feedstock will primarily impact the water content of the condensate (bio-oil), leading to phase separation in the liquid phase for high enough water contents and lowering the energy efficiency of the process $[91,97,98]$. Accordingly, biomass is usually utilized in fast pyrolysis if its moisture content is below 10 wt.\% [92], a factor that can be achieved via drying [98].

Fonseca et al. [98] studied the effect of the feedstock moisture content and the throughput of sweeping gas $\left(\mathrm{N}_{2}\right)$ on the product distribution of fast pyrolysis of wheat straw (continuous operation, $10 \mathrm{~kg} / \mathrm{h}$ ) (Figure 5). One can observe the effect of the moisture content (MC) and vapor residence time (low sweeping $=1.3 \mathrm{Nm}^{3} \mathrm{~h}^{-1}$, high sweeping $=3.2 \mathrm{Nm}^{3} \mathrm{~h}^{-1}$ ) in the functional group distribution (based on GC/MS analyses, discounting undetected fraction) of the organic condensate obtained at the Python PDU, KIT Campus Nord, Karlsruhe, Germany. The presence of water vapor, mostly from drying of the biomass, further dilutes the mixture and promotes thermal cracking reactions. Aldehydes are known for being especially vulnerable to this situation, explaining the trend [132]. On the other hand, the lowering of the vapor residence time (due to the increased sweeping rate in the reaction) within the reactor can lead to a more significant recovery of higher molecular weight compounds (furans, guaiacols, syringols), which would otherwise undergo cracking, leading to higher condensate production [98].

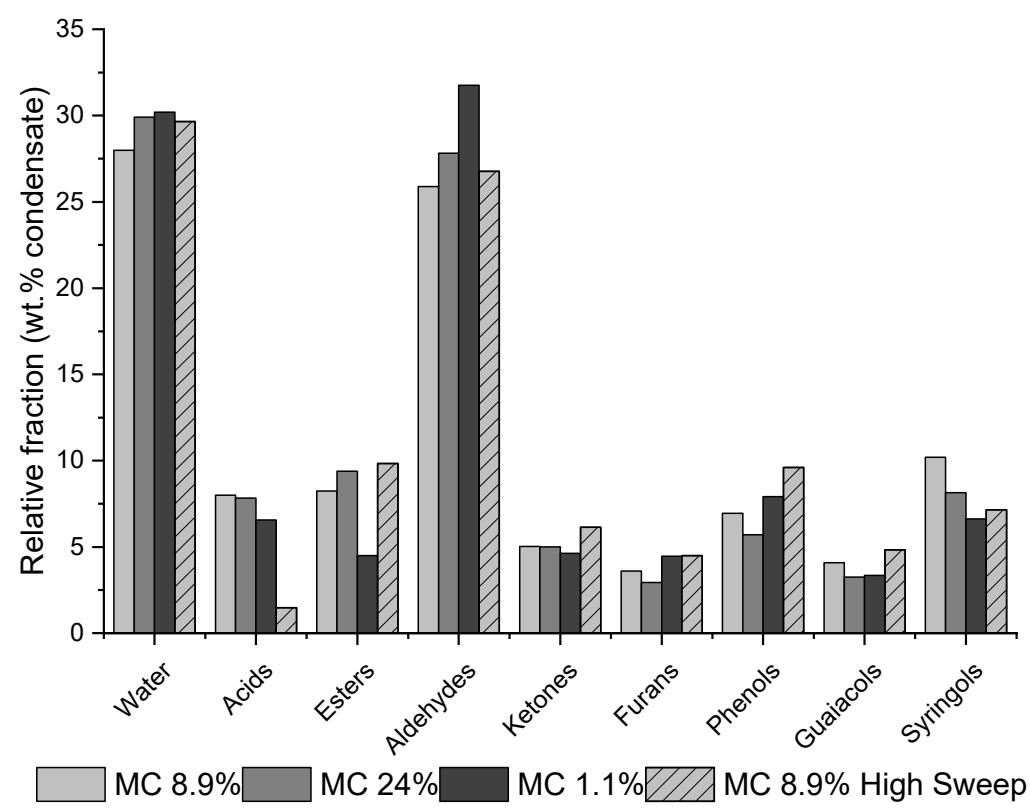

Figure 5. Functional group distribution of FPBO of wheat straw at different feedstock moisture contents (MCs). Results were normalized to account for the presence of water and non-detectable heavy compounds. Adapted with permission from Fonseca, F. G. et al. [98] (2019). Copyright 2019 Copyright Elsevier.

Kim et al. [133] focused on the influence of the volume of sweeping gas used in the reactor on the oil yields and compositions of a three-condenser system $\left(85,45,10^{\circ} \mathrm{C}\right)$. The authors reported lower water contents and higher viscosities for condensates produced at higher volumes of sweeping gas. The recovery of glycolaldehyde, acetic acid, and guaiacol, among others, seems to increase at larger volumes of sweeping gas, especially in the intermediate condensate. 


\subsubsection{Effect of Condensation and Aging}

After exiting the reactor, the produced vapors, still at a very high temperature, must be quickly separated from the solids, and cooled down, to further diminish the occurrence of secondary reactions. An overview of already implemented condensation concepts was compiled by Papari and Hawboldt [134].

In an industrial context, lab-scale apparatuses, such as cold traps, are not viable, due to the energetic requirements of maintaining static cooling. Hence, condensation of vapors is achieved through the use of quenching systems that consist of showering the hot vapors with a relatively cold liquid in significant excess, and electrostatic precipitators to promote aggregation of liquid droplets, especially relevant at higher gas flow rates [93]. The relationship between the water content and quenching temperature was already the subject of several studies $[135,136]$.

When quenching is performed using cooled-down bio-oil (assuming steady-state operation, during which any starting quenching medium used for operation start-up is assumed to have been wholly replaced) as the quenching medium, the latter is kept at the desired quenching temperatures during extensive periods. In the context of a publication by Schmitt et al. [137], which employs nickel-based catalysts for the improvement of the properties of sugar cane bagasse FPBO, the effect of this maintenance at high temperatures (also known as 'aging') was compared to results from Py-GM/MS, as shown in Figure 6.

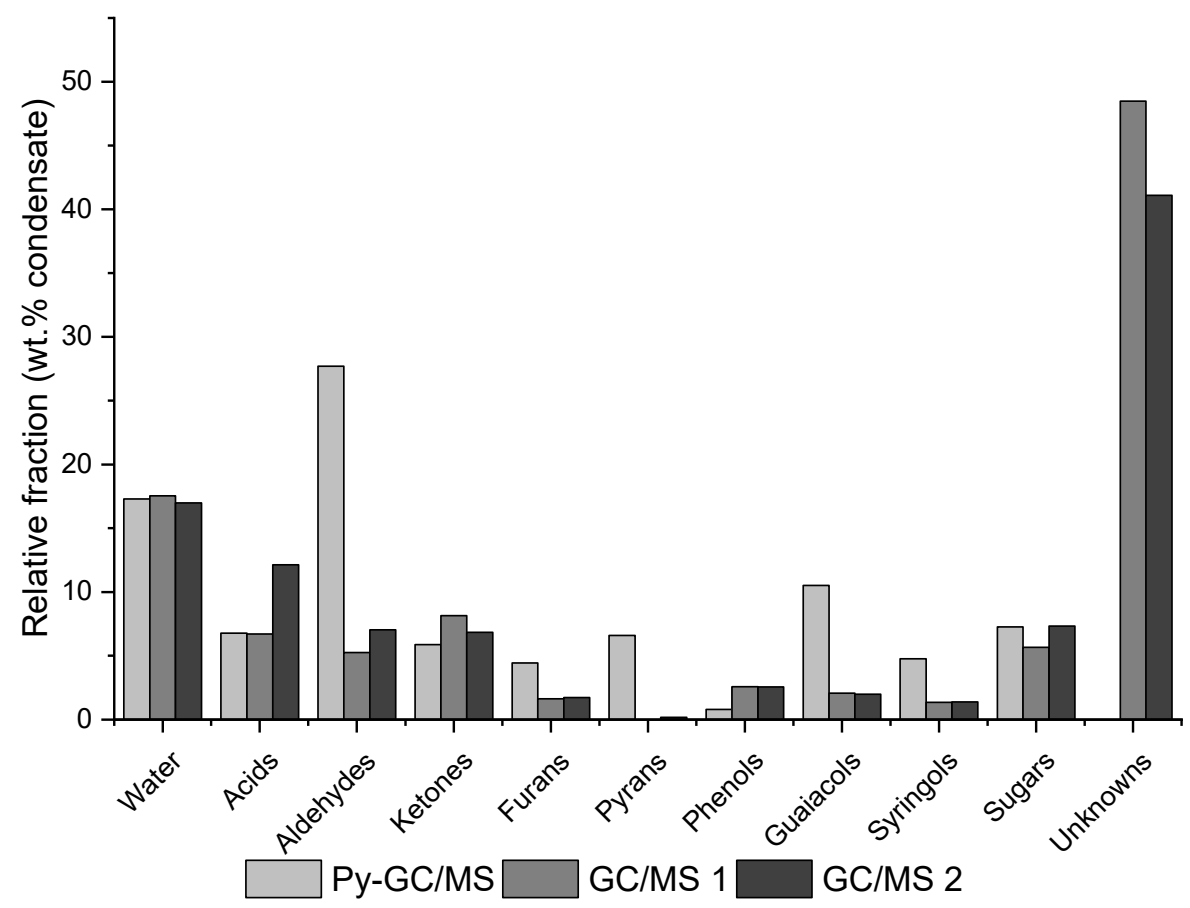

Figure 6. Comparison of Py-GC/MS and conventional GC-MS separated by some months. Results were normalized to account for the presence of water and non-detectable heavy compounds. Adapted with permission from Schmitt et al. [137] (2020). Copyright 2020 Copyright Elsevier.

In Figure 6, one can observe the effect of the analysis method and the timespan between gathering and analysis. While differences in the GC/MS results can be expected for duplicates, or even between trials employing the same experimental conditions, a clear trend can be observed between immediate analysis of the vapors, and that of a stored condensate. Organic acids are expected to be mostly stable during homogeneous secondary pyrolysis reactions and are also expected to be formed by these same reactions, explaining their increased yield. At the same time, the molecular weight (MW) of sugars may be above the cutoff of the Py-GC/MS method, as these are relatively stable compounds often quantified in conventional fast pyrolysis condensates. Aldehydes and pyrans are known to 
be readily degraded at pyrolysis temperatures, hence the considerable diminution in yield when comparing the two methods [132].

\subsubsection{Reactor Design}

Different reaction designs have been considered for pyrolysis of biomass. A detailed description of some of these design in presented in the sequence.

- Entrained flow reactors

Entrained flow reactors are vertical tube reactors perfused by a hot gas stream to maintain the temperature, into which a mixture of heat carrier and particulate feedstock is introduced, usually laterally. It is a pyrolysis application of a well-researched method, meaning that technical, control, and up-scaling are simple. While high gas flow rates ensure minimal vapor residence time, they lead to hefty operating costs due to the heating and cooling of masses of gas and require a large condensation system to deal with such volumes $[88,138,139]$.

- Stationary fluidized bed reactors

Similar to the entrained flow reactors, fluidized flow reactors feature an otherwise fixed bed of heat carrier, such as sand, that is heated and fluidized by hot gas but uses low velocities or solid barriers to avoid entrainment. Biomass is introduced directly into the solid bed, and the solid product helps to regenerate the sand bed, although attention must be paid to the accumulation of ash. Vapors are removed and readily condensed, and the resulting non-condensable gas is used either as a fluidizing gas or burned to provide heat to the fluidized bed $[138,139]$.

The process is characterized by a solid technical background and ease of scale-up, plus excellent heat transfer and distribution, and low vapor residence times. Adjusting the flow rate of fluidization gas permits easy control of the solid residence time. However, similarly to the entrained flow reactors mentioned before, it requires the heating and manipulation of high amounts of gas. Although the ash content of the feedstock can help replenish solid loss in the bed, the amount of unburned coke must be accounted for, due to both of these having a catalytic effect during pyrolysis. Heat transfer and fluidization quality are also dependent on the particle size of the bed, which is prone to sintering and baking over time under high temperatures.

- Circulating fluidized bed reactors

Similar to the stationary bed materialization, circulating fluidized bed reactors (Figure 7) make use of high gas flow rates to fluidize the bed to such an extent that it overflows. The feedstock is introduced directly into the hot bed. The overflowing bed mixed with cokes is spent in a secondary vessel by mixture with air mixed with air, and the hot bed material is reintroduced into the primary system, in a process akin to the FCC (fluidized catalytic cracking) one, widely employed in oil refineries for the production of light and medium distillates. Pyrolysis gas is either discarded or recycled as fluidizing gas [140].

Advantages and disadvantages of this system are similar to the stationary bed. Again, while scale-up and operation are technically simple, and low vapor residence times lead to good liquid yields, the manipulation of a high amount of hot gas is energetically disadvantageous. Other technical issues stem from the mechanical abrasion stemming from the bed material, as well as the accumulation of ash in the solid bed, which may lead to a greater incidence of secondary reactions.

- $\quad$ Screw reactors

Screw reactors (Figure 8), also named augers, are very often used for continuous processing, providing axial conveying, and promoting radial mixing along the reactor. This type of equipment has been used since the beginning of the 20th century for conveying and drying solids, and the first known reference to pyrolysis of coal using auger reactors dates to 1969. It has also met application in the thermal cracking of refinery residues, or the processing of shale oil $[138,141]$. 


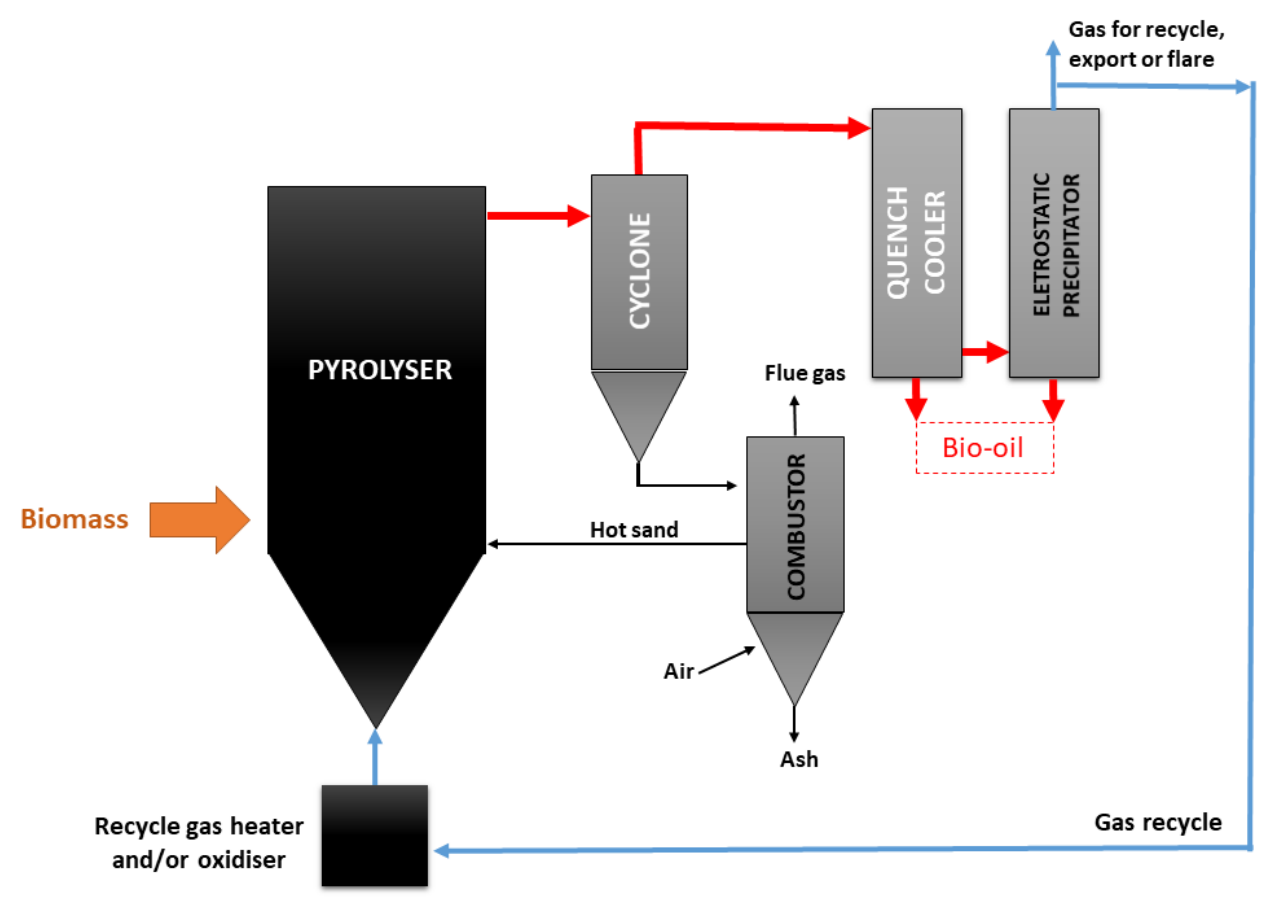

Figure 7. Scheme of circulating fluidized bed pyrolysis employing an electrostatic precipitator. Adapted with permission from IEA Bioenergy [100]. Copyright 2021 Copyright IEA Bioenergy.

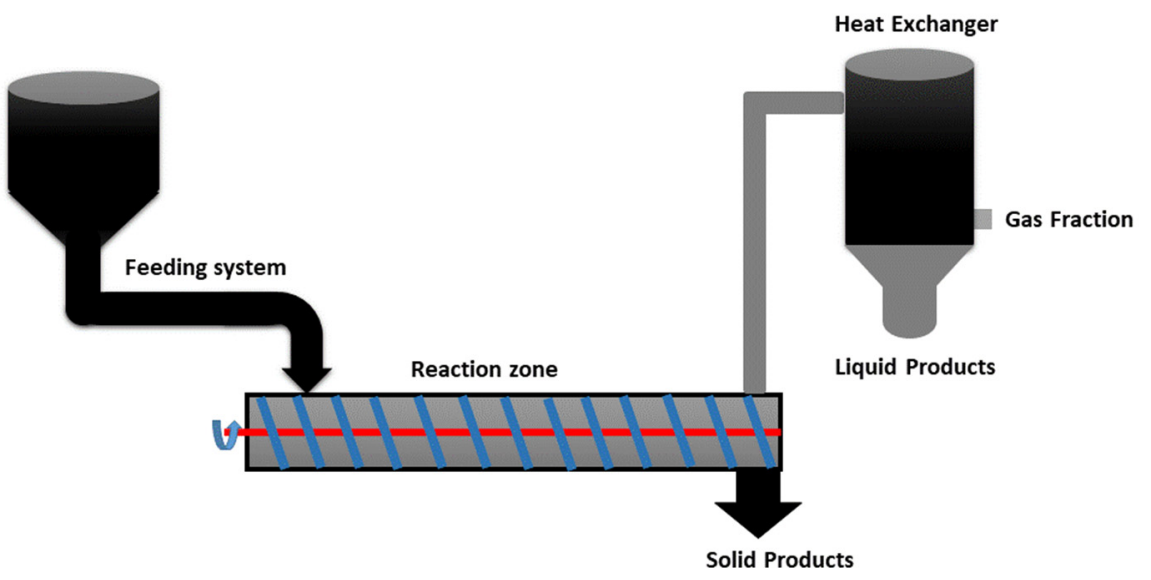

Figure 8. Scheme of a screw reactor for the pyrolysis of solid feedstocks. Adapted with permission from Campuzano, F. et al. [142] (2019). Copyright 2020 Copyright Elsevier.

Often, instead of a single screw, two articulated concordant screws are employed. Heat carriers supply the majority of the heating to ensure the desired heating rates, although external heating is also common to minimize fluctuations and ease process control. The vapors exiting the reactor are subjected to cooling, producing the liquid and gas products [143].

Some advantages for the use of such types of reactors include feedstock handling and operation, as well as a compact design, which allows reactors of this type to be easily transportable. Such a compact design would enable the installation of small-scale units close to biomass/residua production sites, or even mobile units. Auger reactors are relatively flexible regarding the dimensions of the feedstock, and the moment and forceful contact between the solids ensures the brittle char is crushed finely. Some disadvantages stem from the mechanical movement of the screw shafts and the abrasiveness of the materials conveyed within [138,144]. 


\section{- $\quad$ Rotating cone reactors}

In this type of materialization, biomass is introduced simultaneously with a heat carrier into a revolving cone. The said cone features a system, which propels solids up its wall. The solids take a spiral orbit due to friction and centrifugal force and are collected under the cone, while the gases and the entrained fine cokes are separated conventionally. Pyrolysis gas and mixed-in coke are burned to heat the heat carrier that is returned to the top. This process shows a great advantage of minimal vapor residence times and the lack of requirement of fluidization gas. However, reliance on moving parts is a technical disadvantage, and the wear and tear are exacerbated by the use of solid heat carriers that cause abrasion. Due to the lack of fluidization, the process is limited in terms of the feedstock particle size [92].

\section{- $\quad$ Ablative pyrolysis}

A novel process named ablative pyrolysis (Figure 9) has been developed recently. In this process, biomass is pushed against a hot rotating surface, which promotes rapid heat transfer, leading to fast degradation and vaporization. It allows for the use of feedstocks of a broader range of sizes and shapes, which are usually disregarded during conventional pyrolysis processes, avoiding the considerable energy costs associated with grinding/shredding. The high heat transfer rates allow for very fast vaporization of the degradation product, decreasing the requirements for a sweeping gas, and the mechanical force fosters an efficient removal of the solid product from the reactor site. Due to the nature of the process, no heat carrier is used, allowing for a more effortless mass balance, process separation, and maintenance of the plant $[145,146]$. However, the equipment features a series of parts that are simultaneously heated and moving, as well as heat transfer issues and scale-up problems, as the heat demands and size demands are proportional to the amount of material being processed.

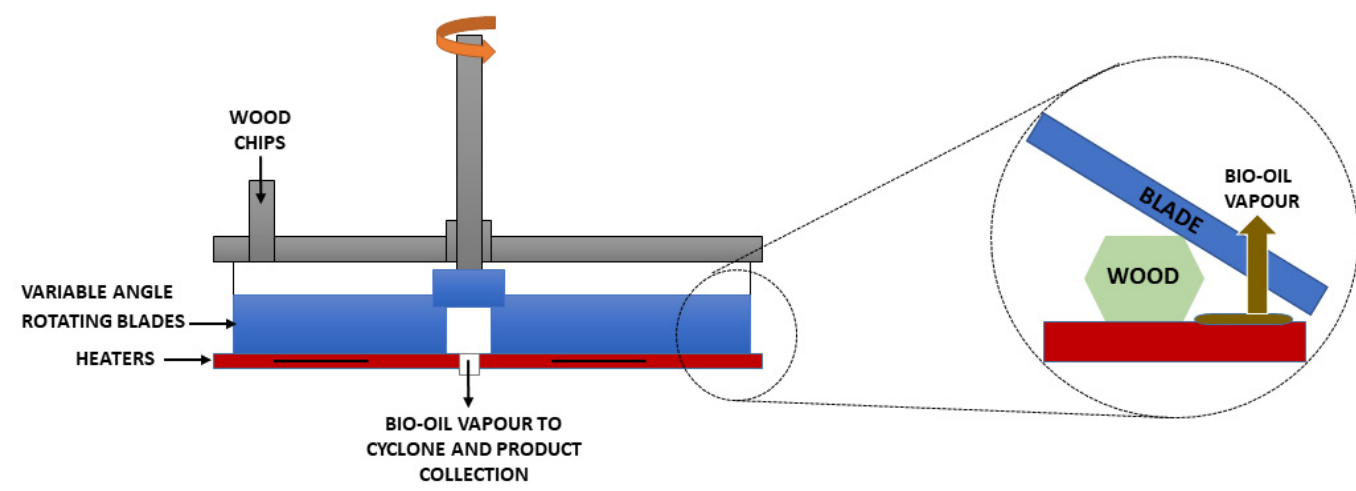

Figure 9. Scheme of rotating disk ablative pyrolysis. Adapted with permission from IEA Bioenergy [100]. Copyright 2021 Copyright IEA Bioenergy.

- Vacuum reactors

While not conventionally a fast pyrolysis system, as heating takes place relatively slowly, a slight vacuum $(-15 \mathrm{kPa})$ is applied to the system to ensure the swift removal of the pyrolysis vapor, not requiring gas fluidization or sweeping. As the biomass is conveyed horizontally, and no sweeping is applied, the fine cokes are not entrained and are quickly recovered without requiring separation systems. The process can accept bigger particle sizes compared to fluidized beds that typically require very small grinds [138].

- Vortex reactors

In a vortex reactor, hot gas or steam is fed tangentially to a feedstock input. The flow conditions and the presence of fixtures and surface modifications on the cyclone cause the particles to impact the heated reactor walls and spiral down while decomposing. The principle is similar to ablative pyrolysis, in the sense that impact and abrasion are an important part of the vaporization of material from the feedstock particles. While the 
technology presents fewer limitations to particle size than conventional methods, and the design allows for constant recycling of particles to ensure complete degradation, the very high fluidization gas and indirect heating make it economically unfeasible, and scale-up is difficult [138,139].

\section{- $\quad$ Rotating kiln reactors}

Kilns have been operated for centuries, and are suitable for processes requiring both heat and high miscibility between phases. Units range from small-scale ovens for the drying of cereal, leaves, or timber, for longer storage times and better fuel properties; to very large-scale units, such as the production of clinker at $1450{ }^{\circ} \mathrm{C}$ on rotary kilns during the production of Portland cement.

Pyrolysis for the production of biochar and heat often makes use of this kind of system, due to simple scalability, versatility (in regards to feedstock), and ease of operation. The diverse uses of biochar vary throughout different communities and available raw materials. In Brazil, biochar is an essential component of terra preta do indio (also known as Amazonian dark earth), which is used to facilitate agriculture in deforested lands, mainly in the Amazon Basin, due to the low fertility of the reclaimed soils [147].

Small/medium-scale (10 kg-10 Ton/10 h of operation) units operate using the "flame cap" technology, in which solid fuel is fed to a kiln (rotating or not), which is currently fired. The intense heat stemming from the combustion promotes the volatilization of the fuel, creating an area of pyrolysis just below the burning layer, which transforms the material into biochar that is collected at the bottom [148]. Non-governmental organizations, namely WarmHeart Worldwide [149] and the Juntos NFP [150], work on the dissemination of flamecap kiln technologies for impoverished communities to enable self-sustainability [148].

\subsection{Research Facilities and Large-Scale Materializations}

Apart from the reactor, a fast pyrolysis system includes biomass handling and preprocessing, condensation and product collection, and, whenever relevant, upgrading, or product processing [151].

Despite representing a relatively minor fraction of the total capital cost of a whole system (according to Meier et al. [151]), the majority of the R\&D in the field of fast pyrolysis has been dedicated to reactor configurations and feedstock testing, and only more recently has focus switched to process control and improvement of condensation systems. The type of reactors most often employed for fast pyrolysis is fluidized (fixed, circulating, transported) beds and variants, due to facilitating heat transfer, vapor collection, and heat carrier re-heating [152]. Processes in which a heat carrier is circulated and externally heated can be considered as circulating bed systems. In these processes, the residence time of the solids and vapors is minimized to avoid secondary reactions, as the char and ash are catalytically active [151], maximizing the extraction of condensable volatiles from the system [92]. For this purpose, considerable flow rates of carrier gas are often used to keep the vapor residence time under $2 \mathrm{~s}$, while aiding with keeping the system free of molecular oxygen; this factor also leads to gas dilution and further lowers its heating value.

Four in-depth reviews of fast pyrolysis research and materialization throughout the world were published by Bridgwater et al. [92], Venderbosch and Prins [153], Maier et al. [151], and Garcia-Nunez et al. [154]. Oasmaa and Peacocke [155] also reviewed the state-of-the-art for pyrolysis liquid formation as of 2010. PyroWiki [156], a Wikipedia-style encyclopedia maintained by experts of fast pyrolysis, keeps a listing of commercial-scale throughout the world. The IEA Bioenergy consortium [100], in their Task 34 website, also offers a small introduction to diverse types of reactors, including explanatory schematics.

Listed in Table 5 is a non-extensive list of installed research pyrolysis units and in Table 6 a list of larger-scale units. 
Table 5. List of research pyrolysis units.

\begin{tabular}{|c|c|c|c|}
\hline Location & Type & Capacity & Reference \\
\hline Aston University, UK & Ablative & $20 \mathrm{~kg} / \mathrm{h}$ & [92] \\
\hline Aston University, UK & Ablative & $2 \mathrm{~kg} / \mathrm{h}$ dry & {$[157]$} \\
\hline BBC, Canada & Ablative & $10-25 \mathrm{~kg} / \mathrm{h}$ & {$[154]$} \\
\hline DTU, Denmark & Ablative & $1.5 \mathrm{~kg} / \mathrm{h}$ & [92] \\
\hline Institute of Engineering Thermophysics, Ukraine & Ablative & $15 \mathrm{~kg} / \mathrm{h}$ & [92] \\
\hline Latvian State Institute, Latvia & Ablative & $150 \mathrm{~g} / \mathrm{h}$ & [92] \\
\hline NREL, USA & Ablative & $35 \mathrm{~kg} / \mathrm{h}$ & [92] \\
\hline PYTEC, Germany & Ablative & $15 \mathrm{~kg} / \mathrm{h}$ & {$[154]$} \\
\hline University of Hamburg, Germany & Ablative & $20 \mathrm{~kg} / \mathrm{h}$ & {$[154]$} \\
\hline Shandong University of Technology, China & Ceramic ball drop flow & $110 \mathrm{~kg} / \mathrm{h}$ & [92] \\
\hline $\begin{array}{c}\text { BEST-Bioenergy and Sustainable Technologies } \mathrm{GmbH} \text {, } \\
\text { Austria }\end{array}$ & Fixed bed & $100-400 \mathrm{~g}$ & {$[158]$} \\
\hline Lisbon Tech, Portugal & Fixed bed & $30 \mathrm{~g}$ & [159] \\
\hline University of Science \& Technology of China & Fixed bed & $500 \mathrm{~g}$ & [92] \\
\hline Aston University, Birmingham, UK & Fluidized bed & $5 \mathrm{~kg} / \mathrm{h}$ & [92] \\
\hline Biomass Engineering Ltd., UK & Fluidized bed & $200 \mathrm{~kg} / \mathrm{h}$ & [92] \\
\hline Cirad, France & Fluidized bed & $2 \mathrm{~kg} / \mathrm{h}$ & [92] \\
\hline Curtin University, Australia & Fluidized bed & $2 \mathrm{~kg} / \mathrm{h}$ & [92] \\
\hline Energy Research Centre of the Netherlands & Fluidized bed & $1 \mathrm{~kg} / \mathrm{h}$ & [92] \\
\hline Guangzou Institute, China & Fluidized bed & $10 \mathrm{~kg} / \mathrm{h}$ & [92] \\
\hline Iowa State University, USA & Fluidized bed & $6 \mathrm{~kg} / \mathrm{h}$ & [92] \\
\hline Karlsruhe Institute of Technology, Germany & Fluidized bed & $100 \mathrm{~g} / \mathrm{h}$ & a \\
\hline Monash University, Australia & Fluidized bed & $1 \mathrm{~kg} / \mathrm{h}$ & [92] \\
\hline $\begin{array}{l}\text { Netherlands Organisation for Applied Scientific Research } \\
\text { (TNO) }\end{array}$ & Fluidized bed & $10 \mathrm{~kg} / \mathrm{h}$ & {$[92]$} \\
\hline NREL, USA & Fluidized bed & $10 \mathrm{~kg} / \mathrm{h}$ & [92] \\
\hline PNNL, USA & Fluidized bed & $1 \mathrm{~kg} / \mathrm{h}$ & {$[92]$} \\
\hline RTI, Canada & Fluidized bed & $20 \mathrm{~kg} / \mathrm{h}$ & {$[92]$} \\
\hline Shanghai JiaoTong University, China & Fluidized bed & $1 \mathrm{~kg} / \mathrm{h}$ & [92] \\
\hline Shenyang University, China & Fluidized bed & $1 \mathrm{~kg} / \mathrm{h}$ & [92] \\
\hline South East University, China & Fluidized bed & $1 \mathrm{~kg} / \mathrm{h}$ & [92] \\
\hline Texas A\&M University, USA & Fluidized bed & $42 \mathrm{~kg} / \mathrm{h}$ & [92] \\
\hline Universidade de Campinas, Brazil & Fluidized bed & $100 \mathrm{~kg} / \mathrm{h}$ & [92] \\
\hline University of Adelaide, Australia & Fluidized bed & $1 \mathrm{~kg} / \mathrm{h}$ & [92] \\
\hline University of Ghent, Belgium & Fluidized bed & $0.3 \mathrm{~kg} / \mathrm{h}$ & [92] \\
\hline University of Hamburg, Germany & Fluidized bed & $\begin{array}{l}60-3000 \mathrm{~g} / \mathrm{h} \\
30 \mathrm{~kg} / \mathrm{h}\end{array}$ & {$[160]$} \\
\hline University of Maine, USA & Fluidized bed & $100 \mathrm{~g} / \mathrm{h}$ & [92] \\
\hline University of Melbourne, Australia & Fluidized bed & $100 \mathrm{~g} / \mathrm{h}$ & [92] \\
\hline University of Naples, Italy & Fluidized bed & $1 \mathrm{~kg} / \mathrm{h}$ & [92] \\
\hline University of Twente, Netherlands & Fluidized bed & $1 \mathrm{~kg} / \mathrm{h}$ & [92] \\
\hline USDA, ARS, ERRC, USA & Fluidized bed & $1 \mathrm{~kg} / \mathrm{h}$ & [92] \\
\hline Virginia Tech, USA & Fluidized bed & $100 \mathrm{~g} / \mathrm{h}$ & [92] \\
\hline vTI, Germany & Fluidized bed & $6 \mathrm{~kg} / \mathrm{h}$ & [92] \\
\hline VTT, Finland & Fluidized bed & $1 \mathrm{~kg} / \mathrm{h}$ & [92] \\
\hline Zhejiang University, China & Fluidized bed & $3 \mathrm{~kg} / \mathrm{h}$ & [92] \\
\hline Zhengzhou University, China & Fluidized bed & $2 \mathrm{~kg} / \mathrm{h}$ & [92] \\
\hline CPERI, Greece & Circulating fluid bed & $1 \mathrm{~kg} / \mathrm{h}$ & [92] \\
\hline Anhui U. of Science \& Technology, China & Sprouted fluid bed & $5 \mathrm{~kg} / \mathrm{h}$ & [92] \\
\hline Ikerlan, Spain & Sprouted fluid bed & $10 \mathrm{~kg} / \mathrm{h}$ & [92] \\
\hline European Biomass Research Institute, Aston University, UK & Stationary fluidized bed & $7 \mathrm{~kg} / \mathrm{h}$ & [151] \\
\hline Georgia Tech, USA & Entrained flow & $56.7 \mathrm{~kg} / \mathrm{h}$ & [161] \\
\hline VTT, Finland & Entrained flow & $20 \mathrm{~kg} / \mathrm{h}$ & {$[151,155]$} \\
\hline Auburn U. USA & Screw & $1 \mathrm{~kg} / \mathrm{h}$ & [92] \\
\hline Michigan State University, USA & Screw & $500 \mathrm{~g} / \mathrm{h}$ & [92] \\
\hline Mississippi State University, USA & Screw & $2 \mathrm{~kg} / \mathrm{h}$ & [92] \\
\hline Texas A\&M University, USA & Screw & $30 \mathrm{~kg} / \mathrm{h}$ & [92] \\
\hline European Biomass Research Institute, Aston University, UK & Twin-screw & $\begin{array}{l}20 \mathrm{~kg} / \mathrm{h} ; \\
100 \mathrm{~kg} / \mathrm{h}\end{array}$ & {$[151]$} \\
\hline Karlsruhe Institute of Technology, Germany & Twin-screw & $10 \mathrm{~kg} / \mathrm{h}$ & [162] \\
\hline TNO, Netherlands & Vortex & $30 \mathrm{~kg} / \mathrm{h}$ & [92] \\
\hline Federal University of Sergipe & Rotary kiln & $0.3 \mathrm{~kg} / \mathrm{h}$ & [163] \\
\hline
\end{tabular}


Table 6. List of pyrolysis plant industrial-pilot, commercial-scale, or expertise providers.

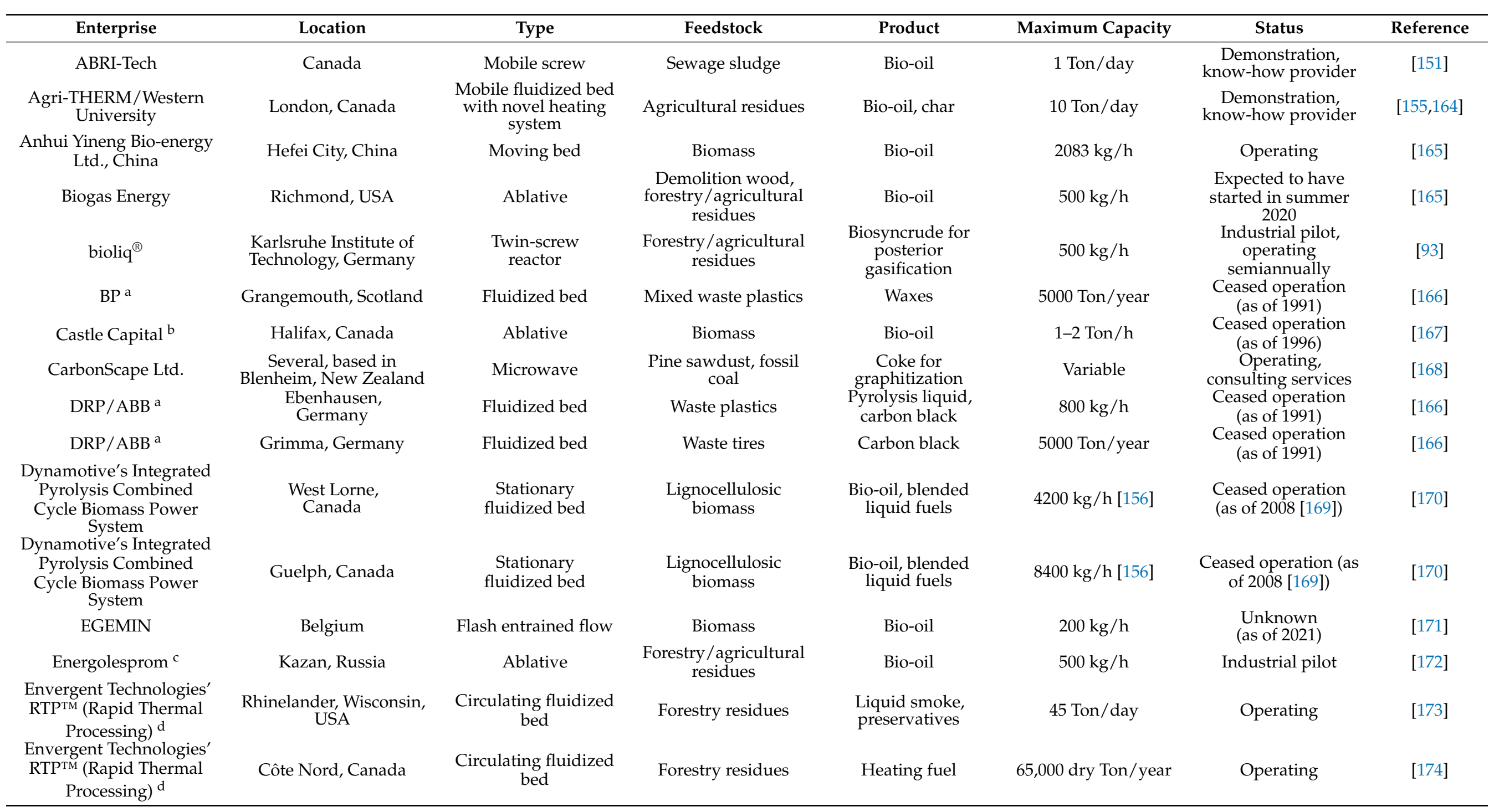


Table 6. Cont.

\begin{tabular}{|c|c|c|c|c|c|c|c|}
\hline Enterprise & Location & Type & Feedstock & Product & Maximum Capacity & Status & Reference \\
\hline $\begin{array}{c}\text { Envergent Technologies' } \\
\text { RTPTM (Rapid Thermal }^{\text {Thessing) }} \\
\text { Proces }\end{array}$ & Aracruz, ES, Brazil & $\begin{array}{l}\text { Circulating fluidized } \\
\text { bed }\end{array}$ & $\begin{array}{l}\text { Eucalyptus residues } \\
\text { from pulp } \\
\text { production }\end{array}$ & Bio-oil & 2.3 MTon/year & Under project & [175] \\
\hline Fortum Orso $^{\circledR e}$ & Joensuu, Finland & $\begin{array}{l}\text { Circulating fluidized } \\
\text { bed }\end{array}$ & Forestry residues & $\begin{array}{l}\text { Bio-oil for district } \\
\text { heating }\end{array}$ & 7 Ton/day & Operating & {$[151,176]$} \\
\hline Interchem ${ }^{c}$ & Kansas, USA & Ablative & Biomass & Bio-oil & $1360 \mathrm{~kg} / \mathrm{h}$ & $\begin{array}{l}\text { Ceased operation } \\
\quad \text { (early 1900s) }\end{array}$ & [167] \\
\hline Lurgi LR & $\begin{array}{l}\text { Ingolstadt, } \\
\text { Germany }\end{array}$ & Twin-screw & Biomass, plastic & $\begin{array}{l}\text { Light and heavy } \\
\text { bio-oil for catalytic } \\
\text { refining }\end{array}$ & $500 \mathrm{~kg} / \mathrm{h}$ [92] & $\begin{array}{c}\text { Unknown } \\
\text { (as of 2021) }\end{array}$ & {$[92,177]$} \\
\hline MRIGlobal $^{\text {b }}$ & $\begin{array}{c}\text { Lutherville-Timonium, } \\
\text { USA }\end{array}$ & Vortex & Biomass & Bio-oil, coke & $3 \mathrm{~cm} / \mathrm{s}$ & Patent & {$[178,179]$} \\
\hline Pyrovac/Corigin & Jonquière, Canada & $\begin{array}{l}\text { Vacuum pyrolysis } \\
\text { using horizontal } \\
\text { conveyers (molten salt } \\
\text { system) }\end{array}$ & Biomass & Bio-oil & $3000 \mathrm{~kg} / \mathrm{h}$ dry & $\begin{array}{l}\text { Demonstration, } \\
\text { know-how provider }\end{array}$ & [180] \\
\hline PyTEC & $\begin{array}{l}\text { Cuxhafen, } \\
\text { Germany }\end{array}$ & Ablative & Biomass & Bio-oil & $250 \mathrm{~kg} / \mathrm{h}[92,156]$ & $\begin{array}{l}\text { Unknown } \\
\text { (as of 2021) }\end{array}$ & [181] \\
\hline $\begin{array}{l}\text { Renewable Oil } \\
\text { International }^{\circledR}\end{array}$ & Florence, USA & Augur & Chicken litter & Bio-oil, char & 5 Ton/day & $\begin{array}{l}\text { Unknown } \\
\text { (as of 2006) }\end{array}$ & [182] \\
\hline $\begin{array}{l}\text { Thermo-Catalytic } \\
\text { Reformer (TCR) }\end{array}$ & $\begin{array}{c}\text { Fraunhofer } \\
\text { UMSICHT, } \\
\text { Sulzbach-Rosenberg, } \\
\text { Germany }\end{array}$ & Catalytic screw & $\begin{array}{l}\text { Sewage sludge, } \\
\text { organic waste }\end{array}$ & $\begin{array}{l}\text { Drop-in fuel, fuel oil } \\
\text { additive, gasoline }\end{array}$ & $300 \mathrm{~kg} / \mathrm{h}$ & Industrial pilot & [183] \\
\hline Toshiba & Sapporo, Japan & Rotating kiln & Mixed plastic waste & $\begin{array}{l}\text { Bio-oil, gas, } \mathrm{HCl} \\
\text { from PVC }\end{array}$ & 14 kTon/year & Operating & [184] \\
\hline Twence/Empyro BV f & $\begin{array}{l}\text { Hengelo, } \\
\text { Netherlands }\end{array}$ & Rotating cone & Forestry residues & Bio-oil & $\begin{array}{l}20 \mathrm{M} \text { liters } \\
\text { bio-oil/year }\end{array}$ & Operating & [185] \\
\hline Twence/Empyro BV f & $\begin{array}{l}\text { Genting, } \\
\text { Malaysia }\end{array}$ & Rotating cone & Palm tree residues & Bio-oil & 6 wet Ton $/ \mathrm{h}$ & Dormant & [186] \\
\hline University of Hamburg & $\begin{array}{l}\text { Hamburg, } \\
\text { Germany }\end{array}$ & Ablative & Biomass & Bio-oil & $250 \mathrm{~kg} / \mathrm{h}$ & Research pilot & [154] \\
\hline $\begin{array}{l}\text { University of Science \& } \\
\text { Technology of China }\end{array}$ & Hefei City, China & Fluidized bed & Biomass & Bio-oil & $650 \mathrm{~kg} / \mathrm{h}$ & Research pilot & [92] \\
\hline Virginia Tech, USA & Blacksburg, USA & Fluidized bed & Poultry litter & Bio-oil, coke & $250 \mathrm{~kg} / \mathrm{h}[156]$ & $\begin{array}{c}\text { Mobile } \\
\text { demonstration pilot }\end{array}$ & [187] \\
\hline $\begin{array}{c}\text { Woodgas Pyrolytics }{ }^{\circledR} \\
\text { Rotatable Covered Cavity } \\
\text { Kiln }\end{array}$ & Normal, USA & Rotating kiln & $\begin{array}{l}\text { Forestry/agricultural } \\
\text { residues }\end{array}$ & Coke, heat & $250 \mathrm{~kg} /$ day & $\begin{array}{l}\text { Demonstration, } \\
\text { know-how provider }\end{array}$ & [148] \\
\hline
\end{tabular}

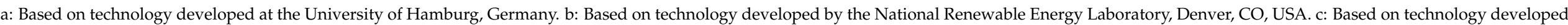

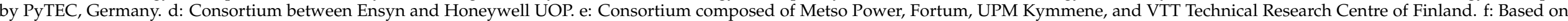
technology developed by the Biomass Technology Group (BTG), based out of Enschede, Netherlands. 


\section{The Pyrolysis Liquid, i.e., the Bio-Oil}

Bio-oil is the name given to any condensed product of biomass pyrolysis. As previously stated, fast pyrolysis maximizes the formation of bio-oil (FPBO) in comparison to similar technologies (Figure 4). FPBO characteristically presents a dark brown color and high viscosity. Its significant environmental advantages in comparison with petroleumderived liquid fuels lay in the fact that its combustion produces nearly half of the $\mathrm{NO}_{\mathrm{x}}$ generated by diesel and meager amounts of $\mathrm{SO}_{\mathrm{x}}$, as well as the fact that it is considered almost $\mathrm{CO}_{2}$ neutral [9]. In terms of chemical composition, $\mathrm{FPBO}$ is a mixture of a variety of organic compounds, of which most are oxygenated, including carboxylic acids, ketones, aldehydes, alcohols, furans, sugars, phenolics, guaiacols, and partially depolymerized lignin (often referred to as pyrolytic lignin); as well as water, ash minerals, and occasionally pyrolysis coke $[90,109,188]$. The distribution of the main compounds observed in an FPBO is depicted in Figure 10.

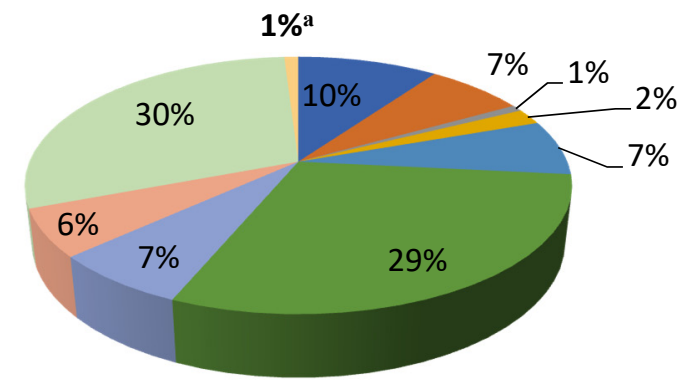

carboxylic acid
aurfural
aldehydes
sugar derivatives
alcohols

Figure 10. Distribution of some of the main constituents of the FPBO. Adapted with permission from Schmitt et al. [137] (2020). Copyright 2020 Copyright Elsevier.

Different biomasses often lead to different chemical compositions of the produced FPBO. FPBO derived from wood biomass usually results in single-phase bio-oil due to a negligible nitrogen and ash concentration, and agricultural residues and waste may lead to a multiphasic FPBO due to excessive formation of water $[11,93,103]$. Moreover, different biomass types often lead to different functional group distributions, as agricultural residues often lead to FPBOs with higher concentrations of phenolic compounds and lower concentrations of aliphatic oxygenates, in comparison to wood [97].

Some undesired characteristics are common to all FPBOs, which can be seen in Table 7. An important focus is given to the oxygen composition and the acidity (low $\mathrm{pH}$, high TAN). The former contributes to a low energy density (roughly half of that of petroleum-derived fuels) in comparison to crude oil and petroleum derivates, makes it more reactive during storage, promoting aging phenomena [189], and often makes it polar, thus immiscible with petroleum-based oils, making it difficult to co-process directly in petroleum refineries. The latter can be attributed to a high concentration of organic acids, making it challenging to use in conventional motors and boilers.

Other relevant drawbacks include a high concentration of pyrolytic lignin oligomers (nearly $30 \mathrm{wt} . \%$ ), which tends to repolymerize during storage [109], as well as a high viscosity and complexity of the oil, leading to poor distillability (Table 7) [190,191].

Despite all those drawbacks, Fast Pyrolysis Bio-oil (FPBO) has been directly employed as fuel for several appliances, including furnaces, boilers, diesel engines, gas turbines, and Stirling engines [190]. Nowadays, the primary application of FPBO is as boiler fuel for heat 
and power $[97,103,130]$. FPBO can also be thought of as a source of platform chemicals, such as anhydrosugars, liquid smoke, and wood preservatives, among others [130].

However, if the ultimate intention is the replacement of fossil-based sources for liquid fuels, chemicals, and other applications, an additional upgrading step is necessary. The changing of properties over time, i.e., higher viscosity and phase separation during storage [11,192], also motivate the progress in upgrading technologies.

Table 7. Elemental composition and physicochemical properties of wheat straw, wheat straw FPBO, generic wood FPBO, and crude oil. Adapted with permission from Funke et al. [13] (2017), Negahdar et al. [193] (2016), and Wang et al. [194] (2013). Copyright 2013, 2016, 2017 Copyright ACS Publications, Elsevier.

\begin{tabular}{ccccc}
\hline & Wheat Straw [13] & Wheat Straw FPBO [193] & Generic Wood FPBO [194] & Crude Oil [194] \\
\hline Carbon (wt.\%) & 42.8 & 45.9 & $40-50$ & 85 \\
Hydrogen (wt.\%) & 5.4 & 7.69 & $6.0-7.6$ & $11-13$ \\
Oxygen (wt.\%) & 38.9 & 41.3 & $36-52$ & $0.1-1.0$ \\
Sulfur (wt.\%) & $\mathrm{n} / \mathrm{a}$ & $\mathrm{n} / \mathrm{a}$ & $0.00-0.02$ & $1.0-1.8$ \\
Nitrogen (wt.\%) & $\mathrm{n} / \mathrm{a}$ & 2.19 & $0.00-0.15$ & 0.1 \\
Water (wt.\%) & 5.7 & 28.4 & $17-30$ & $0.02-0.1$ \\
Solid (wt.\%) & $\mathrm{n} / \mathrm{a}$ & $\mathrm{n} / \mathrm{a}$ & $0.03-0.7$ & 1 \\
pH & $\mathrm{n} / \mathrm{a}$ & $\mathrm{n} / \mathrm{a}$ & $13-2.8$ & $\mathrm{n} / \mathrm{a}$ \\
Viscosity at 323 K (cP) & $\mathrm{n} / \mathrm{a}$ & $\mathrm{n} / \mathrm{a}$ & $16-20$ & 180 \\
HHV $(\mathrm{MJ} / \mathrm{Kg})$ & 16.6 & 21.0 & $1.2-1.3$ & 40 \\
Density $\left(\mathrm{kg} / \mathrm{m}^{3}\right.$ ) & $\mathrm{n} / \mathrm{a}$ & $\mathrm{n} / \mathrm{a}$ & $0.9-1.0$ \\
\hline
\end{tabular}

n/a: Not available.

\subsection{Bio-Oil Upgrading}

To increase the range of FPBO applications, an effort must be put into increasing storage stability, while simultaneously reducing corrosiveness, oxygen, and water content. Thus far, different upgrading techniques have been proposed for use in FPBOs, including filtration, supercritical esterification, addition of solvents, emulsification, extraction, distillation, non-catalytic thermal treatment at high pressures, and catalytic cracking $[90,109,192,195]$. Depending on the intended properties/applications of the final product(s), one or more upgrading techniques may be combined.

Filtration can target inorganic compounds suspended in FPBO. This can be achieved by using a hot gas filtration system (HGF) that can be installed immediately downstream of the reactor in a fast pyrolysis unit, or just before the condensation of the vapors. Elliott et al. [196] applied this technique and showed a substantial reduction in ash content in filtered FPBO (namely K, Ca), as well as higher storage stability [197].

Supercritical esterification is intended to reduce FPBO viscosity and increase its energetic density [90,109]. Water is the most commonly used supercritical medium [90], but Zhan et al. [198] employed supercritical ethanol and methanol while employing acid catalysts for the complete esterification of organic acids. Xu et al. [199] employed supercritical 1-butanol and $\mathrm{Ru} / \mathrm{C}$ catalyst to hydrogenate $\mathrm{FPBO}$, leading to a less oxygenated product of increased energetic density and minimized coke formation. Tang et al. [200] performed hydrogenation of FPBO combined with applying supercritical ethanol as a medium, reporting the virtually complete conversion of aldehydes and ketones, and organic acids to a lesser degree.

Solvent addition can assist in bettering the homogeneity, viscosity, and stability of FBPO while being undemanding and effective, leading to better miscibility with petroleumbased products, a reduced acidity, and a higher energetic density [11,90,109,201]. Alcohols, such as methanol, isopropanol, and ethanol, are the most commonly used solvents, as esterification during storage stabilizes labile compounds (carboxylic acids, aldehydes, and ketones) $[11,201,202]$. While the acids present in the FPBO may catalyze this phenomenon [203], the incorporation of solid acid catalysts can accelerate the process [90].

Instead of solvents, a concurrent process employs mineral fuels and surfactants to emulsify FPBO, aiming at the use of the blend in boilers and combustion engines $[11,90]$. 
While Oasmaa et al. [201] reported successful emulsions containing 5-30\% FPBO, Xiu et al. [90] stated the need to improve the corrosive properties, energetic value, and cetane number of the emulsions.

Non-catalytic thermal treatment requires temperatures higher than $250{ }^{\circ} \mathrm{C}$ and pressure above the partial pressure of water, during which condensation reactions mainly take place, leading to polymerization and phase separation [192,204]. Significant amounts of oxygen and water are removed from the organic-rich product, while the energetic content of this phase is increased in comparison to the feed [192], but a higher viscosity limits its downstream processability [205].

Catalytic cracking demands temperatures of 300 to $600{ }^{\circ} \mathrm{C}$, and employs acid catalysts like silica-alumina, alumina, or zeolites [206]. The target of this process is the deoxygenation of light organics [90], while a considerable amount of char is formed [192,195,207,208].

\subsection{Bio-Oil Catalytic Hydrotreatment}

FPBO may undergo a hydrotreatment (HDT) process analogous to conventional catalytic HDT that takes part in petroleum refineries for desulfurization and denitrogenation [208]. In the case of PFBO, the ultimate objective is its deoxygenation to comply with desired fuel specifications, stabilize reactive compounds, and depolymerize remaining oligomers. The HDT performance may be affected by the concentration of sulfur $(0.3 \mathrm{wt} . \%$ to $0.02 \mathrm{wt} \%$ ) and nitrogen (1.2 to $0.1 \mathrm{wt}$ \% $)$ in the FPBO, although these elements are not the target of the treatment $[189,208-210]$.

Due to the notable differences in the composition between crude petroleum cuts and FPBO (Table 7), different ranges of operating conditions, as well as catalysts, must be applied during HDT of these feedstocks (Table 8) [189]. HDT of bio-oils is a less mature technology when compared to its applicant to petroleum cuts, thus leading to a higher range of temperatures $\left(175-450{ }^{\circ} \mathrm{C}\right)$ and $\mathrm{H}_{2}$ pressures (80-230 bar); the reaction duration may vary (1-6 h) [208,211].

Table 8. Hydrotreatment conditions employed to upgrade crude oil fractions and FPBO. Data obtained from Venderbosch et al. [192], Talmadge et al. [212], and Dabros et al. [189].

\begin{tabular}{ccc}
\hline & Temperature $\left({ }^{\circ} \mathbf{C}\right)$ & $\mathbf{H}_{\mathbf{2}}$ Pressure (Bar) \\
\hline Naphta & $260-350$ & $15-35$ \\
Light oil & $290-400$ & $17-35$ \\
Heavy oil & $350-425$ & $70-140$ \\
Residuum hydrocracking & $400-425$ & $140-200$ \\
Fast pyrolysis bio-oil & $175-450$ & $80-230$ \\
\hline
\end{tabular}

HDT of FPBO comprises a series of concurrent reactions, including decarboxylation, decarbonylation, cracking, hydrocracking, hydrogenation, hydrodeoxygenation, demethylation, demethoxylation, and deoxygenation (Figure 11) [189]. During the hydrotreatment, polymerization and dehydration phenomena might take place in competition with hydrotreatment reactions, with sugars being an example of molecules that can undergo polymerization [192].

The severity and number of HDT stages can be adjusted based on the required properties of the upgraded bio-oil and degree of deoxygenation to be achieved. Hydrotreatment processes can be classified as stabilization as well as deep (simply called HDT) and also in two/multi-step HDT (Figure 12). 
HYDROGENATION<smiles>CC=C[CH2+]CCCCC</smiles>

HYDRODEOXYGENATION

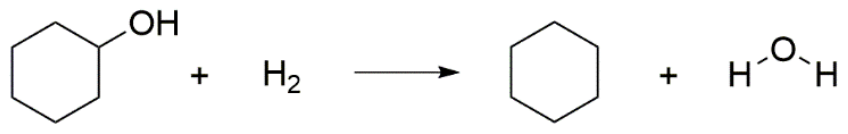<smiles></smiles>

HYDROCRACKING

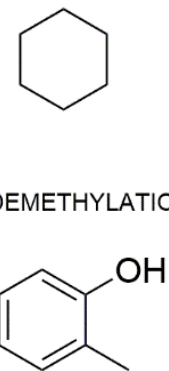<smiles>[C+]CC</smiles><smiles>C1CCCC1</smiles><smiles>CCCCCC</smiles>

DECARBOXYLATION<smiles>CC(=O)O</smiles><smiles>[C+][CH2]</smiles>

CRACKING<smiles>C1CCCCC1</smiles><smiles>C=CCCCC</smiles>

DEMETHOXYLATION<smiles>COc1ccccc1O</smiles><smiles>CO[C@H]1CC[C@@H](Cl)[C@H]1C</smiles>

Figure 11. Representation of the main reaction pathways taking place during the HDT of FPBO. Adapted with permission from Dabros et al. [189] (2018). Copyright, 2018 Copyright Elsevier.

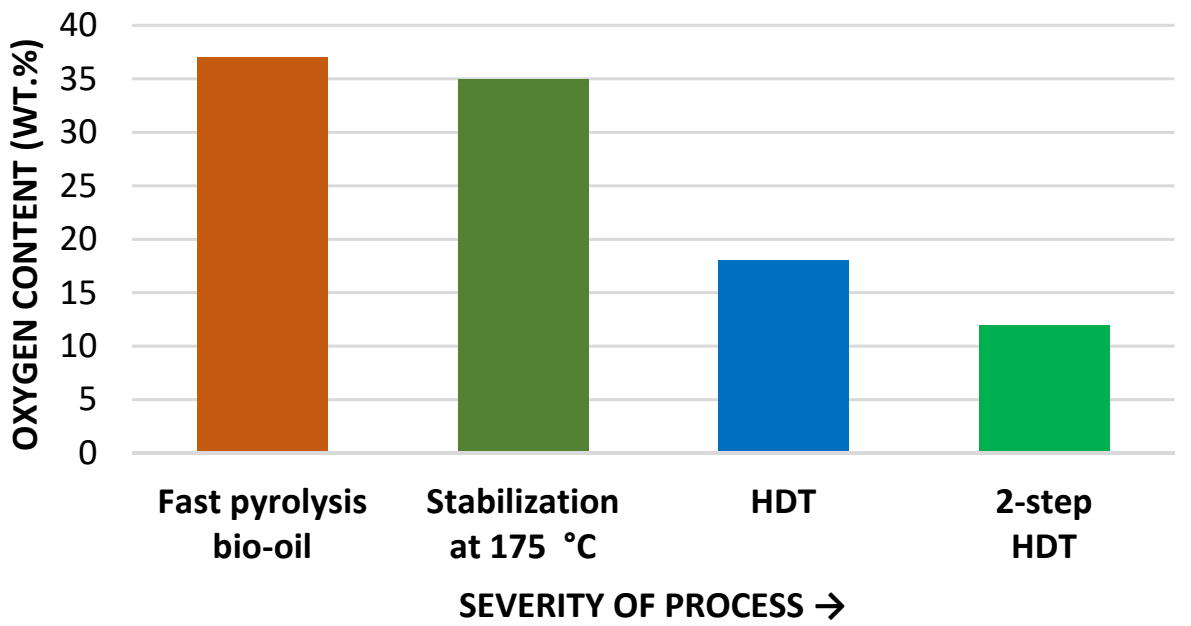

Figure 12. The oxygen content as a function of the hydrotreatment severity. Adapted with permission from Oasmaa et al. [213] (2010). Copyright 2010 Copyright ACS Publications.

Mild hydrotreatment, sometimes also referred to as 'stabilization', is performed at low temperatures, $\left(175-225^{\circ} \mathrm{C}\right)$, mostly targeting labile components, such as ketones, aldehydes, and olefins $[192,213,214]$. Phase separation is not expected during the stabilization, but it might take place depending on the hydrotreatment temperature selected [192]. The upgraded product, when compared to FPBO, shows higher storage stability, reduced plugging of lines, and an ability to be co-processed in conventional refineries together with heavy petroleum cuts $[188,204]$.

Deep hydrotreatment is performed at more severe conditions (up to $450{ }^{\circ} \mathrm{C}$ and 230 bar), aiming to complete hydrodeoxygenation. These severe conditions lead to high $\mathrm{H}_{2}$ consumption and the formation of low-molecular-weight vapors, thus greatly reducing the yield of the liquid product; the costs are considered high [214].

Higher deoxygenation levels are possible through serialized upgrading of FPBO, employing either the same catalyst or different catalysts with differing selectivity [215]. The 
first step aims at the stabilization of the oil and reduction of the tendency of char formation, allowing the second step aiming at hydrodeoxygenation at a higher temperature $[195,216]$. Venderbosch et al. [192] reported higher deoxygenation levels after two-step upgrading, with the O-content dropping from $52.1 \mathrm{wt} . \%$ to $23.9 \mathrm{wt} . \%$ to $14.2 \mathrm{wt} . \%$ (wb.); the authors reported a final upgraded oil with a lower density than water, and an aqueous phase mainly comprised of water. Schmitt et al. [217] reported similar results, with a colorless water-rich (97 wt.\%) aqueous phase (Figure 13).

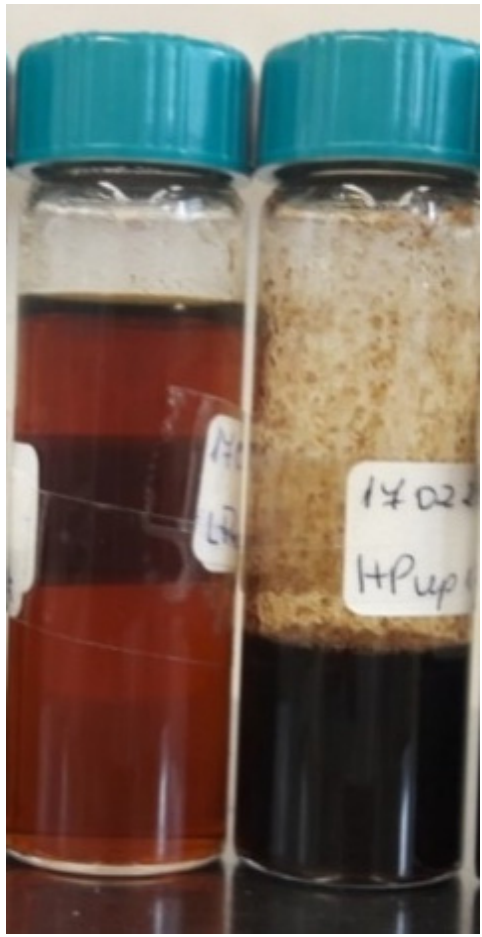

(a)

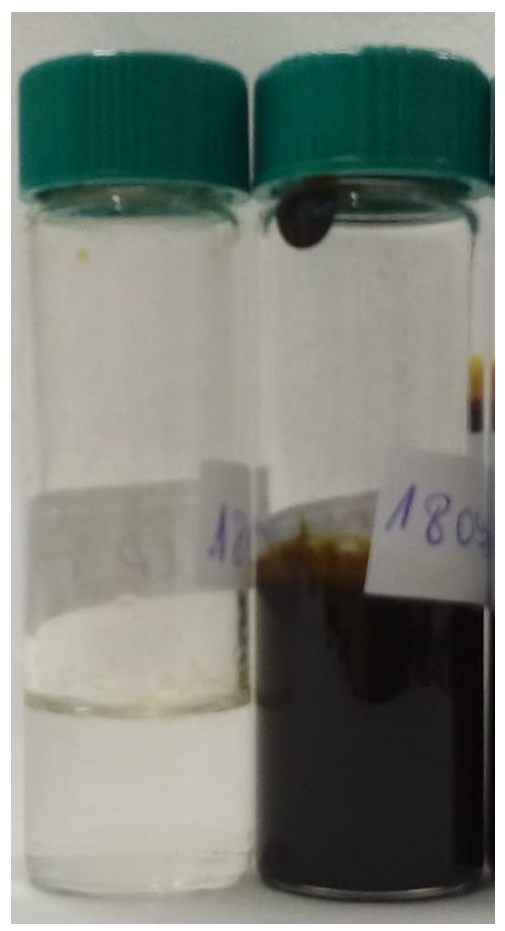

(b)

Figure 13. Upgraded liquid fractions separated after centrifugation. (a) From the left to the right: Upgraded aqueous phase and upgraded oil (b) Upgraded fractions after 2-step upgrading. From the left to the right: Colorless upgraded light phase and upgraded oil.

Van Krevelen plots are often used to depict the efficiency of HDT, which plots O/C and H/C molar ratios, allowing for a visual comparison of the feedstock and products [192]. A reduction of the oxygen concentration is observed by a lowering of the $\mathrm{O} / \mathrm{C}$ ratio, while the $\mathrm{H} / \mathrm{C}$ ratio can be adjusted depending on the specifications (1.5-2.0 for fuels). Another common concern while analyzing the viability of this technology is the loss of liquid product during treatment; a higher degree of deoxygenation correlates to a lower upgraded oil yield due to the production of water and low-molecular-weight gases [208].

If deep deoxygenated levels can be viably achieved, the upgraded product could either substitute fossil fuels or serve as feedstock for the production of commodities. For example, phenolic compounds in FPBO may be used for the production of resins, binders, BTX, phenol, etc. $[4,7,16,65]$ (Figure 14). 


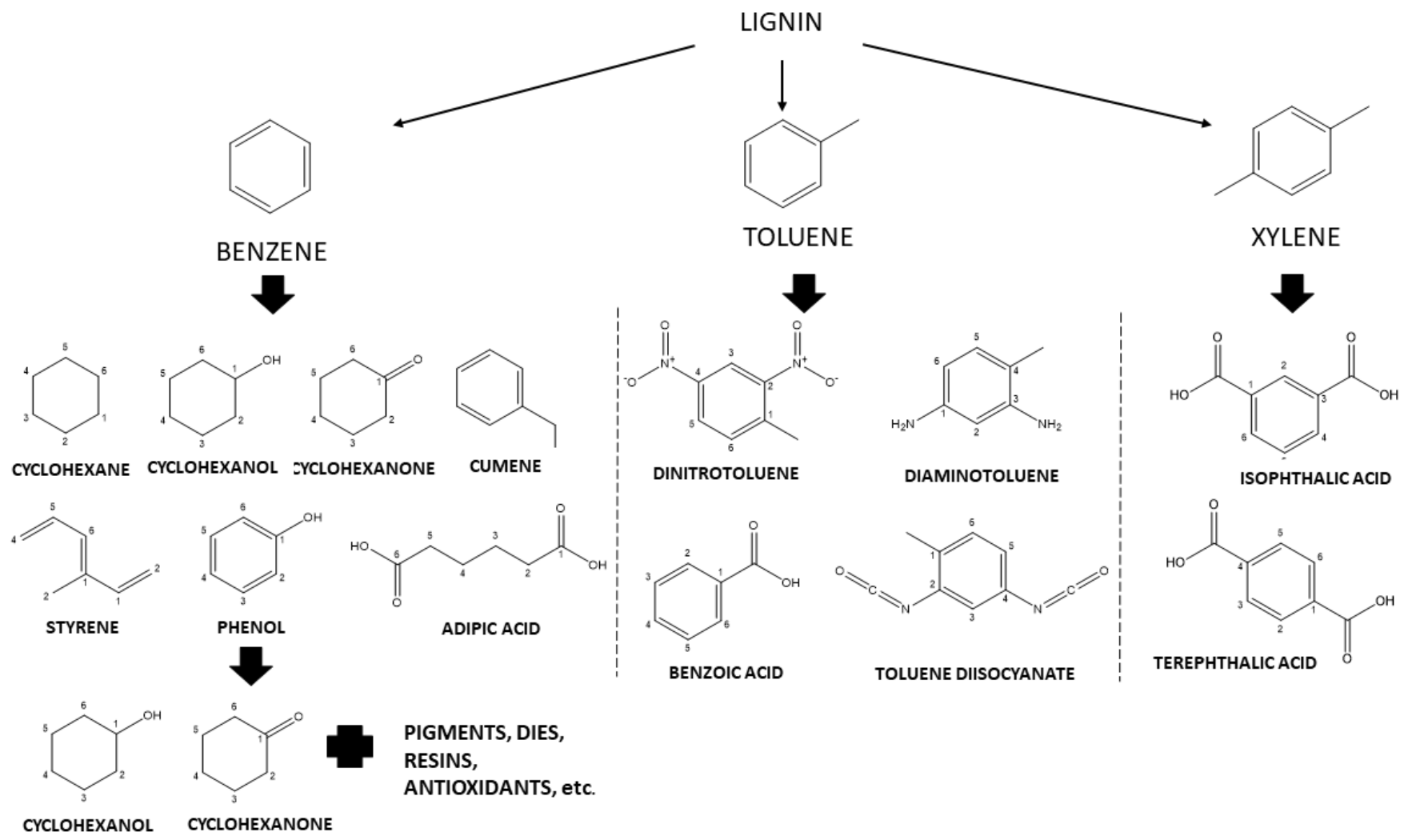

Figure 14. Summary of compounds derived from lignin and the range of chemical products from benzene, toluene, xylene, and phenol. Drawn based on Bozell et al. [218].

Pires et al. [219] presented a variety of compounds derived from FPBO. The authors highlighted that food additives, antioxidants, carbon fibers, olefins, hydrogen, surfactants as well as sugars, and surfactants are some of the products that can be derived from FBPO.

\subsubsection{Parameters Impacting the Bio-Oil Hydrotreatment Reactions}

Reaction parameters, such as the heating rate, type of catalyst used in the HDT reaction, hydrogen pressure, and reaction temperature, will affect the overall hydrotreatment efficiency independently as well as synergistically. Each one of these factors is detailed below.

- Temperature

The hydrotreatment reaction is usually conducted in the range of $175-450{ }^{\circ} \mathrm{C}$. In general, the higher the temperature, the higher the hydrodeoxygenation and the lower the upgraded bio-oil yield. In some cases, i.e., above $350{ }^{\circ} \mathrm{C}$, higher amounts of gaseous products are expected with a minor contribution to the hydrodeoxygenation of the upgraded oil [208]. Overall, the temperature affects the reactivity of the molecules. Oxygenated compounds with low molecular weight react at lower temperatures while molecules with higher complexity are converted at higher temperatures [189]. A simple analysis of this fact can be performed by use of the reactivity scale proposed by Elliot et al. [220], for different FBPO compounds at different temperatures (Figure 15) employing a sulfided NiMo catalyst.

- Hydrogen pressure and consumption

High pressure of $\mathrm{H}_{2}$ is required during the HDT reactions to minimize the formation of coke and increase the solubility of $\mathrm{H}_{2}$ in the FPBO and its availability in the catalytic site $[189,208]$. The $\mathrm{H}_{2}$ consumption already starts at mild temperatures, around $80{ }^{\circ} \mathrm{C}$, and is increased at higher temperatures [204], due to reactions, such as hydrogenation and hydrodeoxygenation. 


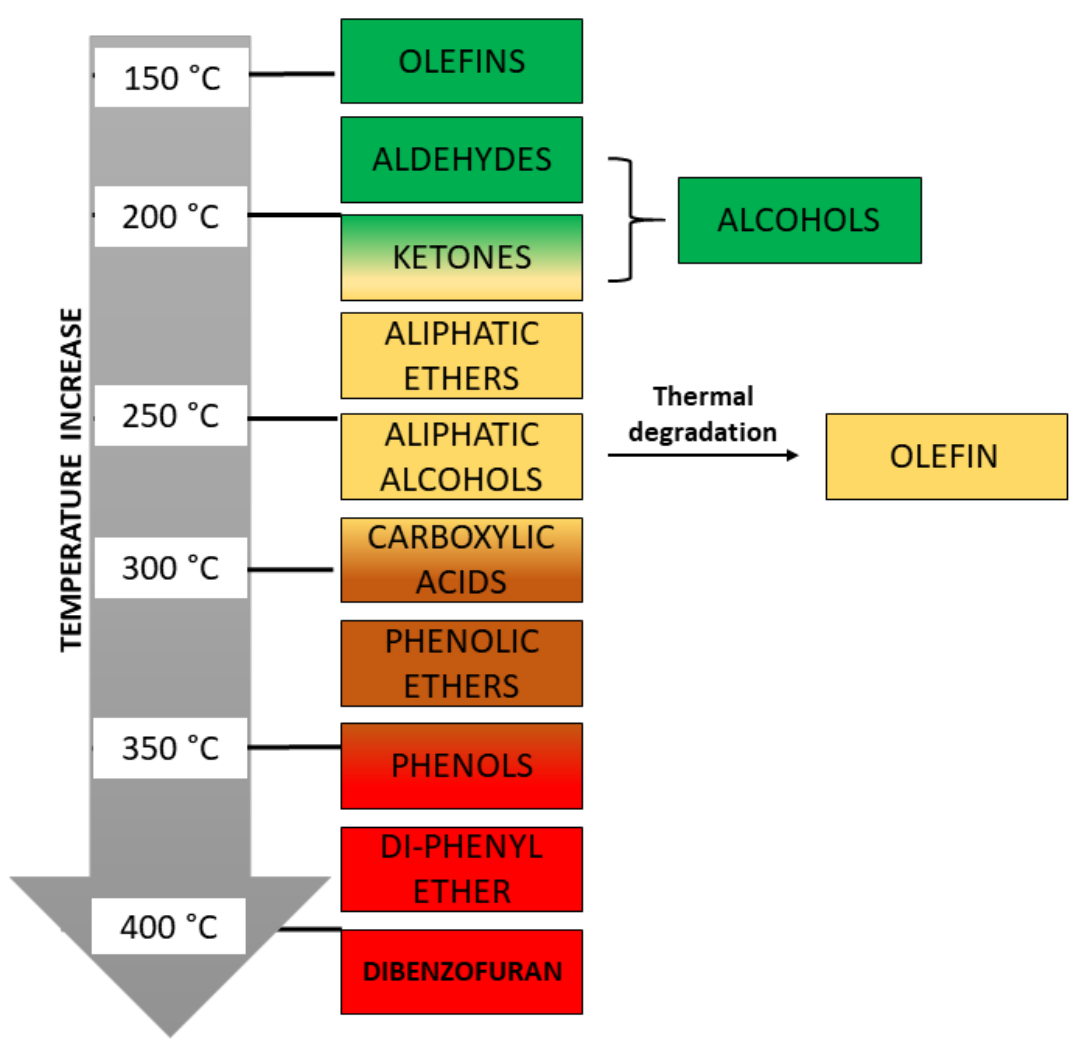

Figure 15. Reactivity scale of FPBO compounds under HDT using sulfided NiMo catalyst at different temperatures. Adapted with permission from Elliott, D. C. [220] (2007). Copyright 2007 Copyright ACS Publications.

When a higher level of deoxygenation is expected, the reaction is conducted at higher severity; therefore, the $\mathrm{H}_{2}$ pressure and its consumption are also higher [212,221]. However, if the reaction is conducted at a significantly high temperature, the adsorption of $\mathrm{H}_{2}$ molecules in the catalyst active site can be negatively impacted, reducing the hydrogenation activity and reaction pathways, such as hydrogenolysis, may take place [221].

- Heating rate

Just a few numbers of publications discuss the influence of the heating rate on the hydrotreatment of FPBO. In one of the very few investigations about this topic, Mercader et al. [204] reported that at a higher heating rate, low $\mathrm{H}_{2}$ consumption is observed, which might be linked to polymerization taking place and being favored at these conditions. The authors also reported that hydrogenation mainly takes place at mild temperatures, but higher heating rated to temperatures above $200{ }^{\circ} \mathrm{C}$ might have an opposite effect, meaning polymerization would be favored and hydrogenation would be unfavored.

- Reaction duration time in batch reactions

Similarly to the heating rate, a small number of studies addressed the impact of the reaction duration over the hydrotreatment. Wildschut et al. [211] studied the impact of the hydrotreatment duration with $\mathrm{Ru} / \mathrm{C}$ at $350{ }^{\circ} \mathrm{C}$ and 20 bar of $\mathrm{H}_{2}$. The duration of the reaction ranged from 1 up to $6 \mathrm{~h}$ of duration. The authors reported that the lowest bio-oil yields and higher gas yields were obtained with longer reactions, and proposed an optimum reaction time of $4 \mathrm{~h}$.

- Catalysts

Together with the parameter previously presented, the catalyst selection is extremely relevant for HDT reactions [109]. The catalyst composition directly affects the conversion of different chemical groups, the reaction selectivity, as well as the cost of the hydrotreatment 
reaction, which overall impacts the HDT performance. Formulation parameters, such as active metal, support, metal concentration, and addition of promoters, play a significant role in the upgraded FPBO composition.

In general, the main catalysts tested in hydrotreatment of FPBO are noble metal catalysts, non-noble transition catalysts, as well as sulfided catalysts.

\subsubsection{Catalysts: Sulfided Catalysts}

The very first HDT of FPBO were conducted with sulfided catalysts, due to their use in petroleum refineries in desulfurization and denitrogenation reactions [195]. Catalysts, such as CoMo and NiMo, have been tested in several studies. Şenol et al. [222] studied the conversion of methyl hexanoate and methyl heptanoate with sulphided $\mathrm{CoMo} / \gamma$ $\mathrm{Al}_{2} \mathrm{O}_{3}$ and $\mathrm{NiMo} / \gamma-\mathrm{Al}_{2} \mathrm{O}_{3}$ in a continuous flow reactor. Both molecules (used as model compound in this study) were converted to hydrocarbons. The highest catalytic activity was observed with $\mathrm{NiMo} / \gamma-\mathrm{Al}_{2} \mathrm{O}_{3}$. The authors observed carbon formation and loss of active sites with both catalysts, which affected the composition of the upgraded products.

Auersvald et al. [223] conducted the hydrotreatment of wheat straw fast pyrolysis biooil with sulphided $\mathrm{NiMo} / \mathrm{Al}_{2} \mathrm{O}_{3}$ in a fixed bed reactor at different pressures (20-80 bars) and temperatures in the range of $240-360{ }^{\circ} \mathrm{C}$. The authors reported that $85 \%$ of the energy content of the biomass was recovered in the upgraded bio-oil and reported reduced acidity and viscosity for most of the conditions evaluated. The HDT at $360^{\circ} \mathrm{C}$ produced an upgraded oil fully miscible with gas oil, which shows potential for co-processing in refineries. Joshi et al. [216] performed HDT reactions of sawdust pyrolysis oil using sulphided $\mathrm{NiMo} / \mathrm{Al}_{2} \mathrm{O}_{3}$. The reactions were conducted in a packed bed microreactor testing different process parameters, such as $\mathrm{H}_{2}$ partial pressure, residence time, and reaction temperature.

The authors reported that during HDT, hydrodeoxygenation and hydrogenation occurred simultaneously. Due to the formation of coke at temperatures above $270{ }^{\circ} \mathrm{C}$, a stabilization step at milder conditions might convert reactive molecules, leading to lower coke formation. French et al. [215] conducted the HDT of oak fast pyrolysis bio-oil with sulphided $\mathrm{NiMo} / \mathrm{Al}_{2} \mathrm{O}_{3}$ and noble metal catalysts in a semi-batch hydrotreatment reactor. Reactions with $\mathrm{NiMo} / \mathrm{Al}_{2} \mathrm{O}_{3}$ showed the lowest consumption of hydrogen and highest conversion of acid compounds in comparison to noble metals. The highest formation of coke was reported with the sulphided catalysts. As distinct selectivity has been observed with both catalysts, the authors suggested a two-step optimized HDT: the first step HDT with noble metal catalysts in order to minimize coke formation while the second step should be conducted with sulphided $\mathrm{NiMo} / \mathrm{Al}_{2} \mathrm{O}_{3}$ targeting hydrodeoxygenation. Gholizadeh et al. [224] studied the HDT of mallee wood bio-oil with sulphided $\mathrm{NiMo} / \mathrm{Al}_{2} \mathrm{O}_{3}$ at $375{ }^{\circ} \mathrm{C}$ and $70-80$ bar. The reactions were conducted in a continuous fixed-bed reactor. The authors reported that high-molecular-weight compounds contributed to the catalyst deactivation while low-molecular-weight molecules seem to have minor contribution.

The hydrodeoxygenation mechanism of 2-ethylphenol over a sulfided $\mathrm{CoMo} / \mathrm{Al}_{2} \mathrm{O}_{3}$ was detailed by He and Wang [225] and Romero et al. [226] (Figure 16).

At first, a $\mathrm{H}_{2} \mathrm{~S}$ molecule is formed by the presence of $\mathrm{H}_{2}$, leading to the formation of a catalyst vacancy site. The $\mathrm{H}_{2}$ is dissociated, leading to the formation of Mo-H and S-H bondings. The molecule of 2-ethylphenol is adsorbed in the catalytic site by the atom of oxygen. A hydrogen proton is donated to the 2-ethylphenol from the S-H bond, resulting in a carbocation; the $\mathrm{C}-\mathrm{O}$ bond is cleaved, and the oxygen-free compound is formed. By the formation of $\mathrm{H}_{2} \mathrm{O}$, the active site is then recovered (Figure 10). Promoters, such as Ni and $\mathrm{Co}$, are commonly applied and used to increase the catalytic activity for hydrotreatment reactions [208,225]. The weakening of S-Mo bonding promoted by the electrons donated from Mo atoms results in the formation of a sulfur vacancy site. Other benefits, such as resistance against catalyst deactivation, have been attributed to promoters (Co and Ni) [189]. 


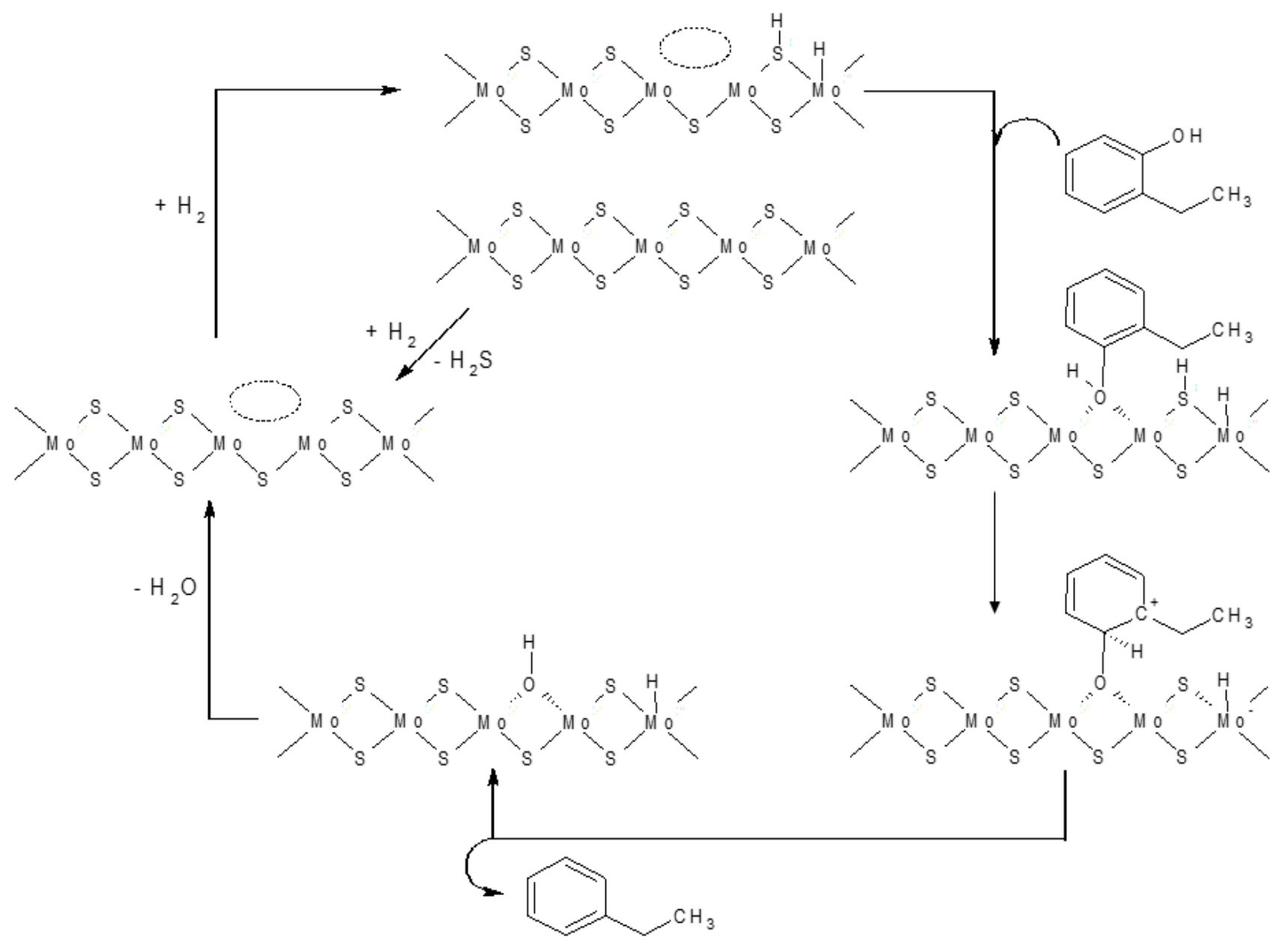

Figure 16. Mechanism of 2-ethylphenol hydrodeoxygenation over a sulfided $\mathrm{CoMo} / \mathrm{Al}_{2} \mathrm{O}_{3}$ catalyst. Adapted with permission from Romero, Y. et al. [226] (2010). Copyright 2010 Copyright Elsevier.

One of the key characteristics of FPBO hydrotreatment employing sulphided catalysts is the need for a continuous sulfur supply to the HDT reactor in order to keep the catalysts' activity $[195,221]$. Together with environmental concerns attributed to sulfur, the increased process cost and poor resistance to water [189] are considered the main limitation attributed to the use of these catalysts in FPBO HDT.

\subsubsection{Catalysts: Noble Metal Catalysts}

Noble metal catalysts are another group of catalysts tested in FPBO hydrotreatment reactions. Ruthenium, palladium, and platinum, and some of the noble metals have already been evaluated for this application [206]. Usually, the high cost of noble metal catalysts combined with the significant high consumption of $\mathrm{H}_{2}$ [195], and high yield of gaseous products [215] are considered the main limitations to establishing a hydrotreatment with these catalysts. Therefore, it motivates the search for cheaper catalysts, most of them non-noble transition elements.

French et al. [215] compared the catalytic activity of $\mathrm{NiMo} / \mathrm{Al}_{2} \mathrm{O}_{3}$ with $\mathrm{Pt} / \mathrm{C}, \mathrm{Pd} / \mathrm{C}$ and $\mathrm{Ru} / \mathrm{C}$. The hydrotreatment reaction took place in a semi-batch reactor with oak fast pyrolysis bio-oil. $\mathrm{Pt} / \mathrm{C}$ showed the highest yield of gaseous products, with this fraction mainly composed by methane. A significant amount of methane formation was also observed with $\mathrm{Ru} / \mathrm{C}$. This catalyst showed low activity for hydrodeoxygenation but hydrogenation activity higher than $\mathrm{NiMo} / \mathrm{Al}_{2} \mathrm{O}_{3}$. Pd/C showed minor hydrodeoxygenation activity and the highest $\mathrm{H}_{2}$ consumption among the catalysts tested. 
Wan et al. [227] evaluated the hydrotreatment of acetic acid in water and n-heptane and the impact of p-cresol over the acetic acid hydrotreatment with $\mathrm{Ru} / \mathrm{Al}_{2} \mathrm{O}_{3}, \mathrm{Ru} / \mathrm{C}$, $\mathrm{Pt} / \mathrm{Al}_{2} \mathrm{O}_{3}, \mathrm{Pt} / \mathrm{C}$, and $\mathrm{Pd} / \mathrm{C}$. Among all catalysts tested, the highest activity was observed with $\mathrm{Ru} / \mathrm{C}$. Acetic acid was mostly converted to ethanol at reactions conducted at $150{ }^{\circ} \mathrm{C}$; at $300{ }^{\circ} \mathrm{C}, \mathrm{CH}_{4}$ and $\mathrm{CO}_{2}$ are the main products. The esterification of ethanol to ethyl acetate is favored by replacing water with $n$-heptane. When $\mathrm{p}$-cresol is included in the model mixture, the reaction pathways previously mentioned are suppressed while formation of methylcyclohexane from hydrodeoxygenation of p-cresol takes place.

Gholizadeh et al. [228] evaluated Pd/C for the HDT of malle wood pyrolysis oil at $375-450{ }^{\circ} \mathrm{C}$ and 70 bar of $\mathrm{H}_{2}$. The long-term HDT was impacted by coke formation (attributed to polymerization), especially at higher temperatures, even with a stabilization step taking place in the upstream stage.

\subsubsection{Niobium-Based Catalysts}

Brazil has circa $85 \%$ of the niobium world reserves and in 2018 , the country was the global main niobium producer. Circa 68,000 tons of contained niobium were mined in Brazil, corresponding to $88 \%$ of the global production, followed by Canada with 7700 tons produced [229].

Niobium can be found in several compounds as oxides, sulfides, halides, and others. Niobium oxides exhibit oxidation states $+5,+4$, and +2 , respectively, with $\mathrm{Nb}_{2} \mathrm{O}_{5}, \mathrm{NbO}_{2}$, and $\mathrm{NbO}$; among them, +5 is the most stable. $\mathrm{NbO}_{2}$ can be obtained by reduction of $\mathrm{Nb}_{2} \mathrm{O}_{5}$ under hydrogen atmosphere at high temperatures $\left(800-1300{ }^{\circ} \mathrm{C}\right)$; however, this transformation is reversible. At even higher temperatures $\left(1300-1600{ }^{\circ} \mathrm{C}\right), \mathrm{NbO}$ is formed and presents a cubic basic unit [230] (Figure 17).

Niobium pentoxide $\left(\mathrm{Nb}_{2} \mathrm{O}_{5}\right)$, the most thermodynamically stable structure, can be amorphous or found in one of the dozens of polymorphic crystalline phases already studied, with different physical properties. The complexity of niobate polymorphs reflects on the several nomenclature systems proposed until now, increasing confusion and contradiction about these crystalline polymorphs [231]. One of the most applicable nomenclature systems was suggested by Schäfer et al. [232]. Based on the German language, Schäfer and colleagues classified the most common phases regarding the temperature they were obtained: TT (Tief-tief; low-low), T (Tief; low), M (Mittel; medium), and H (Hoch; high). Some other polymorphs were also named regarding their particle shape: B (Blatter; leaves), N (Nadeln; needles), and R (Prismen; prisms). Ko and Weissman [233] summarized the most commons crystalline phases obtained from heating the amorphous $\mathrm{Nb}_{2} \mathrm{O}_{5}$. However, besides calcination temperature, the final structure is also affected by impurities, the starting material, and the method of catalyst preparation [234]. Therefore, as previously emphasized, the transition temperature should be seen only as an indicator and not as absolute due to the impact of the many factors mentioned before [233]. The TT phase is formed by calcination at low temperatures $\left(400-500{ }^{\circ} \mathrm{C}\right)$ for a long-term heating and exhibits a pseudo-hexagonal structure. At temperatures between 600 and $800{ }^{\circ} \mathrm{C}$, the $\mathrm{T}$ phase is obtained, which presents orthorhombic unit cells [232]. The $\mathrm{M}$ phase can be obtained for calcination temperatures of around $800{ }^{\circ} \mathrm{C}$ with a tetragonal structure. This phase is normally obtained together with other polymorphs, as the B phase. Calcination at high temperatures $\left(>1000^{\circ} \mathrm{C}\right)$ transforms the amorphous niobium oxide in the $\mathrm{H}$ phase, the most stable thermodynamically phase, presenting a monoclinic structure. 


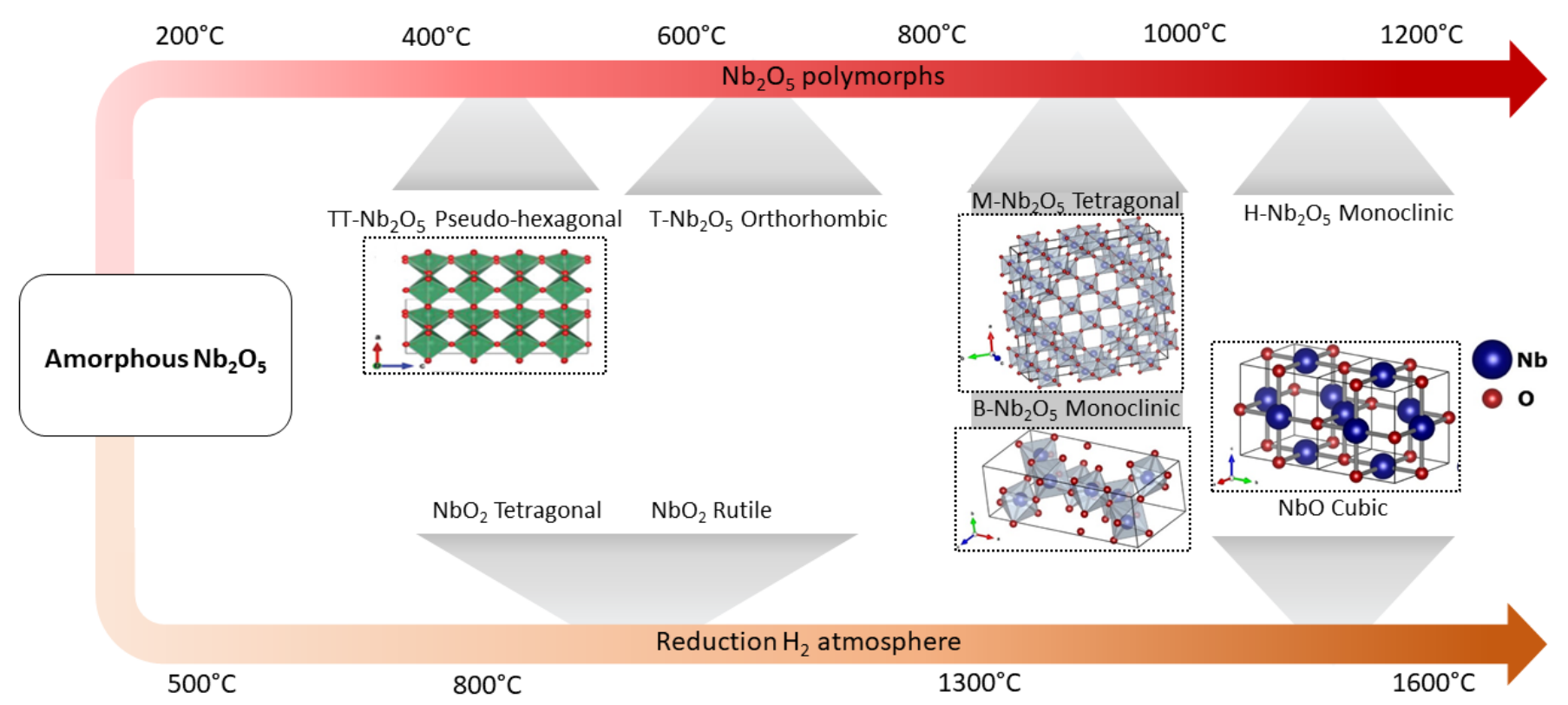

Figure 17. Common niobium oxides and niobates polymorphs. The temperature scale is only indicative, not absolute. The crystalline structures were reproduced from Nico et al. [231] except the TT- $\mathrm{Nb}_{2} \mathrm{O}_{5}$ reproduced from Meng et al. [235]. Adapted with permission from Nico, C. et al. [231] (2016), Meng, J. et al. [235] (2016). Copyright 2016, 2019 Copyright Elsevier, Wiley.

In summary, the niobium pentoxide polymorphs are composed of $\mathrm{NbO}_{6}$ octahedra with different distortion degrees and combined by one of several types of linkage regions, all keeping the $\mathrm{O} / \mathrm{Nb}$ ratio at 2.5. Such variety explains the several polymorphs observed, as highlighted by Schäfer et al. (1966) [232]. Since the distortion degree of octahedral $\mathrm{NbO}_{6}$ rests on the polymorph structure, it results in varied textural and structural abilities. Porosity, surface area, and acidity typically decrease with higher crystallization temperatures. The polymorphism affects the overall catalytic activity of the mentioned crystal phases. The TT phase, for example, is the highest distorted structure and presents the highest number of oxygen vacancies in the structure, which leads to high numbers of Bronsted and Lewis acid sites [236].

Niobium oxides have been previously investigated as catalysts for many reactions, such as dehydration, hydration, etherification, hydrolysis, condensation, dehydrogenation, alkylation, photochemical and electrochemical polymerization, and oxidation [230,237-239]. When combined with different metals and metal oxides, niobium oxides showed strong support and promoter effects and were able to improve the catalysts' activity and selectivity $[230,237]$.

\subsubsection{Niobium Catalysts for Hydrotreatment Reactions}

Niobium-based catalysts have been studied in multifunctional systems for HDT of biomass-derived feed, such as model compounds (phenol, anisole, diphenyl ether, furfural, 4-heptanone, and others) [230,236,240], extracted lignin [241,242], lignin oil (prepared by reductive depolymerization) [243], enzymatic lignin, and pyrolytic bio-oil (gas phase) [244]. The high stability, presence of water-tolerant Lewis acidity, ability of C-O bond cleavage, and the synergism between metal sites, acid sites, and niobium oxide sites are positive characteristics attributed to niobium-containing catalysts. Bifunctional catalysts (noble metal + niobium oxides) are especially promising for hydrotreatment reactions, due to the cleavage ability of $\mathrm{Nb}$ and the hydrogenation ability of noble metals, boosting the catalytic activity on HDT reactions. 


\subsubsection{HDT of Model Compounds with Niobium-Containing Catalysts}

Most of the studies of niobium-containing catalysts for HDT applied model compounds as representatives for lignin or biomass pyrolytic decomposition products, allowing fundamental studies on the catalyst behavior and the reaction mechanism (Table 9). $\mathrm{Nb}_{2} \mathrm{O}_{5}$ has been used as a support in HDT studies of model compounds. Jing et al. [245] converted furfural and 4-heptanone into branched alkanes using $\mathrm{Pd} / \mathrm{Nb}_{2} \mathrm{O}_{5}$ for aldol condensation followed by hydrodeoxygenation. The results showed that the $\mathrm{Nb}_{2} \mathrm{O}_{5}$ promoted aldol condensation (activation of $\mathrm{C}=\mathrm{O}$ bond of carbonyl molecules), $\mathrm{C}-\mathrm{O}$ bond cleavage, and the dehydration reaction. Barrios et al. [240] compared the activity of $\mathrm{Pd} / \mathrm{SiO}_{2}$ and $\mathrm{Pd} / \mathrm{Nb}_{2} \mathrm{O}_{5}$ towards the HDT of phenol in a fixed bed reactor. The activity and selectivity were higher for niobium-supported catalysts in comparison to silica-supported catalysts, due to the interaction between the oxophilic sites on $\mathrm{Nb}$ oxides and the phenolic oxygen. Rezende et al. [246] observed that this interaction decreases the energy required for C-O cleavage. The authors performed phenol gas-phase HDT using several niobium-containing catalyst formulations: $\mathrm{Ni} / \mathrm{Nb}_{2} \mathrm{O}_{5}, \mathrm{Ni} / \mathrm{CeO}_{2}, \mathrm{Ni} / \mathrm{Ce}_{0.30} \mathrm{Nb}_{0.70} \mathrm{O}_{2}$, and $\mathrm{Ni} / \mathrm{Ce}_{0.80} \mathrm{Nb}_{0.20} \mathrm{O}_{2}$. The increasing niobium concentration improved the catalyst activity and the selectivity towards benzene.

Niobium has also been investigated as a promoter for HDT of model compounds in different catalyst formulations. Jin et al. [247] applied different molar ratios of $\mathrm{Nb}-\mathrm{Ni}$ oxide catalyst for anisole HDT. The selectivity to oxygen-free products increased with $\mathrm{Ni}_{0.92} \mathrm{Nb}_{0.08}$ due to the acid sites from amorphous $\mathrm{Nb}_{2} \mathrm{O}_{5}$. However, the addition of niobium to bulk $\mathrm{Ni}$ catalysts reduced the superficial area, which slightly decreased the anisole conversion. Furthermore, a higher niobium concentration reduced the deoxygenation degree due to the formation of inactive $\mathrm{NiNb}_{2} \mathrm{O}_{6}$.

Xue et al. [248] observed lower conversion of 2,5-dimethyltetrahydrofuran (DMTHF) with higher niobium loadings on Pd/SBA-15 catalyst (niobium concentration in the range of 1-14 wt.\% Nb). According to their results, the catalytic performance depends on the state of niobium species, which correlates to the niobium loading. Although increasing the niobium concentration from 1 to $14 \mathrm{wt} . \%$ increased the activity, the turnover frequency based on niobium atoms $\left(\mathrm{TOF}_{\mathrm{T}}\left[\mathrm{h}^{-1}\right]\right.$, defined as the quotient of the total of converted molecules generated per hour and the number of niobium atoms) decreased drastically from 7.7 to 1.4. This compromise is related to the decrease of $\mathrm{Nb}$ species with lower coordination numbers that are able to adsorb oxygen from DMTHF.

Besides the loading impact, Shao et al. [249] evaluated the impact of the catalyst synthesis. The authors synthesized $\mathrm{Pd} / \mathrm{Nb}_{2} \mathrm{O}_{5} / \mathrm{SiO}_{2}$ catalysts for HDT of several model compounds: (4-(2-furyl)-3-buten-2-one; palmitic acid; tristearin and diphenyl ether). Three different $\mathrm{Nb}_{2} \mathrm{O}_{5}$ loadings in silica support $\left(5,10\right.$, and $\left.20 \mathrm{wt} . \% \mathrm{Nb}_{2} \mathrm{O}_{5}\right)$ and two methodologies (wet impregnation and sol-gel) were tested. According to them, the catalyst with $10 \mathrm{wt} . \%$ of $\mathrm{Nb}_{2} \mathrm{O}_{5}$ and $4 \mathrm{wt} . \%$ of Pd prepared by sol-gel presented the highest activity for furan-based HDT and showed an octane yield of $95.5 \%$, in contrast to the low octane yield $(16 \%)$ obtained with $\mathrm{Nb}$-free catalyst. They observed that the sol-gel method resulted in more niobium oxide species exposed on the surface, due to the better dispersion, while the wet impregnation led to larger $\mathrm{Nb}_{2} \mathrm{O}_{5}$ crystallized at the support. The stability of $\mathrm{Pd} / \mathrm{Nb}_{2} \mathrm{O}_{5} / \mathrm{SiO}_{2}$ was tested for palmitic acid and the activity was almost constant in a $150 \mathrm{~h}$ time-on stream test.

Infantes-Molina et al. [250] analyzed the support effect on $\mathrm{PdNb} / \mathrm{SiO}_{2}$ and $\mathrm{PdNb} / \mathrm{PPH}$ (zirconium phosphate heterostructures) for HDT of dibenzofuran. The $\mathrm{PdNb} / \mathrm{SiO}_{2}$ showed the best HDT conversion: between 50 and $80 \%$ of the initial amount of reagent was converted into products free of oxygen, compared to $\mathrm{PdNb} / \mathrm{PPH}$ (between $20-40 \%$ ). $\mathrm{SiO}_{2}$ supported catalysts were also more selective to deoxygenated products (circa $70 \%$ ) compared to PPH-supported catalysts (circa 26\%). Although the silica support presented less surface area $\left(218 \mathrm{~m}^{2} / \mathrm{g}\right)$ than the PPH $\left(534 \mathrm{~m}^{2} / \mathrm{g}\right)$ and consequently less metal dispersion, it had higher stability under impregnation in acid conditions. Regarding the preparation procedure impact, the calcination between $\mathrm{Nb}$ and $\mathrm{Pd}$ incorporation resulted in catalysts 
with higher activity, due to a higher dispersion of the active phase. However, the remaining $\mathrm{Cl}$ from the palladium precursor, $\mathrm{PdCl}_{2}$, was directly correlated to the carbon deposition, related to lower HDT conversion.

Guan et al. [251] studied the multifunctionality of Nb-promoted catalysts. The authors synthesized and applied $\mathrm{Pt} / \mathrm{CN}$ (carbon nanotube) catalysts modified with solid acid nanosheets $\left(\mathrm{HNbWO}_{6}, \mathrm{HNbMoO}_{6}, \mathrm{HTaWO}_{6}\right)$ to the $\mathrm{HDT}$ of diphenylether. According to the authors, the selectivity towards cyclohexane improved from $19.5 \%$ to $96.4 \%$ due to the modification with $\mathrm{HNbWO}_{6}$. The nanosheets were active in the deoxygenation process, while $\mathrm{Pt}$ was involved in the hydrogenation step. The support also had a significant role in the metal dispersion, leading to a conversion of $99.7 \%$ compared to $16 \%$ without the carbon nanotubes.

Zhang et al. [252] discussed the multifunctionality of niobium-modified catalysts supported on carbon composites. They applied $\mathrm{Ru} / \mathrm{Nb}_{2} \mathrm{O}_{5}-\mathrm{MC}$ (micromesoporous carbon) composite on phenol HDT to benzene in biphasic solvents (water and decalin). According to them, the $\mathrm{Nb}$-modified support was responsible for dehydration as well as for the activation of the C-O bond of aromatics. A full conversion of phenol leading to an $80 \%$ selectivity to benzene was achieved due to the synergistic effect between $\mathrm{Ru}$ and the $\mathrm{Nb}_{2} \mathrm{O}_{5}-\mathrm{MC}$ support. The authors assumed that the water phase limited the saturation of benzene molecules.

Jeon et al. [253] performed an aqueous-phase HDT of glycerol with $\mathrm{Ru}-\mathrm{Nb} / \mathrm{Al}_{2} \mathrm{O}_{3}$ catalysts. Synergistic effects between $\mathrm{Ru} / \mathrm{Al}_{2} \mathrm{O}_{3}$ and the promoter $\mathrm{Nb}_{2} \mathrm{O}_{5}$ were responsible for the higher catalytic activity and stability. According to the authors, niobium oxide promoted the stabilization of the boehmite and promoted high dispersion of metallic $\mathrm{Ru}$ nanoparticles, as well as less formation of hard coke precursors.

Table 9. Summary of studies with niobium-based catalysts for HDT of model compounds.

\begin{tabular}{|c|c|c|c|}
\hline Niobium Function & Author & Catalysts & HDT Feed \\
\hline Support & Jing et al. (2019) [245] & $\begin{array}{l}\text { Pd supported on } \mathrm{CaO}, \mathrm{MgO} \text {, } \\
\text { MgAl-HT, } \mathrm{ZrO}_{2}, \mathrm{Al}_{2} \mathrm{O}_{3} \text {, and } \\
\qquad \mathrm{Nb}_{2} \mathrm{O}_{5} .\end{array}$ & Furfural and 4-heptanone \\
\hline Support & Barrios et al. (2018) [240] & $\mathrm{Pd} / \mathrm{SiO}_{2}$ and $\mathrm{Pd} / \mathrm{Nb}_{2} \mathrm{O}_{5}$ & Phenol \\
\hline Support & Rezende et al. (2018) [246] & $\begin{array}{l}\mathrm{Ni} / \mathrm{Nb}_{2} \mathrm{O}_{5}, \mathrm{Ni} / \mathrm{CeO}_{2} \\
\mathrm{Ni} / \mathrm{Ce} 0.30 \mathrm{Nb} 0.70 \mathrm{O}_{2} \\
\mathrm{Ni} / \mathrm{Ce} 0.80 \mathrm{Nb} 0.20 \mathrm{O}_{2}\end{array}$ & Phenol \\
\hline Promoter & Xue et al. (2018) [248] & $\mathrm{Pd}-\mathrm{Nb} / \mathrm{SBA}-15$ & 2,5-dimethyltetrahydrofuran \\
\hline Promoter & Jin et al. (2017) [247] & $\mathrm{Nb}-\mathrm{Ni}$ oxide catalyst & Anisole \\
\hline Promoter & Guan et al. (2019) [251] & $\begin{array}{c}\mathrm{Pt} / \mathrm{CN} \text { with } \mathrm{HNbWO6} \text {, } \\
\mathrm{HNbMoO6} \text {, HTaWO6 } \\
\text { nanosheets }\end{array}$ & Diphenyl ether \\
\hline Promoter & Infantes-Molina et al. (2016) [250] & $\mathrm{Pd}-\mathrm{Nb} / \mathrm{SiO}_{2}$ and $\mathrm{Pd}-\mathrm{Nb} / \mathrm{PPH}$ & Dibenzofurane \\
\hline Promoter & Shao et al. (2015) [249] & $\begin{array}{c}\mathrm{Pd} / \mathrm{Nb}_{2} \mathrm{O}_{5} / \mathrm{SiO}_{2} \text { and } \\
\mathrm{Ni} / \mathrm{Nb}_{2} \mathrm{O}_{5} / \mathrm{SiO}_{2}\end{array}$ & $\begin{array}{l}\text { 4-(2-furyl)-3-buten-2-one; } \\
\text { palmitic acid; tristearin and } \\
\text { diphenyl eter }\end{array}$ \\
\hline Promoter & Zhang et al. (2019) [252] & $\begin{array}{c}\mathrm{Ru} / \mathrm{Nb}_{2} \mathrm{O}_{5} / \text { micromesoporous } \\
\text { carbon }\end{array}$ & Phenol \\
\hline Promoter & Jeon et al. (2018) [253] & $\mathrm{Ru}-\mathrm{Nb} / \mathrm{Al}_{2} \mathrm{O}_{3}$ & Glycerol \\
\hline
\end{tabular}

\subsubsection{HDT of Biomass-Derived Feedstock with $\mathrm{Nb}$-Containing Catalysts}

As highlighted by Leal et al. [254], model reactions lead to experimental limitations on the HDT catalyst design for lignin-containing feedstocks, but very few studies have provided valuable information considering real/realistic biomasses, especially applying $\mathrm{Nb}$-containing catalysts. To minimize the interactions between the sugar-rich and the lignin 
matrix of the biomass, the great majority of the studies are performed with organosolv lignin, i.e., lignin extracted from ground biomass (mostly wood) using methanol and $\mathrm{HCl}$.

Shao et al. [241] and Dong et al. [242] performed HDT of extracted raw birch lignin with $\mathrm{Nb}$-supported catalysts. Shao et al. [241] studied the selectivity and stability in four consecutive tests of $\mathrm{Ru} / \mathrm{Nb}_{2} \mathrm{O}_{5}$ catalyst for HDT of organosolv birch lignin and 4-methylphenol. Even after the fourth consecutive recycling run, the mass yield based on the theoretical monomer for $\mathrm{C}_{7}-\mathrm{C}_{9}$ aromatics was $20.6 \% \mathrm{wt}$., with an aromatic selectivity of $70 \%$. Dong et al. [242] performed HDT of extracted raw birch lignin and 4-methylphenol as a model compound using both $\mathrm{Pd} / \mathrm{Nb}_{2} \mathrm{O}_{5}$ and $\mathrm{Pt} / \mathrm{Nb}_{2} \mathrm{O}_{5}$ catalysts. Comparing the product distribution, $\mathrm{Ru} / \mathrm{Nb}_{2} \mathrm{O}_{5}$ mostly promoted the formation of aromatics, while $\mathrm{Pd} / \mathrm{Nb}_{2} \mathrm{O}_{5}$ and $\mathrm{Pt} / \mathrm{Nb}_{2} \mathrm{O}_{5}$ catalysts predominantly formed cycloalkanes.

Ma et al. [255] compared the performance of $\mathrm{Ru} /$ layered $\mathrm{Nb}_{2} \mathrm{O}_{5}, \mathrm{Ru} / \mathrm{NbPO}$, and $\mathrm{Ru} / \mathrm{Nb}_{2} \mathrm{O}_{5} \cdot \mathrm{H}_{2} \mathrm{O}$ (HY-340) for HDT of both enzymatic lignin and p-cresol as a model compound. The enzymatic lignin is obtained by the enzyme-catalyzed hydrolysis of cellulose from corncobs. According to their study, the layered support had the best molar yield for $\mathrm{C}_{7}-\mathrm{C}_{9}$ hydrocarbons ( $99.1 \%$ ) and a selectivity of $88.1 \%$ to aromatic hydrocarbons.

Xin et al. [244] explored the effect of different synthesis routes on the activity, selectivity, and promoter effect of $\mathrm{Nb}_{2} \mathrm{O}_{5}$ on $\mathrm{Ru} / \mathrm{Nb}_{2} \mathrm{O}_{5}$ for HDT of enzymatic lignin and 4-methylphenol. The different synthesis routes resulted in $\mathrm{Nb}_{2} \mathrm{O}_{5}$ with different properties, such as crystallinity and morphology. Considering the model compound HDT, the layered $\mathrm{Nb}_{2} \mathrm{O}_{5}$ prepared by short hydrothermal synthesis showed excellent selectivity to toluene $(85.9 \%)$ and the highest conversion of 4-methylphenol (25.1\%). Considering the upgrading of enzymatic lignin, a layered catalyst designed to have more unsaturated $\mathrm{NbOx}$ species showed $94.8 \%$ selectivity to aromatic hydrocarbons for HDT in the water phase.

Leal et al. [254] applied water-tolerant Ni-supported TT- $\mathrm{Nb}_{2} \mathrm{O}_{5}$ (pseudohexagonal phase) nanorods of different Ni loadings as catalysts for lignin oil HDT (produced by an upstream process of catalytic biorefining), as well as using diphenyl ether as a model compound. The model reaction yielded $91 \%$ of cyclohexane after five reaction runs using the catalyst with $15 \% \mathrm{Ni}$. Despite the promising results for the model compound, the catalyst showed a progressive loss of activity and selectivity to the dehydration of cyclohexanol species, most likely because of accumulated side-products blocking Lewis acid sites.

$\mathrm{Li}$ et al. [243] applied $\mathrm{RuFe} / \mathrm{Nb}_{2} \mathrm{O}_{5}$ as catalyst for birch lignin oil and 3-(4-hydroxyphenonyl)propanol for integrated dehydrogenative decarbonylation (DHDT) and HDT reactions. This lignin oil was produced through reductive depolymerization with methanol, hydrogen gas, and $\mathrm{Pd} / \mathrm{C}$. Their results pointed that the inclusion of Fe in the catalyst increased the ethylbenzene selectivity and the deoxygenation degree in general.

To the best of our knowledge, only Barrios et al. [240] has applied niobium-based catalysts in the HDT reaction of real pyrolysis bio-oil, but more specifically in the vapor phase. They performed vapor-phase hydrodeoxygenation of pine pyrolysis product and model compounds with three catalysts: $\mathrm{Pd} / \mathrm{SiO}_{2}, \mathrm{Pd} / \mathrm{Nb}_{2} \mathrm{O}_{5}$, and $\mathrm{Pd} / \mathrm{NbOPO}_{4}$. The authors observed a reduction of the oxygenated yields by $59 \%$ and $43 \%$ wt. $\%$ feedstock-basis, respectively, for the catalysts $\mathrm{Pd} / \mathrm{Nb}_{2} \mathrm{O}_{5}$ and $\mathrm{Pd} / \mathrm{NbOPO}_{4}$. In comparison, the $\mathrm{Pd} / \mathrm{SiO}_{2}$ presented a reduction of only $24 \%$ in the oxygenated yields. According to the authors, the extent of deoxygenated products correlates to the presence of niobium in both support and oxophilic sites $\left(\mathrm{Nb}^{4+}, \mathrm{Nb}^{5+}\right)$.

A summary of HDT studies with biomass-derived feedstocks using niobium-containing catalysts is available in Table 10. 
Table 10. List of studies conducted with niobium-based catalysts and real biomass feed.

\begin{tabular}{|c|c|c|c|}
\hline $\begin{array}{l}\text { Niobium } \\
\text { Function }\end{array}$ & Publication & Catalysts & HDT Feed \\
\hline Support & Teles et al. (2018) [256] & $\begin{array}{c}\mathrm{Pd} / \mathrm{SiO}_{2}, \mathrm{Pd} / \mathrm{Nb}_{2} \mathrm{O}_{5} \\
\mathrm{Pd} / \mathrm{NbOPO}_{4}\end{array}$ & $\begin{array}{l}\text { Pine pyrolysis product, phenol, } \\
\text { anisole, m-cresol, guaiacol (vapor } \\
\text { phase HDT). }\end{array}$ \\
\hline Support & Li et al. (2020) [243] & $\mathrm{RuFe} / \mathrm{Nb}_{2} \mathrm{O}_{5}$ & $\begin{array}{c}\text { Birch lignin oil, } \\
\text { 3-(4-hydroxyphenyl)propanol }\end{array}$ \\
\hline Support & Dong et al. (2018) [242] & $\mathrm{Pd} / \mathrm{Nb}_{2} \mathrm{O}_{5}$ and $\mathrm{Pt} / \mathrm{Nb}_{2} \mathrm{O}_{5}$ & $\begin{array}{c}\text { Extracted raw birch lignin, } \\
\text { 4-methylphenol }\end{array}$ \\
\hline Support & Shao et al. (2017) [241] & $\mathrm{Ru} / \mathrm{Nb}_{2} \mathrm{O}_{5}$ & $\begin{array}{l}\text { Extracted birch lignin, } \\
\text { 4-methylphenol }\end{array}$ \\
\hline Support & Xin et al. (2019) [244] & $\begin{array}{c}\mathrm{Ru} / \mathrm{Nb}_{2} \mathrm{O}_{5} \\
\mathrm{Ru} / \text { layered } \mathrm{Nb}_{2} \mathrm{O}_{5}\end{array}$ & 4-methylphenol, enzymatic lignin. \\
\hline Support & Ma et al. (2019) [255] & $\begin{array}{c}\mathrm{Ru} / \mathrm{NbPO}, \mathrm{Ru} / \mathrm{Nb}_{2} \mathrm{O}_{5} \cdot \mathrm{H}_{2} \mathrm{O} \\
(\mathrm{HY}-340)\end{array}$ & Enzymatic lignin, p-cresol \\
\hline Support & Leal et al. (2019) [254] & $\mathrm{Ni} / \mathrm{TT}-\mathrm{Nb}_{2} \mathrm{O}_{5}$ nanorods & $\begin{array}{l}\text { Lignin oil from catalytic upstream } \\
\text { biorefining, diphenyl ether }\end{array}$ \\
\hline
\end{tabular}

\subsubsection{Catalysts: Nickel-Based Catalysts}

Due to their lower cost and higher availability, non-noble transition metals (which include $\mathrm{Ni}$ ) are increasingly used in a variety of catalytic processes, including hydrogenation, and are prime candidates for the development of new catalysts for the HDT of FPBO.

Figure 18 shows the most commonly accepted mechanism of hydrotreatment over reduced transition metal catalysts. This proceeds by the adsorption of oxygenates on either the support (non-noble metal) or the noble metal particle, or even the metal/support interface and subsequent activation, while the adsorption/dissociation of $\mathrm{H}_{2}$ takes place exclusively on the metal surface. The pre-activation lowers the energy barrier enough to greatly promote the rate of hydrogenation/hydrodeoxygenation [208,225,257]. Dabros et al. [189] debate that the interaction between the metal and support may influence the overall catalytic mechanism.

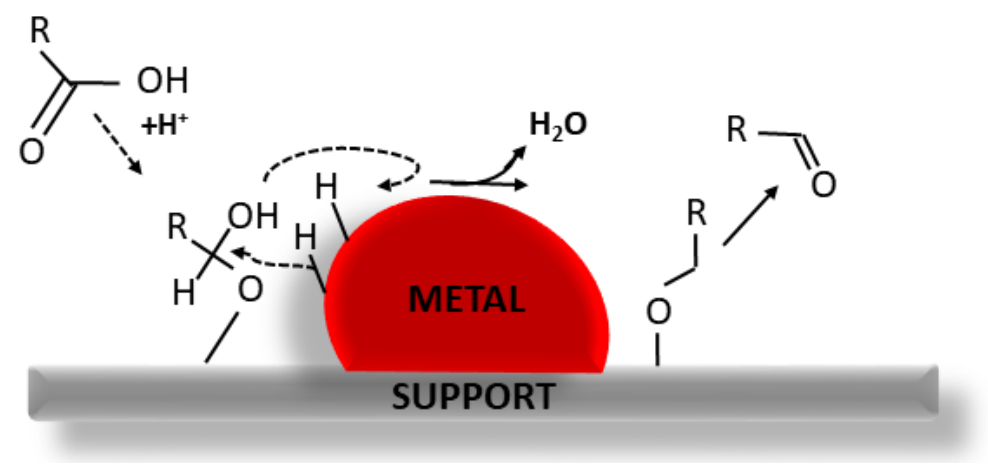

Figure 18. Mechanism of hydrotreatment over reduced transition metal catalysts. Adapted with permission from Mortensen et al. [208] (2011). Copyright 2011 Copyright Elsevier.

Ardiyanti et al. [258] studied eight different nickel-based catalysts ( $\mathrm{NiCu}$ and NiPd supported on $\mathrm{SiO}_{2}, \mathrm{La}_{2} \mathrm{O}_{3}$, kaolin, and $\mathrm{ZrO}_{2}$ ) with different loadings (29-58 wt.\% Ni) for the batch hydrotreatment of pine wood bio-oil. The NiPd catalyst with $58 \mathrm{wt} . \% \mathrm{Ni}$ showed the highest activity and lowest coking, leading to an upgraded product with the lowest oxygen concentration and highest solubility in hydrocarbons. $\mathrm{Bar} \mathrm{ZrO}_{2}$, all the other supports led to lower production of methane in comparison to $\mathrm{Ru} / \mathrm{C}$.

Ardiyanti et al. [259] investigated the performance of NiCu-based catalysts in different supports $\left(\mathrm{ZrO}_{2}, \mathrm{CeO}_{2}-\mathrm{ZrO}_{2}, \mathrm{TiO}_{2}, \mathrm{Al}_{2} \mathrm{O}_{3}\right.$, Sibunite, and rice husk carbon), varying the concentrations of both $\mathrm{Ni}$ and $\mathrm{Cu}$. NiCu/TiO 2 was shown to be the most active catalyst, based on the hydrogen consumption and the highest $\mathrm{H} / \mathrm{C}$ ratio of the upgraded product. 
$\mathrm{NiCu}$ /Sibunite, despite not being the most active catalyst, led to an upgraded oil with the lowest $\mathrm{O}$ content.

Ardiyanti et al. [260] applied a range of $\mathrm{NiCu} / \mathrm{Al}_{2} \mathrm{O}_{3}$ catalysts with different metal loadings (0.32-0.81 wt.\%) for the HDT of anisole and pine wood bio-oil. The catalyst with a metal loading ratio $(\mathrm{Ni} / \mathrm{Cu})$ of 8 led to the best results, namely the highest consumption of $\mathrm{H}_{2}$ and highest $\mathrm{H} / \mathrm{C}$ in the final product.

Mortensen et al. [257,261,262] conducted a series of investigations focused on the use of Ni-based catalysts for the HDT of bio-oil or model compounds. The first concerned the degradation of phenol at $275{ }^{\circ} \mathrm{C}$ and $100 \mathrm{bar}$, and the authors classified the different employed catalysts in the following order: $\mathrm{Ni} / \mathrm{ZrO}_{2}>\mathrm{Ni}-\mathrm{V}_{2} \mathrm{O}_{5} / \mathrm{ZrO}^{2}>\mathrm{Ni}-\mathrm{V}_{2} \mathrm{O}_{5} / \mathrm{SiO}_{2}>$ $\mathrm{Ru} / \mathrm{C}>\mathrm{Ni} / \mathrm{Al}_{2} \mathrm{O}_{3}>\mathrm{Ni} / \mathrm{SiO}_{2} \gg \mathrm{Pd} / \mathrm{C}>\mathrm{Pt} / \mathrm{C}$ [257]. An important conclusion is that oxide support is necessary to promote the heterolytic dissociation of $\mathrm{O}-\mathrm{H}$ in molecules, such as phenol [257].

In another study with similar operating conditions, Mortensen et al. [262] investigated the influence of different-sized $(5-22 \mathrm{~nm})$ nickel particles $\left(\mathrm{Ni} / \mathrm{SiO}_{2}\right)$ to promote the hydrodeoxygenation of phenol and observed higher deoxygenation rates when using smaller nickel particles $(5 \mathrm{~nm})$, attributed to a higher occurrence of step/corner active sites, while hydrogenation was promoted by larger metal particles.

Boscagli et al. [263] compared the catalytic activity during batch HDT of six nickelbased catalysts $\left(\mathrm{Ni} / \mathrm{Al}_{2} \mathrm{O}_{3}, \mathrm{NiCu} / \mathrm{Al}_{2} \mathrm{O}_{3}, \mathrm{Ni} / \mathrm{SiO}_{2}, \mathrm{Ni} / \mathrm{ZrO}_{2}, \mathrm{NiW} / \mathrm{AC}\right.$, and $\mathrm{Ni} / \mathrm{TiO}_{2}$ ) to that of $\mathrm{Ru} / \mathrm{C}$, at $250{ }^{\circ} \mathrm{C}$ and $8 \mathrm{MPa}$. The system under study was a light water-rich phase obtained from the fast pyrolysis of wheat straw, featuring a high concentration of low-molecular-weight compounds, such as carboxylic acids, sugar, aldehydes, and ketones, thus a simplified system compared to a single-phase FPBO. Ni-based catalysts showed slightly higher activity and selectivity to olefins when compared to the reference catalyst. The authors observed that the selectivity is highly impacted by the reaction medium: while the HDT of phenol in aqueous solution resulted mainly in cyclohexanol, its conversion in the light FPBO phase led chiefly to cyclohexanone.

Schmitt et al. [217] performed a similar test to that done by Boscagli et al. [263], focused on two Ni-based catalysts, $\mathrm{Ni}-\mathrm{Cr} / \mathrm{SiO}_{2}(50 \mathrm{wt} . \% \mathrm{Ni})$ and $\mathrm{Cr}_{2} \mathrm{O}_{3}-\mathrm{Ni} / \mathrm{SiO}_{2}(60 \mathrm{wt}$.\% Ni). A higher bio-oil yield, attributed to lower gas formation, was reported for these catalysts in comparison to $\mathrm{Ru} / \mathrm{C}$, as well as an overall higher activity and conversion of ketones, sugars, and carboxylic acids, namely when employing the Ni-Cr catalyst. The authors also reported the results of a 2-step HDT using these catalysts, resulting in a reduction of $65 \mathrm{wt} . \%$ of O-content and $90 \mathrm{wt} . \%$ of water compared to the original liquid feedstock.

Despite the validity of the results presented here, predominant factors, such as the reactor design, active metal loading, operating conditions, and feedstock, limit the direct application of results to further developments, thus demanding continuous research and scale-up application studies.

\subsubsection{Catalysts: Supports}

The choice of the right support material is fundamental for the correct formulation of HDT catalysts, as it is the main factor responsible for the stabilization and dispersion of active metal, as well as the selectivity and activity of the catalysts [195]. Common supports include $\gamma-\mathrm{Al}_{2} \mathrm{O}_{3}, \mathrm{SiO}_{2}, \mathrm{ZrO}_{2}$, activated carbon, and $\mathrm{CeO}_{2}$, without disregarding the possibility of combinations of support materials [109].

Alumina, mainly $\gamma-\mathrm{Al}_{2} \mathrm{O}_{3}$, is a commonly used acid catalyst and support (namely for S-based catalysts $[215,216,223,224]$ ), which shows higher activity than $\mathrm{SiO}_{2}$ and activated carbon but is deactivated in the presence of water (converted to böhmite) and catalyzes the polymerization of phenolics into coke, leading to a fast deactivation [188,212].

Despite presenting a lower activity when compared to $\gamma-\mathrm{Al}_{2} \mathrm{O}_{3}$ [195], $\mathrm{SiO}_{2}$ shows a lower coke formation tendency under similar conditions, therefore being considered a more viable support for HDT of FPBO $[208,226]$. For similar reasons, $\mathrm{ZrO}_{2}$ is also considered a 
promising support, possibly promoting the activation of oxygenated compounds on its surface [226].

Activated carbon is an inexpensive alternative to other acidic supports that features a higher surface area and resistance to water and lower acidity and coke formation in comparison [212,221]. Nonetheless, calcination and other high-temperature regeneration techniques do not apply to activated carbon, thus requiring disposal or future regeneration alternatives [212].

$\mathrm{CeO}_{2}, \mathrm{TiO}_{2}, \mathrm{MgO}$, and niobium oxides, less traditional supports, have been tested for HDT/HDO [109,220], and feature a higher dispersion and activity, as well as a reduced tendency for coke formation when compared to conventional options [226].

To be employed for the upgrading of FPBO, a support is required to be stable in the presence of water, due to a significant fraction present in the feedstock, in addition to the amount formed doing hydrotreatment. Other desirable attributes include a high surface area, which promotes a high dispersion of the active metal particles, and a moderate acidity that does not lead to excessive coking $[189,195]$.

\subsection{Catalysts: Deactivation Mechanisms of Hydrotreatment Catalysts}

Deactivation of a catalyst is observed whenever its activity and/or selectivity is diminished during operation. Phenomena of deactivation include poisoning, sintering, coking, leaching, and catalyst degradation [191,208,264], of which water-promoted degradation, coking, and leaching are prevalent during HTL or FPBO [189,191]. Poisoning due to the presence of $\mathrm{S}, \mathrm{Cl}, \mathrm{Ca}$, and $\mathrm{K}$ may occur due to irreversible adsorption or bonding with the active site or reaction with the active metal sites [221]. Over time, effects, such as sintering of active metal sites, are induced by high temperatures and lead to a loss of surface area [206]. The presence of carboxylic acids in the feedstock may induce the leaching of active metals into the aqueous upgraded phase [206].

Among these, coking is undoubtedly the most relevant mechanism of deactivation during FPBO hydrotreatment. The formation of coke is attributed to polymerization and condensation reactions concurrent with HDT, thus requiring the use of catalysts with moderate acidity [189,195]. Shafaghat et al. [221] reported a tendency of the formation of coke to oxygenated components containing more than one oxygen atom, as well as lignin-derived compounds [221]. This phenomenon can never be avoided but attempts to mitigate it employed high pressures of $\mathrm{H}_{2}$ and moderate temperatures [191,196].

The main challenge, therefore, is the development of a stable catalyst with high selectivity for deoxygenation, and low $\mathrm{H}_{2}$ consumption, while being resistant to poisoning substances, and able to be regenerated [195]. Such a discovery would enable the production of a broad range of commodities in a fast pyrolysis/upgrading-based biorefinery.

\section{Biorefineries}

There are several proposals of biorefinery concepts centered on the pyrolysis of lignocellulosic biomass and the upgrading of its liquid products. Agricultural biomass presents a low bulk density, which corresponds to costly transportation and storage, therefore hindering the competitiveness of any transformation process based on this premise [265-268]. The setting-up of market hubs, based on the availability of feedstock within a certain radius, for storage and trading of biomass can assist primary producers with clearing down stocks and obtaining extra revenue, thus generating market liquidity $[269,270]$. Another approach may be the establishment of bio-based industries, which are versatile in terms of feedstocks, as several biomasses are disregarded due to unfavorable characteristics, such as moisture and ash content [271]. However, it must be kept in mind that farmers and forestry managers often use at least a fraction of this residual biomass alike as a soil fertilizer as part of land management practices (crop rotation, tree nurseries, etc.), thus reducing the possible mass potential [272].

New opportunities, such as the so-called Bioenergy Combined with Carbon Capture, Utilization, and Storage (BECCUS), are certainly of short-term interest for further invest- 
ments. Projections show the need for the removal of up to 16 billion ton of $\mathrm{CO}_{2}$ from the atmosphere per year in 2100 [273]. Consoli [274] compiled a review of the existent and planned BECCS facilities around the world, and reinforced the relevance of this technology to achieve the target atmospheric $\mathrm{CO}_{2}$ levels. In this way, fast pyrolysis could provide liquid bio-oil and solid biochar for long-term storage, e.g., in form of soil applications. In addition, the by-produced $\mathrm{CO}_{2}$ could be separated, and either stored or employed in synthesis processes. Recent studies on the combustion of biomass in an $\mathrm{N}_{2}$-free atmosphere may contribute to the abatement of current carbon capture costs $\left(50-90 € / \mathrm{Ton}^{\mathrm{CO}} \mathrm{O}_{2}\right.$ to $15-25 € /$ Ton $\mathrm{CO}_{2}$ ) [275].

\section{Pyrolysis-Centered Biorefineries}

Pyrolysis could be utilized in different types of biorefinery concepts. To solve the problem of low feedstock energy density and thus high transportation costs, fast pyrolysis could act for pre-treatment of biomass, yielding an energy-dense intermediate for cheaper transportation and easier handling in de-centralized plants supplying a large industrial facility for further conversion to synthetic fuels. Alternatively, the FPBO can be upgraded to different fuel qualities for co-processing in a refinery [276], or for the direct production of fuel components with or without co-production of chemicals, as exemplified by the PyRefinery concept by the Iowa State University [277].

The bioliq ${ }^{\circledR}$ concept [278] is one example of the decentralized densification/central refining concept, by considering the presence of several small-scale fast pyrolysis units installed in proximity with the biomass supply, which produce a mixture of FPBO and biochar dubbed "biosyncrude" that features an energy density around 6 times that of the solid feedstock. This material can be easily stored over long periods and economically transported to large-scale biorefineries, in which it is gasified and converted to liquid hydrocarbons using the methanol-to-olefins process [189].

In this document, we would like to propose a second valorization pathway, which also begins with the fast pyrolysis of agricultural residues. In this co-processing concept, the FPBO is not mixed with the coke, but rather directly transported from the network of small pyrolysis units to the central refinery. Here, it may undergo hydrotreatment to be either fully or partially deoxygenated, or just stabilized, depending on both the feedstock properties and target oil properties. The produced oil may be integrated into a conventional petroleum refinery and make use of its structure for processing, distribution, and $\mathrm{H}_{2}$ supply $[205,212]$. While the properties of the upgraded oil may vary significantly, miscibility with petroleum-derived products may have been acquired, allowing for co-feeding into different refinery streams (Figure 19), and not requiring a very low $\mathrm{O} / \mathrm{C}$ ratio $[260,279]$. However, two-step HDT may be desired for deep HDO, producing final products that can be blended directly into the gasoline or diesel pools [280]. If functionalized aromatics are the desired commodities, a fraction of the first-stage product may be rerouted to another conditioning/separation route, for the production of monomers for the petrochemical, pharmaceutical, polymer, and resin industries [281-285].

The production of sugar and anhydrous ethanol from the processing of sugarcane generates high amounts of bagasse, a lignocellulosic residue. The integration of a thermochemical conversion unit parallel to the main refinery may allow for an expanded range of products including fuels and chemicals. The annual availability of sugarcane bagasse is discussed in Section 2.2, and a scheme of the integrated concept is shown in Figure 20.

Hydrotreatment requires the supply of large amounts of hydrogen gas, a fact that must be taken into account when designing a biorefinery concept. The current state-of-the-art technology produces $\mathrm{H}_{2}$ using steam reforming of natural gas, but HDT gas and biomass gasification may be feasible hydrogen sources [108,214,286,287]. Furthermore, $\mathrm{H}_{2}$ can also be sustainably produced by the hydrolysis of water, using renewable electricity sources, thus valorizing the aqueous condensate of fast pyrolysis [189]. 


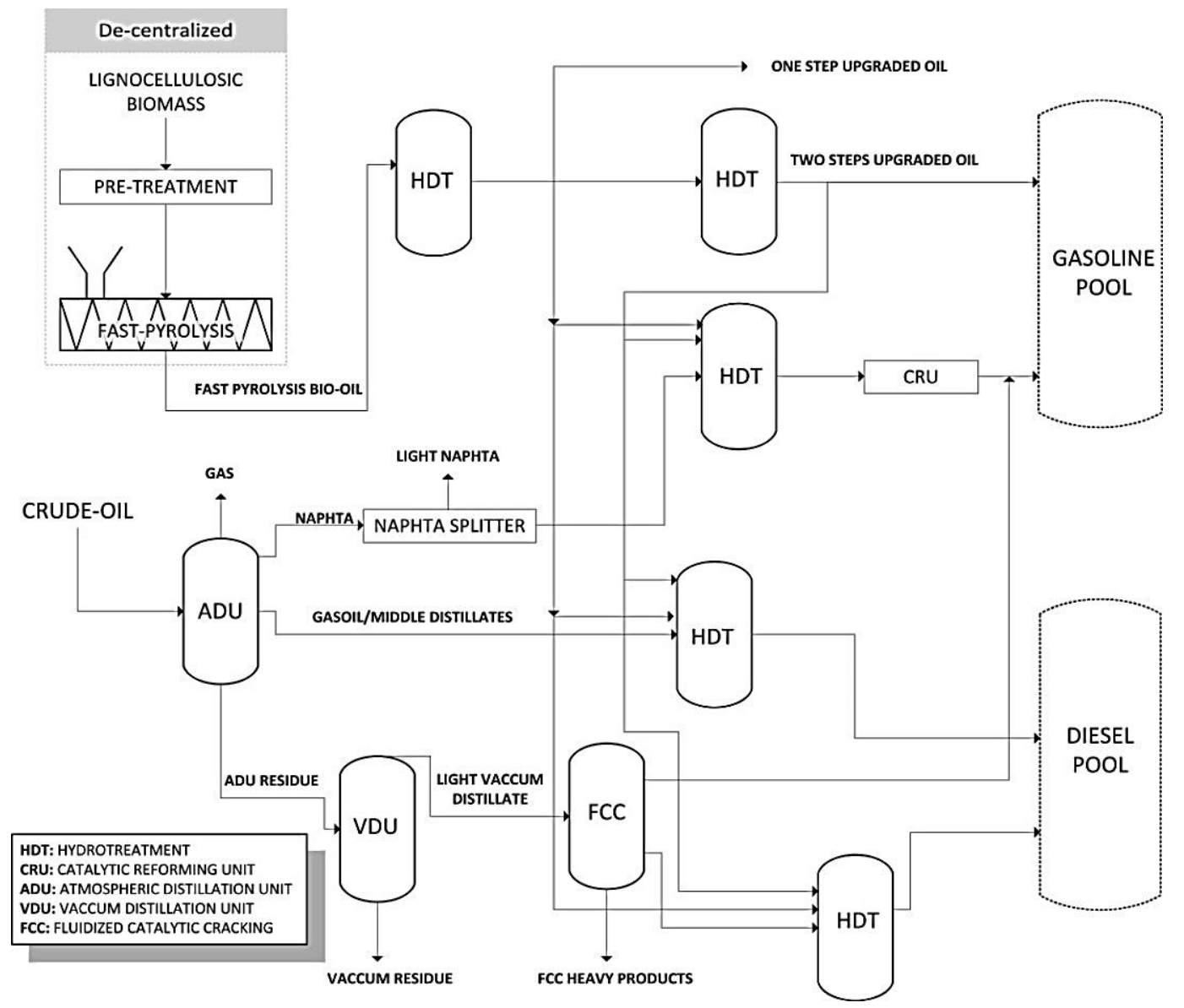

Figure 19. Diagram representing the de-centralized production of fast pyrolysis bio-oil and the integration with bio-oil refining. The 2-step upgrading of fast pyrolysis bio-oil can be performed in a single 2-zone stage HDT reactor, here represented as two individual HDT units.

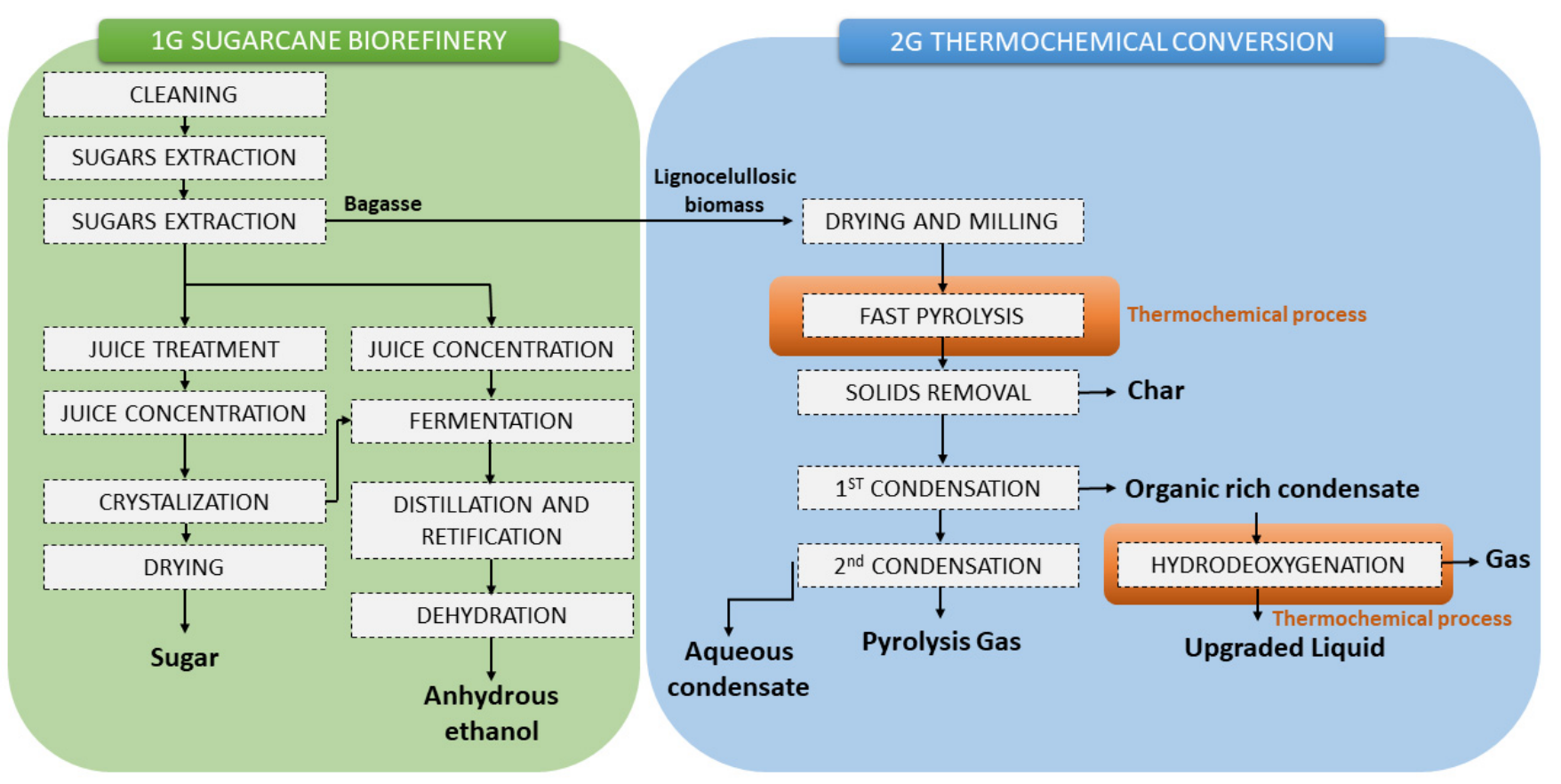

Figure 20. Integration of thermochemical conversion route into the sugarcane biorefinery. Adapted with permission from Schmitt et al. [137] (2020). Copyright 2020 Copyright Elsevier. 
Significant effort must be invested into meeting the challenges of the development, integration, and operation of biomass-based biorefinery concepts, namely when employing residual lignocellulosic biomasses. These challenges include the natural variability of properties associated with the use of biomass, the cost of producing a stable homogeneous FPBO with minimal inorganic content, and the selection/cost of upgrading techniques, depending on the final range of products desired. Other relevant challenges include the stability of oil during storage, the lack of robust catalysts for hydrotreatment, and the need for further investigation of continuous operation and product separation.

\section{Summary and Conclusions}

The social, political, and economic impact of the current period of anthropogenic climate change has been further exacerbated by the COVID-19 pandemic of 2020/21. Social distancing in several countries disproportionately negatively affected the low socioeconomic strata of the population throughout the world and reduced the sustainability of consumption patterns and energy production while reducing the pollution production associated with personal transportation.

Biorefineries centered on thermochemical conversion methods, such as pyrolysis, are a proven method for producing energy or platform chemicals using residues, mostly biomass but increasingly plastic and mixed residues, as a renewable feedstock. The direct production of liquid products, which can be further refined or employed directly, as well as the low cost of feedstock that does not require pretreatment, lead to thermochemical conversion methods that are competitive with biochemical conversion. The investment in biorefineries also leads to the generation of jobs and the revitalization of local economies currently based on agriculture, while contributing to the economic independence of a country or community.

The contribution of agriculture to the Brazilian economy is impossible to disregard, and the volume of residues generated can further increase the manufacture of secondgeneration bioproducts, thus reducing the environmental impacts of agricultural activity, such as deforestation, while further valorizing this economic sector. However, pyrolysis liquid produced from biomass is highly oxygenated, thus hindering its long-term stability and usability as a fuel of a feedstock for further treatment. Upgrading using catalytic hydrogenation appreciably reduces the heteroatom content in the bio-oil, and several recent studies aimed at the use of nickel and niobium, both abundant in Brazil, as low-cost alternatives to commercial catalysts further reinforce the potential for synergy between different economic sectors within the country.

Author Contributions: Conceptualization, C.C.S.; Writing—original draft preparation, C.C.S.; F.G.F.; M.M.C.F.; A.W.J.; S.K.; Á.H.M.J.; R.M.; D.E.H.; Writing-review and editing, C.C.S.; F.G.F.; Supervision, R.C.L.B.R.; K.R.; N.D.; Project Administration, C.C.S. All authors have read and agreed to the published version of the manuscript.

Funding: This research receives external funding from the State of São Paulo, Brazil, for the development of the scientific cooperation agreement signed between IKFT-KIT and IPT on 29 June 2020.

Acknowledgments: The work is part of a cooperation network Brazil-Germany led by Karlsruhe Institute of Technology, Federal University of Sergipe (UFS), University of São Paulo (USP), and Institute for Technological Research (IKFT-KIT). Therefore the authors acknowledge IPT, IKFT-KIT, USP, UFS, UFPR, CNPq, BBW ForWerts Bioeconomy Graduate Program, and the CAPES Foundation. We also acknowledge support by the KIT-Publication Fund of the Karlsruhe Institute of Technology.

Conflicts of Interest: The authors declare no conflict of interest.

\section{References}

1. BBC COVID Map: Coronavirus Cases, Deaths, Vaccinations by Country. Available online: https://www.bbc.com/news/world51235105 (accessed on 3 December 2021).

2. Desemprego vai Crescer no Mundo, Mas Subirá Ainda Mais no Brasil. Available online: https://www.cnnbrasil.com.br/ business/desemprego-vai-crescer-no-mundo-mas-subira-ainda-mais-no-brasil/ (accessed on 9 November 2021). 
3. Dickon, P.; Rogers, M.; Samandari, H. Quarterly Reports: Addressing Climate Change Post-Coronavirus. Available online: https://www.mckinsey.com/business-functions/sustainability/our-insights/addressing-climate-change-in-a-postpandemic-world\# (accessed on 9 November 2021).

4. Chiaramonti, D.; Maniatis, K. Security of supply, strategic storage and COVID19: Which lessons learnt for renewable and recycled carbon fuels, and their future role in decarbonizing transport? Appl. Energy 2020, 271, 115216. [CrossRef]

5. Magalhães, A.I.; Carvalho, J.C.; Melo Pereira, G.V.; Karp, S.G.; Câmara, M.C.; Medina, J.D.C.; Soccol, C.R. Lignocellulosic biomass from agro-industrial residues in South America: Current developments and perspectives. Biofuels Bioprod. Biorefining 2019, 13, 1505-1519. [CrossRef]

6. United Nations Green Economy Could Create 24 Million New Jobs. Available online: https://www.un.org/sustainabledevelopment/ blog/2019/04/green-economy-could-create-24-million-new-jobs/ (accessed on 9 November 2021).

7. IRENA; IEA Bioenergy. FAO Bioenergy for Sustainable Development. 2017. Available online: https://www.ieabioenergy.com/ blog/publications / bioenergy-for-sustainable-development/ (accessed on 4 December 2021).

8. Anwar, Z.; Gulfraz, M.; Irshad, M. Agro-industrial lignocellulosic biomass a key to unlock the future bio-energy: A brief review. J. Radiat. Res. Appl. Sci. 2014, 7, 163-173. [CrossRef]

9. Mohan, D.; Pittman, C.U.; Steele, P.H. Pyrolysis of wood/biomass for bio-oil: A critical review. Energy Fuels 2006, 20, 848-889. [CrossRef]

10. Xu, F.; Yu, J.; Tesso, T.; Dowell, F.; Wang, D. Qualitative and quantitative analysis of lignocellulosic biomass using infrared techniques: A mini-review. Appl. Energy 2013, 104, 801-809. [CrossRef]

11. Oasmaa, A.; Fonts, I.; Pelaez-Samaniego, M.R.; Garcia-Perez, M.E.M.; Garcia-Perez, M.E.M. Pyrolysis Oil Multiphase Behavior and Phase Stability: A Review. Energy Fuels 2016, 30, 6179-6200. [CrossRef]

12. Collard, F.X.; Blin, J. A review on pyrolysis of biomass constituents: Mechanisms and composition of the products obtained from the conversion of cellulose, hemicelluloses and lignin. Renew. Sustain. Energy Rev. 2014, 38, 594-608. [CrossRef]

13. Funke, A.; Tomasi Morgano, M.; Leibold, H.; Dahmen, N.; Leibold, H. Experimental comparison of two bench scale units for fast and intermediate pyrolysis. J. Anal. Appl. Pyrolysis 2017, 124, 504-514. [CrossRef]

14. James, A.K.; Thring, R.W.; Helle, S.; Ghuman, H.S. Ash management review-applications of biomass bottom ash. Energies 2012, 5, 3856-3873. [CrossRef]

15. Hayes, D.J.M. Second-generation biofuels: Why they are taking so long. Wiley Interdiscip. Rev. Energy Environ. 2013, 2, 304-334. [CrossRef]

16. Tripathi, M.; Sahu, J.N.; Ganesan, P. Effect of process parameters on production of biochar from biomass waste through pyrolysis: A review. Renew. Sustain. Energy Rev. 2016, 55, 467-481. [CrossRef]

17. Alam, F.; Mobin, S.; Chowdhury, H. Third Generation Biofuel from Algae. Procedia Eng. 2015, 105, 763-768. [CrossRef]

18. Goyal, H.B.; Seal, D.; Saxena, R.C. Bio-fuels from thermochemical conversion of renewable resources: A review. Renew. Sustain. Energy Rev. 2008, 12, 504-517. [CrossRef]

19. Welfle, A. Balancing growing global bioenergy resource demands-Brazil's biomass potential and the availability of resource for trade. Biomass Bioenergy 2017, 105, 83-95. [CrossRef]

20. Bonassa, G.; Schneider, L.T.; Canever, V.B.; Cremonez, P.A.; Frigo, E.P.; Dieter, J.; Teleken, J.G. Scenarios and prospects of solid biofuel use in Brazil. Renew. Sustain. Energy Rev. 2018, 82, 2365-2378. [CrossRef]

21. IBGE. Levantamento Sistemático da Produção Agrícola. 2020. Available online: https://www.ibge.gov.br/estatisticas/ economicas /agricultura-e-pecuaria/9201-levantamento-sistematico-da-producao-agricola.html (accessed on 4 December 2021).

22. Brainer, M.S.C.P. Produção de Coco: O Nordeste é Destaque Nacional. 2018. Available online: https://www.bnb.gov.br/ documents / 80223/4296541/61_coco.pdf/c172dd8f-3044-f1db-5d0c-a94c5eb735e0 (accessed on 4 December 2021).

23. Kumari, S.; Das, D. Biohythane production from sugarcane bagasse and water hyacinth: A way towards promising green energy production. J. Clean. Prod. 2019, 207, 689-701. [CrossRef]

24. Philippini, R.R.; Martiniano, S.E.; Chandel, A.K.; de Carvalho, W.; da Silva, S.S. Pretreatment of Sugarcane Bagasse from Cane Hybrids: Effects on Chemical Composition and 2G Sugars Recovery. Waste Biomass Valorization 2019, 10, 1561-1570. [CrossRef]

25. Dai, L.; Wang, Y.; Liu, Y.; Ruan, R.; Duan, D.; Zhao, Y.; Yu, Z.; Jiang, L. Catalytic fast pyrolysis of torrefied corn cob to aromatic hydrocarbons over Ni-modified hierarchical ZSM-5 catalyst. Bioresour. Technol. 2019, 272, 407-414. [CrossRef]

26. Stachowiak-Wencek, A.; Zborowska, M.; Waliszewska, H.; Waliszewska, B. Chemical changes in Lignocellulosic Biomass (Corncob) influenced by pretreatment and Anaerobic Digestion (AD). BioResources 2019, 14, 8082-8099.

27. Shao, X.; Wang, J.; Liu, Z.; Hu, N.; Liu, M.; Xu, Y. Preparation and Characterization of Porous Microcrystalline Cellulose from Corncob. Ind. Crops Prod. 2020, 151, 1-6. [CrossRef]

28. Cutrim, F.M.; Ramos, E.C.S.S.; Abreu, M.C.C.; Godinho, A.S.; Maciel, A.P.; Mendonça, C.J.S.; Cavalcante, K.S.B. A study of chemical composition and enzymatic hydrolysis of solid organic waste from agrosilvopastoral systems. J. Braz. Chem. Soc. 2019, 30, 1955-1963. [CrossRef]

29. de Paranhos, A.G.O.; Adarme, O.F.H.; Barreto, G.F.; de Silva, S.Q.; de Aquino, S.F. Methane production by co-digestion of poultry manure and lignocellulosic biomass: Kinetic and energy assessment. Bioresour. Technol. 2020, 300, 122588. [CrossRef] [PubMed]

30. Pocan, P.; Bahcegul, E.; Oztop, M.H.; Hamamci, H. Enzymatic Hydrolysis of Fruit Peels and Other Lignocellulosic Biomass as a Source of Sugar. Waste Biomass Valorization 2018, 9, 929-937. [CrossRef] 
31. Borges, T.E.; Almeida, J.H.S.; Amico, S.C.; Amado, F.D.R. Hollow glass microspheres/piassava fiber-reinforced homo- and co-polypropylene composites: Preparation and properties. Polym. Bull. 2017, 74, 1979-1993. [CrossRef]

32. d'Almeida, J.R.M.; Aquino, R.C.M.P.; Monteiro, S.N. Tensile mechanical properties, morphological aspects and chemical characterization of piassava (Attalea funifera) fibers. Compos. Part A Appl. Sci. Manuf. 2006, 37, 1473-1479. [CrossRef]

33. Daud, Z.; Sari, A.; Kassim, M.; Aripin, A.M.; Awang, H.; Hatta, Z.M.; Education, V.; Tun, U.; Onn, H.; Pahat, B. Chemical Composition and Morphological of Cocoa Pod Husks and Cassava Peels for Pulp and Paper Production. Aust. J. Basic Appl. Sci. 2013, 7, 406-411.

34. Aripin, A.M. Cassava Peels for Alternative Fibre in Pulp and Paper Industry: Chemical Properties and Morphology Characterization. Int. J. Integr. Eng. 2013, 5, 30-33.

35. Abiaziem, C.V.; Williams, A.B.; Inegbenebor, A.I.; Onwordi, C.T.; Petrik, L.F.; Land, C.; State, O.; Federal, T.; Ilaro, P.; State, O.; et al. Preparation, Characterisation and Physicochemical Properties of Cellulose Nanocrystals from Cassava Peel. In Proceedings of the 14th International Conference on Materials Chemistry (MC14), Birmingham, UK, 8-11 July 2019.

36. Cheng, J.; Zhang, J.; Lin, R.; Liu, J.; Zhang, L.; Cen, K. Ionic-liquid pretreatment of cassava residues for the cogeneration of fermentative hydrogen and methane. Bioresour. Technol. 2017, 228, 348-354. [CrossRef] [PubMed]

37. Jin, Y.; Huang, T.; Geng, W.; Yang, L. Comparison of sodium carbonate pretreatment for enzymatic hydrolysis of wheat straw stem and leaf to produce fermentable sugars. Bioresour. Technol. 2013, 137, 294-301. [CrossRef]

38. Mancini, G.; Papirio, S.; Lens, P.N.L.; Esposito, G. Increased biogas production from wheat straw by chemical pretreatments. Renew. Energy 2018, 119, 608-614. [CrossRef]

39. Lu, X.; Li, C.; Zhang, S.; Wang, X.; Zhang, W.; Wang, S.; Xia, T. Enzymatic sugar production from elephant grass and reed straw through pretreatments and hydrolysis with addition of thioredoxin-His-S. Biotechnol. Biofuels 2019, 12, 1-11. [CrossRef]

40. Espinosa, E.; Sánchez, R.; Otero, R.; Domínguez-Robles, J.; Rodríguez, A. A comparative study of the suitability of different cereal straws for lignocellulose nanofibers isolation. Int. J. Biol. Macromol. 2017, 103, 990-999. [CrossRef]

41. Gao, Y.; Guo, X.; Liu, Y.; Fang, Z.; Zhang, M.; Zhang, R.; You, L.; Li, T.; Liu, R.H. A full utilization of rice husk to evaluate phytochemical bioactivities and prepare cellulose nanocrystals. Sci. Rep. 2018, 8, 1-8. [CrossRef]

42. Sajith, S.; Arumugam, V.; Dhakal, H.N. Comparison on mechanical properties of lignocellulosic flour epoxy composites prepared by using coconut shell, rice husk and teakwood as fillers. Polym. Test. 2017, 58, 60-69. [CrossRef]

43. Rambo, M.K.D.; Schmidt, F.L.; Ferreira, M.M.C. Analysis of the lignocellulosic components of biomass residues for biorefinery opportunities. Talanta 2015, 144, 696-703. [CrossRef] [PubMed]

44. Gomes, H.A.R.; da Silva, A.J.; Gómez-Mendoza, D.P.; dos Santos Júnior, A.C.M.; de di Cologna, N.M.; Almeida, R.M.; Miller, R.N.G.; Fontes, W.; de Sousa, M.V.; Ricart, C.A.O.; et al. Identification of multienzymatic complexes in the Clonostachys byssicola secretomes produced in response to different lignocellulosic carbon sources. J. Biotechnol. 2017, 254, 51-58. [CrossRef]

45. Orozco, R.S.; Hernández, P.B.; Morales, G.R.; Núñez, F.U.; Villafuerte, J.O.; Lugo, V.L.; Ramírez, N.F.; Díaz, C.E.B.; Vázquez, P.C. Characterization of lignocellulosic fruit waste as an alternative feedstock for bioethanol production. BioResources 2014, 9 , 1873-1885.

46. Arisht, S.N.; Abdul, P.M.; Liu, C.M.; Lin, S.K.; Maaroff, R.M.; Wu, S.Y.; Jahim, J.M. Biotoxicity assessment and lignocellulosic structural changes of phosphoric acid pre-treated young coconut husk hydrolysate for biohydrogen production. Int. J. Hydrogen Energy 2019, 44, 5830-5843. [CrossRef]

47. Teixeira, J.N.; Silva, D.W.; Vilela, A.P.; Savastano Junior, H.; de Siqueira Brandão Vaz, L.E.V.; Mendes, R.F. Lignocellulosic Materials for Fiber Cement Production. Waste Biomass Valorization 2020, 11, 2193-2200. [CrossRef]

48. Toscan, A.; Fontana, R.C.; Andreaus, J.; Camassola, M.; Lukasik, R.M.; Dillon, A.J.P. New two-stage pretreatment for the fractionation of lignocellulosic components using hydrothermal pretreatment followed by imidazole delignification: Focus on the polysaccharide valorization. Bioresour. Technol. 2019, 285, 121346. [CrossRef] [PubMed]

49. da Silva, S.B.; Arantes, M.D.C.; de Andrade, J.K.B.; Andrade, C.R.; de Carneiro, A.C.O.; de Protásio, T.P. Influence of physical and chemical compositions on the properties and energy use of lignocellulosic biomass pellets in Brazil. Renew. Energy 2020, 147, 1870-1879. [CrossRef]

50. Vintila, T.; Negrea, A.; Barbu, H.; Sumalan, R.; Kovacs, K. Metal distribution in the process of lignocellulosic ethanol production from heavy metal contaminated sorghum biomass. J. Chem. Technol. Biotechnol. 2016, 91, 1607-1614. [CrossRef]

51. Pengilly, C.; García-Aparicio, M.; Swart, J.P.J.; Görgens, J.F. Micro-assay method for enzymatic saccharification of industrially relevant lignocellulose substrates. Biomass Convers. Biorefinery 2020. Available online: https://link.springer.com/article/10.1007/ s13399-020-00700-6 (accessed on 4 December 2020). [CrossRef]

52. Chen, B.; Luo, Z.; Chen, H.; Chen, C.; Cai, D.; Qin, P.; Cao, H.; Tan, T. Wood Plastic Composites from the Waste Lignocellulosic Biomass Fibers of Bio-Fuels Processes: A Comparative Study on Mechanical Properties and Weathering Effects. Waste Biomass Valorization 2020, 11, 1701-1710. [CrossRef]

53. Guerfali, M.; Ayadi, I.; Belhassen, A.; Gargouri, A.; Belghith, H. Single cell oil production by Trichosporon cutaneum and lignocellulosic residues bioconversion for biodiesel synthesis. Process Saf. Environ. Prot. 2018, 113, 292-304. [CrossRef]

54. Cai, J.; He, Y.; Yu, X.; Banks, S.W.; Yang, Y.; Zhang, X.; Yu, Y.; Liu, R.; Bridgwater, A.V. Review of physicochemical properties and analytical characterization of lignocellulosic biomass. Renew. Sustain. Energy Rev. 2017, 76, 309-322. [CrossRef] 
55. Companhia Nacional de Abastecimento-CONAB. Acompanhamento de Safra Brasileira de Cana-de-Açúcar; CONAB: Brasília, Brazil, 2020; Volume 7. Available online: https:/ / www.conab.gov.br/info-agro/safras/cana (accessed on 3 November 2020).

56. Santucci, B.S. Estudo dos Efeitos dos Tratamentos Físico- Mecânicos Na Hidrólise Da Celulose do Bagaço de Cana-de-Açúcar; Universidade de São Paulo: São Paulo, Brasil, 2018.

57. Santos, F.; Diola, V. Physiology. In Sugarcane: Agricultural Production, Bioenergy and Ethanol; Fernando, S., Aluízio Borém, C.C., Eds.; Academic Press: Cambridge, MA, USA, 2015; pp. 13-33, ISBN 9780128022399.

58. Cortez, L.A.B.; Baldassin, R.; De Almeida, E. Energy from sugarcane. In Sugarcane Biorefinery, Technology and Perspectives; Fernando, S., Sarita, C.R., De Matos Mario, P.E., Eds.; Academic Press: Cambridge, MA, USA, 2019; pp. 117-139, ISBN 9780128142363.

59. Santos, F.; Eichler, P.; Machado, G.; De Mattia, J.; De Souza, G. By-products of the sugarcane industry. In Sugarcane Biorefinery, Technology and Perspectives; Santos, F., Rabelo, S.C., De Matos, M., Eichler, P., Eds.; Academic Press: Cambridge, MA, USA, 2019; pp. 21-48, ISBN 9780128142363.

60. Assad, L. Aproveitamento de resíduos do setor sucroalcooleiro desafia empresas e pesquisadores. Cienc. Cult. 2017, 69, 13-16. [CrossRef]

61. Hojo, L.Y.C.P.; Ajala, E.; Neto, A.G.; Martins, C.H.; de Angelis Neto, C.G.; Regina, G.T. Diagóstico do gerenciamento dos resíduos em uma indústria sucroalcooleira. In Proceedings of the Anais do III Simpósio de Pós-Graduação em Engenharia Urbana (SIMPGEU), Maringá, Brazil, 7-8 November 2012; pp. 1-9.

62. Antonio Bizzo, W.; Lenço, P.C.; Carvalho, D.J.; Veiga, J.P.S. The generation of residual biomass during the production of bioethanol from sugarcane, its characterization and its use in energy production. Renew. Sustain. Energy Rev. 2014, $29,589-603$. [CrossRef]

63. Díaz Pérez, Á.A.; Escobar Palacio, J.C.; Venturini, O.J.; Martínez Reyes, A.M.; Rúa Orozco, D.J.; Silva Lora, E.E.; del Olmo Almazán, O.A. Thermodynamic and economic evaluation of reheat and regeneration alternatives in cogeneration systems of the Brazilian sugarcane and alcohol sector. Energy 2018, 152, 247-262. [CrossRef]

64. Alves, M. Estudo de Sistemas de Cogeração em Usinas de Açúcar e Álcool, Com Utilização do Bagaço e Palha da Cana; Universidade Estadual de Campinas: Campinas, Brazil, 2011.

65. Smithers, J. Review of sugarcane trash recovery systems for energy cogeneration in South Africa. Renew. Sustain. Energy Rev. 2014, 32, 915-925. [CrossRef]

66. Mutran, V.M.; Ribeiro, C.O.; Nascimento, C.A.O; Chachuat, B. Risk-conscious optimization model to support bioenergy investments in the Brazilian sugarcane industry. Appl. Energy 2020, 258, 113978. [CrossRef]

67. Kanwal, S.; Chaudhry, N.; Munir, S.; Sana, H. Effect of torrefaction conditions on the physicochemical characterization of agricultural waste (sugarcane bagasse). Waste Manag. 2019, 88, 280-290. [CrossRef]

68. Gong, S.H.; Im, H.S.; Um, M.; Lee, H.W.; Lee, J.W. Enhancement of waste biomass fuel properties by sequential leaching and wet torrefaction. Fuel 2019, 239, 693-700. [CrossRef]

69. Cahyanti, M.N.; Doddapaneni, T.R.K.C.; Kikas, T. Biomass torrefaction: An overview on process parameters, economic and environmental aspects and recent advancements. Bioresour. Technol. 2020, 301, 122737. [CrossRef] [PubMed]

70. Redação Jornal da Cana Das 20 Maiores Usinas de Cana, só 9 Têm Lucro Positive. Available online: https://jornalcana.com.br/ das-20-maiores-usinas-de-cana-so-9-tem-lucro-positivo/ (accessed on 19 May 2021).

71. Relatório de Sustentabilidade-Comunicação de Progresso Safra 2019/2020, Maringá, PA, Brazil. 2020. Available online: https: //www.usacucar.com.br/conteudos.php?local=index\&id=32 (accessed on 4 December 2021).

72. Copersucar Relatório de Sustentabilidade 2016-2018. Available online: http:/ / relatorios.copersucar.com.br/2018/inicio1.html (accessed on 19 May 2021).

73. Relatório de Sustentabilidade 2018, São Manoel, SP, Brazil. 2019. Available online: https://www.saomanoel.com.br (accessed on 9 June 2021).

74. Usina Batatais Processo Produtivo-Reutilização de Recursos. Available online: http://www.usinabatatais.com.br/programassocioambientais-e-culturais/processo-produtivo-reutilizacao-de-recursos.html (accessed on 17 May 2021).

75. Plano de Gestão de Impacto Ambiental Grupo Balbo. Available online: https:/ /www.canaverde.com.br/wp-content/uploads/ 2020/09/Usina-Uberaba-EIMP-Resumo-2020-1.pdf (accessed on 9 June 2021).

76. Relatório de Sustentabilidade 2019 Adecoagro. Available online: https://sustainability.adecoagro.com/storage/documents / 2019 -br.pdf (accessed on 9 June 2021).

77. Usina São João Technical Report. Available online: https:/ / site.usj.com.br/site (accessed on 9 June 2021).

78. Terán Hilares, R.; Swerts, M.P.; Ahmed, M.A.; Ramos, L.; da Silva, S.S.; Santos, J.C. Organosolv Pretreatment of Sugar Cane Bagasse for Bioethanol Production. Ind. Eng. Chem. Res. 2017, 56, 3833-3838. [CrossRef]

79. Mesa, L.; González, E.; Cara, C.; González, M.; Castro, E.; Mussatto, S.I. The effect of organosolv pretreatment variables on enzymatic hydrolysis of sugarcane bagasse. Chem. Eng. J. 2011, 168, 1157-1162. [CrossRef]

80. da Gomes, A.C.; Rodrigues, M.I.; de França Passos, D.; Machado de Castro, A.; Maria Mello Santa Anna, L.; Pereira, N. Acetonebutanol-ethanol fermentation from sugarcane bagasse hydrolysates: Utilization of C5 and C6 sugars. Electron. J. Biotechnol. 2019, 42, 16-22. [CrossRef] 
81. de Guilherme, A.A.; Dantas, P.V.F.; de Padilha, C.E.A.; dos Santos, E.S.; de Macedo, G.R. Ethanol production from sugarcane bagasse: Use of different fermentation strategies to enhance an environmental-friendly process. J. Environ. Manage. 2019, 234, 44-51. [CrossRef]

82. Salomão, G.S.B.; Agnezi, J.C.; Paulino, L.B.; Hencker, L.B.; de Lira, T.S.; Tardioli, P.W.; Pinotti, L.M. Production of cellulases by solid state fermentation using natural and pretreated sugarcane bagasse with different fungi. Biocatal. Agric. Biotechnol. 2019, 17, 1-6. [CrossRef]

83. Berenguer, R.A.; Capraro, A.P.B.; de Medeiros, M.H.F.; Carneiro, A.M.P.; De Oliveira, R.A. Sugar cane bagasse ash as a partial substitute of Portland cement: Effect on mechanical properties and emission of carbon dioxide. J. Environ. Chem. Eng. 2020, 8, 103655. [CrossRef]

84. de Mello, L.C.A.; dos Anjos, M.A.S.; de Sá, M.V.V.A.; de Souza, S.L.N.; de Farias, E.C. Effect of high temperatures on selfcompacting concrete with high levels of sugarcane bagasse ash and metakaolin. Constr. Build. Mater. 2020, $248,118715$. [CrossRef]

85. Oliveira, J.A.; Cunha, F.A.; Ruotolo, L.A.M. Synthesis of zeolite from sugarcane bagasse fly ash and its application as a low-cost adsorbent to remove heavy metals. J. Clean. Prod. 2019, 229, 956-963. [CrossRef]

86. Jacob, M.M.; Ponnuchamy, M.; Kapoor, A.; Sivaraman, P. Bagasse based biochar for the adsorptive removal of chlorpyrifos from contaminated water. J. Environ. Chem. Eng. 2020, 8, 103904. [CrossRef]

87. Akinfalabi, S.-I.; Rashid, U.; Ngamcharussrivichai, C.; Nehdi, I.A. Synthesis of reusable biobased nano-catalyst from waste sugarcane bagasse for biodiesel production. Environ. Technol. Innov. 2020, 18, 100788. [CrossRef]

88. Bridgwater, A. Renewable fuels and chemicals by thermal processing of biomass. Chem. Eng. J. 2003, 91, 87-102. [CrossRef]

89. Dahmen, N.; Lewandowski, I.; Zibek, S.; Weidtmann, A. Integrated lignocellulosic value chains in a growing bioeconomy: Status quo and perspectives. GCB Bioenergy 2019, 11, 107-117. [CrossRef]

90. Xiu, S.; Shahbazi, A. Bio-oil production and upgrading research: A review. Renew. Sustain. Energy Rev. 2012, 16, 4406-4414. [CrossRef]

91. Kan, T.; Strezov, V.; Evans, T.J. Lignocellulosic biomass pyrolysis: A review of product properties and effects of pyrolysis parameters. Renew. Sustain. Energy Rev. 2016, 57, 126-1140. [CrossRef]

92. Bridgwater, A.V.V. Review of fast pyrolysis of biomass and product upgrading. Biomass Bioenergy 2012, 38, 68-94. [CrossRef]

93. Pfitzer, C.; Dahmen, N.; Tröger, N.; Weirich, F.; Sauer, J.; Günther, A.; Müller-Hagedorn, M. Fast Pyrolysis of Wheat Straw in the Bioliq Pilot Plant. Energy Fuels 2016, 30, 8047-8054. [CrossRef]

94. Polin, P.J.; Carr, D.H.; Whitmer, L.E.; Smith, R.G.; Brown, R.C. Conventional and autothermal pyrolysis of corn stover: Overcoming the processing challenges of high-ash agricultural residues. J. Anal. Appl. Pyrolysis 2019, 143, 104679. [CrossRef]

95. Basu, P. Biomass Gasification and Pyrolysis: Practical Design and Theory; Elsevier: Amsterdam, The Netherlands, 2010; ISBN 978-0-12-374988-8.

96. Van de Velden, M.; Baeyens, J.; Brems, A.; Janssens, B.; Dewil, R. Fundamentals, kinetics and endothermicity of the biomass pyrolysis reaction. Renew. Energy 2010, 35, 232-242. [CrossRef]

97. Guedes, R.E.; Luna, A.S.; Torres, A.R. Operating parameters for bio-oil production in biomass pyrolysis: A review. J. Anal. Appl. Pyrolysis 2018, 129, 134-149. [CrossRef]

98. Fonseca, F.G.; Funke, A.; Niebel, A.; Soares Dias, A.P.; Dahmen, N. Moisture content as a design and operational parameter for fast pyrolysis. J. Anal. Appl. Pyrolysis 2019, 139, 73-86. [CrossRef]

99. Demirbas, A.; Arin, G. An Overview of Biomass Pyrolysis. Energy Sources 2002, 24, 471-482. [CrossRef]

100. IEA Bioenergy Pyrolysis Reactors. Available online: http://task34.ieabioenergy.com/pyrolysis-reactors/ (accessed on 4 December 2019).

101. Park, J.; Meng, J.; Lim, K.H.; Rojas, O.J.; Park, S. Transformation of lignocellulosic biomass during torrefaction. J. Anal. Appl. Pyrolysis 2013, 100, 199-206. [CrossRef]

102. Dahmen, N. Lecture: Energy from Biomass; Karlsruhe Institute of Technology: Karlsruhe, Germany, 2019.

103. Oasmaa, A.; Solantausta, Y.; Arpiainen, V.; Kuoppala, E.; Sipilä, K. Fast pyrolysis bio-oils from wood and agricultural residues. Energy Fuels 2010, 24, 1380-1388. [CrossRef]

104. Fahmi, R.; Bridgwater, A.V.; Donnison, I.; Yates, N.; Jones, J.M. The effect of lignin and inorganic species in biomass on pyrolysis oil yields, quality and stability. Fuel 2008, 87, 1230-1240. [CrossRef]

105. Di Blasi, C. Modeling chemical and physical processes of wood and biomass pyrolysis. Prog. Energy Combust. Sci. 2008, 34, 47-90. [CrossRef]

106. Yang, H.; Yan, R.; Chen, H.; Lee, D.H.; Zheng, C. Characteristics of hemicellulose, cellulose and lignin pyrolysis. Fuel 2007, 86, 1781-1788. [CrossRef]

107. Carrier, M.; Windt, M.; Ziegler, B.; Appelt, J.; Saake, B.; Meier, D.; Bridgwater, A. Quantitative Insights into the Fast Pyrolysis of Extracted Cellulose, Hemicelluloses, and Lignin. ChemSusChem 2017, 10, 3212-3224. [CrossRef] [PubMed]

108. Lédé, J. Cellulose pyrolysis kinetics: An historical review on the existence and role of intermediate active cellulose. J. Anal. Appl. Pyrolysis 2012, 94, 17-32. [CrossRef]

109. Gollakota, A.R.K.; Reddy, M.; Subramanyam, M.D.; Kishore, N. A review on the upgradation techniques of pyrolysis oil. Renew. Sustain. Energy Rev. 2016, 58, 1543-1568. [CrossRef] 
110. Westerhof, R.J.M.M.; Nygård, H.S.; Van Swaaij, W.P.M.M.; Kersten, S.R.A.A.; Brilman, D.W.F.F. Effect of particle geometry and microstructure on fast pyrolysis of beech wood. Energy Fuels 2012, 26, 2274-2280. [CrossRef]

111. Scott, D.S.; Piskorz, J. The flash pyrolysis of aspen-poplar wood. Can. J. Chem. Eng. 1982, 60, 666-674. [CrossRef]

112. Wang, X.; Kersten, S.R.A.; Prins, W.; Van Swaaij, W.P.M. Biomass pyrolysis in a fluidized bed reactor. Part 2: Experimental validation of model results. Ind. Eng. Chem. Res. 2005, 44, 8786-8795. [CrossRef]

113. Shen, J.; Wang, X.-S.; Garcia-Perez, M.; Mourant, D.; Rhodes, M.J.; Li, C.-Z. Effects of particle size on the fast pyrolysis of oil mallee woody biomass. Fuel 2009, 88, 1810-1817. [CrossRef]

114. Salehi, E.; Abedi, J.; Harding, T. Bio-oil from Sawdust: Effect of Operating Parameters on the Yield and Quality of Pyrolysis Products. Energy Fuels 2011, 25, 4145-4154. [CrossRef]

115. Demirbas, A. Effects of temperature and particle size on bio-char yield from pyrolysis of agricultural residues. J. Anal. Appl. Pyrolysis 2004, 72, 243-248. [CrossRef]

116. Luangkiattikhun, P.; Tangsathitkulchai, C.; Tangsathitkulchai, M. Non-isothermal thermogravimetric analysis of oil-palm solid wastes. Bioresour. Technol. 2008, 99, 986-997. [CrossRef]

117. Pütün, A.E.; Koçkar, Ö.M.; Yorgun, S.; Gerçel, H.F.; Andresen, J.; Snape, C.E.; Pütün, E. Fixed-bed pyrolysis and hydropyrolysis of sunflower bagasse: Product yields and compositions. Fuel Process. Technol. 1996, 46, 49-62. [CrossRef]

118. Kersten, S.R.A.; Wang, X.; Prins, W.; van Swaaij, W.P.M. Biomass Pyrolysis in a Fluidized Bed Reactor. Part 1: Literature Review and Model Simulations. Ind. Eng. Chem. Res. 2005, 44, 8773-8785. [CrossRef]

119. Di Blasi, C.; Branca, C. Temperatures of wood particles in a hot sand bed fluidized by nitrogen. Energy Fuels 2003, 17, 247-254. [CrossRef]

120. Chaiwat, W.; Hasegawa, I.; Tani, T.; Sunagawa, K.; Mae, K. Analysis of cross-linking behavior during pyrolysis of cellulose for elucidating reaction pathway. Energy Fuels 2009, 23, 5765-5772. [CrossRef]

121. Manyà, J.J.; Ruiz, J.; Arauzo, J. Some peculiarities of conventional pyrolysis of several agricultural residues in a packed bed reactor. Ind. Eng. Chem. Res. 2007, 46, 9061-9070. [CrossRef]

122. Font, R.; Marcilla, A.; Devesa, J.; Verdú, E. Gaseous hydrocarbons from flash pyrolysis of almond shells. Ind. Eng. Chem. Res. 1988, 27, 1143-1149. [CrossRef]

123. Haykiri-Acma, H. The role of particle size in the non-isothermal pyrolysis of hazelnut shell. J. Anal. Appl. Pyrolysis 2006, 75, 211-216. [CrossRef]

124. Jayaweera, S.A.A.; Moss, J.H.; Thwaites, M.W. The effect of particle size on the combustion of weardale coal. Thermochim. Acta 1989, 152, 215-225. [CrossRef]

125. Funazukuri, T.; Hudgins, R.R.; Silveston, P.L. Product distribution in pyrolysis of cellulose in a microfluidized bed. J. Anal. Appl. Pyrolysis 1986, 9, 139-158. [CrossRef]

126. Westerhof, R.J.M.; Brilman, D.W.F.; van Swaaij, W.P.M.; Kersten, S.R.A. Effect of Temperature in Fluidized Bed Fast Pyrolysis of Biomass: Oil Quality Assessment in Test Units. Ind. Eng. Chem. Res. 2010, 49, 1160-1168. [CrossRef]

127. Haas, T.J.; Nimlos, M.R.; Donohoe, B.S. Real-time and post-reaction microscopic structural analysis of biomass undergoing pyrolysis. Energy Fuels 2009, 23, 3810-3817. [CrossRef]

128. Teixeira, A.R.; Mooney, K.G.; Kruger, J.S.; Williams, C.L.; Suszynski, W.J.; Schmidt, L.D.; Schmidt, D.P.; Dauenhauer, P.J. Aerosol generation by reactive boiling ejection of molten cellulose. Energy Environ. Sci. 2011, 4, 4306. [CrossRef]

129. Zhou, S.; Garcia-Perez, M.; Pecha, B.; Kersten, S.R.A.; McDonald, A.G.; Westerhof, R.J.M. Effect of the fast pyrolysis temperature on the primary and secondary products of lignin. Energy Fuels 2013, 27, 5867-5877. [CrossRef]

130. Bridgeman, T.G.; Darvell, L.I.; Jones, J.M.; Williams, P.T.; Fahmi, R.; Bridgwater, A.V.; Barraclough, T.; Shield, I.; Yates, N.; Thain, S.C.; et al. Influence of particle size on the analytical and chemical properties of two energy crops. Fuel 2007, 86, 60-72. [CrossRef]

131. Krutof, A.; Hawboldt, K.A. Upgrading of biomass sourced pyrolysis oil review: Focus on co-pyrolysis and vapour upgrading during pyrolysis. Biomass Convers. Biorefinery 2018, 8, 775-787. [CrossRef]

132. Hoekstra, E.; Westerhof, R.J.M.; Brilman, W.; Van Swaaij, W.P.M.; Kersten, S.R.A.; Hogendoorn, K.J.A.; Windt, M. Heterogeneous and homogeneous reactions of pyrolysis vapors from pine wood. AIChE J. 2012, 58, 2830-2842. [CrossRef]

133. Kim, P.; Weaver, S.; Labbé, N. Effect of sweeping gas flow rates on temperature-controlled multistage condensation of pyrolysis vapors in an auger intermediate pyrolysis system. J. Anal. Appl. Pyrolysis 2016, 118, 325-334. [CrossRef]

134. Papari, S.; Hawboldt, K. A review on condensing system for biomass pyrolysis process. Fuel Process. Technol. 2018, 180, 1-13. [CrossRef]

135. Williams, P.T.; Brindle, A.J. Temperature selective condensation of tyre pyrolysis oils to maximise the recovery of single ring aromatic compounds. Fuel 2003, 82, 1023-1031. [CrossRef]

136. Johansson, A.C.; Iisa, K.; Sandström, L.; Ben, H.; Pilath, H.; Deutch, S.; Wiinikka, H.; Öhrman, O.G.W. Fractional condensation of pyrolysis vapors produced from Nordic feedstocks in cyclone pyrolysis. J. Anal. Appl. Pyrolysis 2017, 123, 244-254. [CrossRef]

137. Schmitt, C.C.; Moreira, R.; Neves, R.C.; Richter, D.; Funke, A.; Raffelt, K.; Grunwaldt, J.-D.; Dahmen, N. From agriculture residue to upgraded product: The thermochemical conversion of sugarcane bagasse for fuel and chemical products. Fuel Process. Technol. 2020, 197, 106199. [CrossRef]

138. Kornmayer, C. Verfahrenstechnik Untersuchungen zur Schnellpyrolyse von Lignocellulose im Doppenschnecken-Mischreaktor; Universität Fridericiana Karlsruhe: Karlsruhe, Germany, 2009.

139. Bridgwater, A. Fast pyrolysis processes for biomass. Renew. Sustain. Energy Rev. 2000, 4, 1-73. [CrossRef] 
140. Lappas, A.A.; Samolada, M.C.; Iatridis, D.K.; Voutetakis, S.S.; Vasalos, I.A. Biomass pyrolysis in a circulating fluid bed reactor for the production of fuels and chemicals. Fuel 2002, 81, 2087-2095. [CrossRef]

141. Lakshmanan, C.M.; Gal-Or, B.; Hoelscher, H.E. Production of Levoglucosan by Pyrolysis of Carbohydrates Pyrolysis. Ind. Eng. Chem. Prod. Res. Dev. 1969, 8, 261-264.

142. Campuzano, F.; Brown, R.C.; Martínez, J.D. Auger reactors for pyrolysis of biomass and wastes. Renew. Sustain. Energy Rev. 2019, 102, 372-409. [CrossRef]

143. Henrich, E.; Dahmen, N.; Weirich, F.; Reimert, R.; Kornmayer, C. Fast pyrolysis of lignocellulosics in a twin screw mixer reactor. Fuel Process. Technol. 2016, 143, 151-161. [CrossRef]

144. Badger, P.C.; Fransham, P. Use of mobile fast pyrolysis plants to densify biomass and reduce biomass handling costs-A preliminary assessment. Biomass Bioenergy 2006, 30, 321-325. [CrossRef]

145. Schulzke, T.; Conrad, S.; Westermeyer, J. Fractionation of flash pyrolysis condensates by staged condensation. Biomass Bioenergy 2016, 95, 287-295. [CrossRef]

146. Bech, N. In Situ Flash Pyrolysis of Straw; Technical University of Denmark: Copenhagen, Denmark, 2008.

147. Glaser, B. Prehistorically modified soils of central Amazonia: A model for sustainable agriculture in the twenty-first century. Philos. Trans. R. Soc. B Biol. Sci. 2007, 362, 187-196. [CrossRef]

148. Anderson, P.S. Introduction to the Rotatable Covered Cavity (RoCC) Kiln for Medium-Size Production of Pyrolytic Biochar and Thermal Energy. Available online: https://woodgas.com/resources/ (accessed on 15 July 2020).

149. Worldwide, W.H. WarmHeart Worldwide. Available online: https:/ / warmheartworldwide.org/ (accessed on 4 December 2021).

150. Juntos NFP. Juntos NFP. Available online: https:/ /juntosnfp.org/ (accessed on 4 December 2021).

151. Meier, D.; Van De Beld, B.; Bridgwater, A.V.; Elliott, D.C.; Oasmaa, A.; Preto, F. State-of-the-art of fast pyrolysis in IEA bioenergy member countries. Renew. Sustain. Energy Rev. 2013, 20, 619-641. [CrossRef]

152. Bridgwater, A.V. The production of biofuels and renewable chemicals by fast pyrolysis of biomass. Int. J. Glob. Energy Issues 2007, 27, 160. [CrossRef]

153. Venderbosch, R.; Prins, W. Fast pyrolysis technology development. Biofuels Bioprod. Biorefining 2010, 4, 178-208. [CrossRef]

154. Garcia-Nunez, J.A.; Pelaez-Samaniego, M.R.; Garcia-Perez, M.E.; Fonts, I.; Abrego, J.; Westerhof, R.J.M.; Garcia-Perez, M. Historical Developments of Pyrolysis Reactors: A Review. Energy Fuels 2017, 31, 5751-5775. [CrossRef]

155. Oasmaa, A.; Peacocke, C. Properties and Fuel Use of Biomass-Derived Fast Pyrolysis Liquids. A Guide; VTT Publications: Espoo, Finland, 2010; Volume 731, ISBN 9789513873844.

156. Pirowiki Welcome to PyroWiki. Available online: http://pyrowiki.pyroknown.eu/index.php/Welcome_to_PyroWiki (accessed on 21 November 2021).

157. Peacocke, G.V.C. Ablative Pyrolysis of Biomass; Aston University: Birmingham, UK, 1994; Volume 7.

158. Austrian Federal Ministry of Education Science and Research Fixed bed lab-scale reactor. Available online: https: / / forschungsinfrastruktur.bmbwf.gv.at/en/fi/fixed-bed-lab-scale-reactor_3026 (accessed on 14 June 2021).

159. Soares Dias, A.P.; Rego, F.; Fonseca, F.; Casquilho, M.; Rosa, F.; Rodrigues, A. Catalyzed pyrolysis of SRC poplar biomass. Alkaline carbonates and zeolites catalysts. Energy 2019, 183, 1114-1122. [CrossRef]

160. Kaminsky, W.; Predel, M.; Sadiki, A. Feedstock recycling of polymers by pyrolysis in a fluidised bed. Polym. Degrad. Stab. 2004, 85, 1045-1050. [CrossRef]

161. Knight, J.A.; Gorton, C.W.; Kovac, R.J. Oil production by entrained flow pyrolysis of biomass. Biomass 1984, 6, 69-76. [CrossRef]

162. Funke, A.; Richter, D.; Niebel, A.; Dahmen, N.; Sauer, J. Fast Pyrolysis of Biomass Residues in a Twin-screw Mixing Reactor. J. Vis. Exp. 2016, 115, 1-8. [CrossRef] [PubMed]

163. Santana, K.V.R.; Apolônio, F.C.S.O.; Wisniewski, A., Jr. Valorization of cattle manure by thermoconversion process in a rotary kiln reactor to produce environmentally friendly products. BioEnergy Res. 2020, 13, 605-617. [CrossRef]

164. Berruti, F.F.; Briens, C.; Ferrante, L. A Mobile Pyrolyzer for Converting Agricultural and Forestry Residues into Liquid Bio-Oil and Bio-Char. In Proceedings of the CO2 Summit: Technology and Opportunity, Vail, CO, USA, 6-10 June 2010; Zhu, F., Ed.; UOP: Des Plaines, IL, USA, 2010.

165. Li, J.; Li, N.; Qiao, Y.; Zong, P.; Wang, C.; Tian, Y.; Qin, S. Biomass Pyrolysis Liquefaction Technique: State of Research and Development Trends. IOP Conf. Ser. Earth Environ. Sci. 2020, 558, 022016. [CrossRef]

166. Kaminsky, W. The Hamburg Fluidized-bed Pyrolysis Process to Recycle Polymer Wastes and Tires. In Feedstock Recycling and Pyrolysis of Waste Plastics; John Wiley \& Sons Ltd.: Chichester, UK, 2006; pp. 475-491.

167. Gust, S.; McLellan, R.J.; Meier, D.; Oasmaa, A.; Ormrod, D.; Peacocke, G.V.C. Determination of Norms and Standards for Biomass Fast Pyrolysis Liquids as an Alternative Renewable Fuel for Electricity and Heat Production; CPL Press: Cambridge, UK, 2005.

168. Conner, G.T.; Tyrrell-Baxter, F.J. Apparatus and Method for Processing Biomass (AU2012341144B2). IP Australia. 2017. Available online: https:/ / patents.google.com/patent/AU2012341144B2/en (accessed on 4 December 2021).

169. Vancouver Sun DynaMotive's Words Speak Louder than Its Actions. Available online: http://www.canada.com/story_print. html?id=83be7aa4-c0cb-4ee0-8a2f-9662d6b8e9bb (accessed on 4 December 2021).

170. Eric, S.; Gary, W.; Robert, C.B.; Ryan, P.; Desmond, R.; Warren, J. Integrated Pyrolysis Combined Cycle Biomass Power System Concept Definition; Alliant Energy: Madison, WI, USA, 2003.

171. Maniatis, K.; Baeyens, J.; Peeters, H.; Roggeman, G. The EGEMIN Flash Pyrolysis Process: Commissioning and Initial Results. In Advances in Thermochemical Biomass Conversion; Springer: Dordrecht, The Netherlands, 1993; pp. 1257-1264. 
172. Meier, D.; Eusterbrock, C.; Gannon, B. Ablative fast pyrolysis of biomass: A new demonstration project in California, USA. In ECI Symposium Series, Proceedings of the Pyroliq 2019: Pyrolysis and Liquefaction of Biomass and Wastes, Cork, Ireland, 16-20 June 2019; Berruti, F., Dufour, A., Prins, W., Garcia-Pérez, M., Eds.; ECI Digital Archives: New York, NY, USA, 2019. Available online: https:/ /dc.engconfintl.org/pyroliq_2019/32/ (accessed on 4 December 2021).

173. Honeywell UOP RTP Biomass Conversion-Renewable Fuels. Available online: https://uop.honeywell.com/en/industrysolutions/renewable-fuels/rtp-biomass-conversion (accessed on 19 May 2021).

174. Ensyn Corporation Ensyn, Arbec and Rémabec Begin Construction of the Cote Nord Biocrude Production Facility in Quebec; Ensyn News Release: Port-Cartier, QC, Canada, 2016. Available online: http://www.ensyn.com/uploads/6/9/7/8/69787119/cn_release_20 16.7.13_as_issued.pdf (accessed on 4 December 2021).

175. Ensyn Corporation Aracruz, Espirito Santo, Brazil-Initial Biocrude Production Facility under JV with Suzano. Available online: http:/ / www.ensyn.com/brazil.html (accessed on 4 December 2019).

176. Autio, J.; Lehto, J.; Oasmaa, A.; Solantausta, Y.; Jokela, P.; Alin, J.; Power, M. A Pyrolysis Pilot Unit Integrated to a Circulating Fluidized Bed Boiler-Experiences From a Pilot Project. In ECI Symposium Series, Proceedings of the 10th International Conference on Circulating Fluidized Beds and Fluidization Technology-CFB-10, Sun River, OR, USA, 1-5 May 2011; Knowlton, T., Ed.; ECI Digital Archives: New York, NY, USA, 2013. Available online: https:/ / dc.engconfintl.org/cfb10/19/ (accessed on 4 December 2021).

177. Independent Commodity Intelligence Services Lurgi to Start up Pyrolysis Plant. Available online: https://www.icis.com/ explore/resources/news/1999/05/17/80767/lurgi-to-start-up-pyrolysis-plant/ (accessed on 4 December 2021).

178. Diebold, J.P.; Scahill, J.W. Improved Vortex Reactor System 1995. Available online: https:/ / www.osti.gov/biblio/46290-improvedvortex-reactor-system (accessed on 4 December 2021).

179. Diebold, J.; Power, A. Engineering Aspects of the Vortex Pyrolysis Reactor to Produce Primary Pyrolysis Oil Vapors for Use in Resins and Adhesives. In Research in Thermochemical Biomass Conversion; Springer: Dordrecht, The Netherlands, 1988; pp. 609-628.

180. Yang, J.; Blanchette, D.; de Caumia, B.; Roy, C. Modelling, Scale-Up and Demonstration of a Vacuum Pyrolysis Reactor. In Progress in Thermochemical Biomass Conversion; Blackwell Science Ltd.: Oxford, UK, 2007; pp. 1296-1311.

181. Strezov, V.; Evans, T.J. Biomass Processing Technologies; CRC Press: Boca Raton, FL, USA, 2014; ISBN 9781482282603.

182. Badger, P. Demonstrating Bio-Oil Technology for Poultry Litter Management; ROI Alabama Operations LLC: Florence, AL, USA, 2006. Available online: http:/ / fppcinc.org/Assets/FPPC/PDF/reports_renewableoilinternational.pdf (accessed on 4 December 2021).

183. Neumann, J.; Jäger, N.; Apfelbacher, A.; Daschner, R.; Binder, S.; Hornung, A. Upgraded biofuel from residue biomass by Thermo-Catalytic Reforming and hydrodeoxygenation. Biomass Bioenergy 2016, 89, 91-97. [CrossRef]

184. Williams, P.T. Fuels, Chemicals and Materials from Waste. In Energy, Waste \& Resources-Three Sides of the Same Coin; The Royal Society of Chemistry: Environmental Chemistry Group: London, UK, 2012.

185. BTG Bioliquids. BTG-BTL Empyro Project. Available online: https://www.btg-btl.com/en/company/projects/empyro (accessed on 4 December 2019).

186. BTG-BTL Malaysia Plant. Available online: https://www.btg-btl.com/en/company/projects/malaysia (accessed on 4 December 2019).

187. Greiner, L. Thermochemical Process Converts Poultry Litter into Bio-Oil to Provide Safer and More Environmental Solution to Waste Disposal. Available online: https:/ / www.eurekalert.org/pub_releases/2007-08/vt-tpc081307.php (accessed on 4 December 2021).

188. Elliott, D.C. Biofuel from fast pyrolysis and catalytic hydrodeoxygenation. Curr. Opin. Chem. Eng. 2015, 9, 59-65. [CrossRef]

189. Dabros, T.M.H.; Stummann, M.Z.; Høj, M.; Jensen, P.A.; Grunwaldt, J.-D.; Gabrielsen, J.; Mortensen, P.M.; Jensen, A.D. Transportation fuels from biomass fast pyrolysis, catalytic hydrodeoxygenation, and catalytic fast hydropyrolysis. Prog. Energy Combust. Sci. 2018, 68, 268-309. [CrossRef]

190. Albrecht, K.O.; Olarte, M.V.; Wang, H. Upgrading Fast Pyrolysis Liquids. In Thermochemical Processing of Biomass; Brown, R.C., Ed.; John Wiley \& Sons, Ltd.: Chichester, UK, 2019; pp. 207-255.

191. Si, Z.; Zhang, X.; Wang, C.; Ma, L.; Dong, R. An Overview on Catalytic Hydrodeoxygenation of Pyrolysis Oil and Its Model Compounds. Catalysts 2017, 7, 169. [CrossRef]

192. Venderbosch, R.H.; Ardiyanti, A.R.; Wildschut, J.; Oasmaa, A.; Heeres, H.J. Stabilization of biomass-derived pyrolysis oils. J. Chem. Technol. Biotechnol. 2010, 85, 674-686. [CrossRef]

193. Negahdar, L.; Gonzalez-Quiroga, A.; Otyuskaya, D.; Toraman, H.E.; Liu, L.; Jastrzebski, J.T.B.H.; Van Geem, K.M.; Marin, G.B.; Thybaut, J.W.; Weckhuysen, B.M. Characterization and Comparison of Fast Pyrolysis Bio-oils from Pinewood, Rapeseed Cake, and Wheat Straw Using 13C NMR and Comprehensive GC $\times$ GC. ACS Sustain. Chem. Eng. 2016, 4, 4974-4985. [CrossRef]

194. Wang, H.; Male, J.; Wang, Y. Recent advances in hydrotreating of pyrolysis bio-oil and its oxygen-containing model compounds. ACS Catal. 2013, 3, 1047-1070. [CrossRef]

195. Saidi, M.; Samimi, F.; Karimipourfard, D.; Nimmanwudipong, T.; Gates, B.C.; Rahimpour, M.R. Upgrading of lignin-derived bio-oils by catalytic hydrodeoxygenation. Energy Environ. Sci. 2014, 7, 103-129. [CrossRef]

196. Elliott, D.C.; Wang, H.; French, R.; Deutch, S.; Iisa, K. Hydrocarbon liquid production from biomass via hot-vapor-filtered fast pyrolysis and catalytic hydroprocessing of the bio-oil. Energy Fuels 2014, 28, 5909-5917. [CrossRef]

197. Baldwin, R.M.; Feik, C.J. Bio-oil stabilization and upgrading by hot gas filtration. Energy Fuels 2013, 27, 3224-3238. [CrossRef]

198. Zhang, Q.; Xu, Y.; Li, Y.; Wang, T.; Zhang, Q.; Ma, L.; He, M.; Li, K. Investigation on the esterification by using supercritical ethanol for bio-oil upgrading. Appl. Energy 2015, 160, 633-640. [CrossRef] 
199. Xu, X.; Zhang, C.; Zhai, Y.; Liu, Y.; Zhang, R.; Tang, X. Upgrading of bio-oil using supercritical 1-butanol over a ru/c heterogeneous catalyst: Role of the solvent. Energy Fuels 2014, 28, 4611-4621. [CrossRef]

200. Tang, Z.; Lu, Q.; Zhang, Y.; Zhu, X.; Guo, Q. One step bio-oil upgrading through hydrotreatment, esterification, and cracking. Ind. Eng. Chem. Res. 2009, 48, 6923-6929. [CrossRef]

201. Oasmaa, A.; Czernik, S. Fuel oil quality of biomass pyrolysis oils—State of the art for the end users. Energy Fuels 1999, 13, 914-921. [CrossRef]

202. Diebold, J.P.P. A Review of the Chemical and Physical Mechanisms of the Storage Stability of Fast Pyrolysis Bio-Oils; National Renewable Energy Laboratory, Lakewood, CO, USA. 2000. Available online: https://www.nrel.gov/docs/fy00osti/27613.pdf (accessed on 4 December 2021).

203. Oasmaa, A.; Kuoppala, E.; Selin, J.F.; Gust, S.; Solantausta, Y. Fast pyrolysis of forestry residue and pine. 4. Improvement of the product quality by solvent addition. Energy Fuels 2004, 18, 1578-1583. [CrossRef]

204. Mercader, F.D.M.; Koehorst, P.J.J.; Heeres, H.J.; Kersten, S.R.A.; Hogendoorn, J.A. Competition Between Hydrotreating and Polymerization Reactions During Pyrolysis Oil Hydrodeoxygenation. AIChE J. 2011, 55, 3160-3170. [CrossRef]

205. Mercader, F.D.M. Pyrolysis Oil Upgrading for Co-Processing in Standard Refinery Units; University of Twente: Enschede, The Netherlands, 2010; ISBN 9789036530859.

206. Yin, W.; Venderbosch, R.H.; Heeres, H.J. Recent Developments in the Catalytic Hydrotreatment of Pyrolysis Liquids; Elsevier Ltd.: Amsterdam, The Netherlands, 2018; ISBN 9780081010259.

207. Zacher, A.H.; Olarte, M.V.; Santosa, D.M.; Elliott, D.C.; Jones, S.B. A review and perspective of recent bio-oil hydrotreating research. Green Chem. 2014, 16, 491-515. [CrossRef]

208. Mortensen, P.M.; Grunwaldt, J.D.; Jensen, P.A.; Knudsen, K.G.; Jensen, A.D. A review of catalytic upgrading of bio-oil to engine fuels. Appl. Catal. A Gen. 2011, 407,1-19. [CrossRef]

209. Boscagli, C.; Yang, C.; Welle, A.; Wang, W.; Behrens, S.; Raffelt, K.; Grunwaldt, J.D. Effect of pyrolysis oil components on the activity and selectivity of nickel-based catalysts during hydrotreatment. Appl. Catal. A Gen. 2017, 544, 161-172. [CrossRef]

210. Elliott, D.C.; Hart, T.R.; Neuenschwander, G.G.; Rotness, L.J.; Olarte, M.V.; Zacher, A.H.; Solantausta, Y. Catalytic hydroprocessing of fast pyrolysis bio-oil from pine sawdust. Energy Fuels 2012, 26, 3891-3896. [CrossRef]

211. Wildschut, J.; Iqbal, M.; Mahfud, F.H.; Cabrera, I.M.; Venderbosch, R.H.; Heeres, H.J. Insights in the hydrotreatment of fast pyrolysis oil using a ruthenium on carbon catalyst. Energy Environ. Sci. 2010, 3, 962. [CrossRef]

212. Talmadge, M.S.; Baldwin, R.M.; Biddy, M.J.; McCormick, R.L.; Beckham, G.T.; Ferguson, G.A.; Czernik, S.; Magrini-Bair, K.A.; Foust, T.D.; Metelski, P.D.; et al. A perspective on oxygenated species in the refinery integration of pyrolysis oil. Green Chem. 2014, 16, 407-453. [CrossRef]

213. Oasmaa, A.; Kuoppala, E.; Ardiyanti, A.; Venderbosch, R.H.; Heeres, H.J. Characterization of hydrotreated fast pyrolysis liquids. Energy Fuels 2010, 24, 5264-5272. [CrossRef]

214. Elliott, D.C.; Neuenschwander, G.G. Liquid fuels by low-severity hydrotreating of biocrude. Dev. Thermochem. Biomass Convers. 1996, 1, 611-621.

215. French, R.J.; Stunkel, J.; Black, S.; Myers, M.; Yung, M.M.; Iisa, K. Evaluate impact of catalyst type on oil yield and hydrogen consumption from mild hydrotreating. Energy Fuels 2014, 28, 3086-3095. [CrossRef]

216. Joshi, N.; Lawal, A. Hydrodeoxygenation of pyrolysis oil in a microreactor. Chem. Eng. Sci. 2012, 74, 1-8. [CrossRef]

217. Schmitt, C.C.; Zimina, A.; Fam, Y.; Raffelt, K.; Grunwaldt, J.-D.; Dahmen, N. Evaluation of High-Loaded Ni-Based Catalysts for Upgrading Fast Pyrolysis Bio-Oil. Catalysts 2019, 9, 784. [CrossRef]

218. Bozell, J.J.; Holladay, J.E.; Johnson, D.; White, J.F. Top Value-Added Chemicals from Biomass Volume II-Results of Screening for Potential Candidates from Biorefinery Lignin PNNL-16983; Pacific Northwest National Laboratory: Richland, WA, USA, 2007; Volume II. Available online: https:/ / www.pnnl.gov/main/publications/external/technical_reports/PNNL-16983.pdf (accessed on 4 December 2021).

219. Pires, A.P.P.; Arauzo, J.; Fonts, I.; Domine, M.E.; Arroyo, A.F.; Garcia-Perez, M.E.M.M.E.; Montoya, J.; Chejne, F.; Pfromm, P.; Garcia-Perez, M.E.M.M.E. Challenges and opportunities for bio-oil refining: A review. Energy Fuels 2019, 33, 4683-4720. [CrossRef]

220. Elliott, D.C. Historical Developments in Hydroprocessing Bio-oils. Energy Fuels 2007, 21, 1792-1815. [CrossRef]

221. Shafaghat, H.; Rezaei, P.S.; Ashri Wan Daud, W.M. Effective parameters on selective catalytic hydrodeoxygenation of phenolic compounds of pyrolysis bio-oil to high-value hydrocarbons. RSC Adv. 2015, 5, 103999-104042. [CrossRef]

222. Şenol, O.I.; Viljava, T.R.; Krause, A.O.I. Hydrodeoxygenation of methyl esters on sulphided $\mathrm{NiMo} / \gamma-\mathrm{Al}_{2} \mathrm{O}_{3}$ and $\mathrm{CoMo} / \gamma-\mathrm{Al}_{2} \mathrm{O}_{3}$ catalysts. Catal. Today 2005, 100, 331-335. [CrossRef]

223. Auersvald, M.; Shumeiko, B.; Vrtiška, D.; Straka, P.; Staš, M.; Šimáček, P.; Blažek, J.; Kubička, D. Hydrotreatment of straw bio-oil from ablative fast pyrolysis to produce suitable refinery intermediates. Fuel 2019, 238, 98-110. [CrossRef]

224. Gholizadeh, M.; Gunawan, R.; Hu, X.; Hasan, M.M.; Kersten, S.; Westerhof, R.; Chaitwat, W.; Li, C.Z. Different reaction behaviours of the light and heavy components of bio-oil during the hydrotreatment in a continuous pack-bed reactor. Fuel Process. Technol. 2016, 146, 76-84. [CrossRef]

225. He, Z.; Wang, X. Hydrodeoxygenation of model compounds and catalytic systems for pyrolysis bio-oils upgrading. Catal. Sustain. Energy 2012, 1, 28-52. [CrossRef] 
226. Romero, Y.; Richard, F.; Brunet, S. Hydrodeoxygenation of 2-ethylphenol as a model compound of bio-crude over sulfided Mo-based catalysts: Promoting effect and reaction mechanism. Appl. Catal. B Environ. 2010, 98, 213-223. [CrossRef]

227. Wan, H.; Chaudhari, R.V.; Subramaniam, B. Aqueous phase hydrogenation of acetic acid and its promotional effect on p-cresol hydrodeoxygenation. Energy Fuels 2013, 27, 487-493. [CrossRef]

228. Gholizadeh, M.; Gunawan, R.; Hu, X.; De Miguel Mercader, F.; Westerhof, R.; Chaitwat, W.; Hasan, M.M.; Mourant, D.; Li, C.Z Effects of temperature on the hydrotreatment behaviour of pyrolysis bio-oil and coke formation in a continuous hydrotreatment reactor. Fuel Process. Technol. 2016, 148, 175-183. [CrossRef]

229. Silva, A.C.; de Barros, M.R.; Macedo, K.S.; Silva, E.M.S. Ferroniobium Alloy Fines Agglomeration through Briquetting. Tecnol. Metal. Mater. Mineração 2019, 16, 414-420. [CrossRef]

230. Nowak, I.; Ziolek, M. Niobium Compounds: Preparation, Characterization, and Application in Heterogeneous Catalysis. Chem. Rev. 1999, 99, 3603-3624. [CrossRef] [PubMed]

231. Nico, C.; Monteiro, T.; Graça, M.P.F. Niobium oxides and niobates physical properties: Review and prospects. Prog. Mater. Sci. 2016, 80, 1-37. [CrossRef]

232. Schäfer, H.; Gruehn, T.; Schulte, F. The Modifications of Niobium Pentoxide. Angew. Chemie-Int. Ed. 1966, 5, 40-52. [CrossRef]

233. Ko, E.I.; Weissman, J.G. Structures of Niobium Pentoxide and their Implications on Chemical Behavior. Catal. Today 1990, 8, 27-36. [CrossRef]

234. Rani, R.A.; Zoolfakar, A.S.; O'Mullane, A.P.; Austin, M.W.; Kalantar-Zadeh, K. Thin films and nanostructures of niobium pentoxide: Fundamental properties, synthesis methods and applications. J. Mater. Chem. A 2014, 2, 15683-15703. [CrossRef]

235. Meng, J.; He, Q.; Xu, L.; Zhang, X.; Liu, F.; Wang, X.; Li, Q.; Xu, X.; Zhang, G.; Niu, C.; et al. Identification of Phase Control of Carbon-Confined Nb $2 \mathrm{O} 5$ Nanoparticles toward High-Performance Lithium Storage. Adv. Energy Mater. 2019, 9, 18. [CrossRef]

236. Chan, X.; Pu, T.; Chen, X.; James, A.; Lee, J.; Parise, J.B.; Kim, D.H.; Kim, T. Effect of niobium oxide phase on the furfuryl alcohol dehydration. Catal. Commun. 2017, 97, 65-69. [CrossRef]

237. Tanabe, K. Catalytic applications of niobium compounds. Niobium. Sci. Technol. 2001, 78, 269-290.

238. Noronha, F.B.; Frydman, A.; Aranda, D.A.G.; Perez, C.; Soares, R.R.; Morawek, B.; Castner, D.; Campbell, C.T.; Frety, R.; Schmal, M. The promoting effect of noble metal addition on niobia-supported cobalt catalysts. Catal. Today 1996, 28, 147-157. [CrossRef]

239. Passos, F.B.; Aranda, D.A.G.; Soares, R.R.; Schmal, M. Effect of preparation method on the properties of $\mathrm{Nb}_{2} \mathrm{O}_{5}$ promoted platinum catalysts. Catal. Today 1998, 43, 3-9. [CrossRef]

240. Barrios, A.M.; Teles, C.A.; de Souza, P.M.; Rabelo-Neto, R.C.; Jacobs, G.; Davis, B.H.; Borges, L.E.P.; Noronha, F.B. Hydrodeoxygenation of phenol over niobia supported Pd catalyst. Catal. Today 2018, 302, 115-124. [CrossRef]

241. Shao, Y.; Xia, Q.; Dong, L.; Liu, X.; Han, X.; Parker, S.F.; Cheng, Y.; Daemen, L.L.; Ramirez-Cuesta, A.J.; Yang, S.; et al. Selective production of arenes via direct lignin upgrading over a niobium-based catalyst. Nat. Commun. 2017, 8, 1-9. [CrossRef]

242. Dong, L.; Shao, Y.; Han, X.; Liu, X.; Xia, Q.; Parker, S.F.; Cheng, Y.; Daemen, L.L.; Ramirez-Cuesta, A.J.; Wang, Y.; et al. Comparison of two multifunctional catalysts $\left[\mathrm{M} / \mathrm{Nb}_{2} \mathrm{O}_{5}(\mathrm{M}=\mathrm{Pd}, \mathrm{Pt})\right]$ for one-pot hydrodeoxygenation of lignin. Catal. Sci. Technol. 2018, 8, 6129-6136. [CrossRef]

243. Li, L.; Dong, L.; Liu, X.; Guo, Y.; Wang, Y. Selective production of ethylbenzene from lignin oil over FeOx modified $\mathrm{Ru} / \mathrm{Nb}_{2} \mathrm{O}_{5}$ catalyst. Appl. Catal. B Environ. 2020, 260, 118143. [CrossRef]

244. Xin, Y.; Dong, L.; Guo, Y.; Liu, X.; Hu, Y.; Wang, Y. Correlation of the catalytic performance with $\mathrm{Nb}_{2} \mathrm{O}_{5}$ surface properties in the hydrodeoxygenation of lignin model compound. J. Catal. 2019, 375, 202-212. [CrossRef]

245. Jing, Y.; Xin, Y.; Guo, Y.; Liu, X.; Wang, Y. Highly efficient $\mathrm{Nb}_{2} \mathrm{O}_{5}$ catalyst for aldol condensation of biomass-derived carbonyl molecules to fuel precursors. Chin. J. Catal. 2019, 40, 1168-1177. [CrossRef]

246. Resende, K.A.; Braga, A.H.; Noronha, F.B.; Hori, C.E. Hydrodeoxygenation of phenol over Ni/Ce1-xNbxO2 catalysts. Appl. Catal. B Environ. 2019, 245, 100-113. [CrossRef]

247. Jin, S.; Guan, W.; Tsang, C.W.; Yan, D.Y.S.; Chan, C.Y.; Liang, C. Enhanced Hydroconversion of Lignin-Derived Oxygen-Containing Compounds Over Bulk Nickel Catalysts Though $\mathrm{Nb}_{2} \mathrm{O}_{5}$ Modification. Catal. Lett. 2017, 147, 2215-2224. [CrossRef]

248. Xue, F.; Ma, D.; Tong, T.; Liu, X.; Hu, Y.; Guo, Y.; Wang, Y. Contribution of Different NbOx Species in the Hydrodeoxygenation of 2,5-Dimethyltetrahydrofuran to Hexane. ACS Sustain. Chem. Eng. 2018, 6, 13107-13113. [CrossRef]

249. Shao, Y.; Xia, Q.; Liu, X.; Lu, G.; Wang, Y. Pd/ $\mathrm{Nb}_{2} \mathrm{O}_{5} / \mathrm{SiO}_{2}$ Catalyst for the Direct Hydrodeoxygenation of Biomass-Related Compounds to Liquid Alkanes under Mild Conditions. ChemSusChem 2015, 8, 1761-1767. [CrossRef] [PubMed]

250. Infantes-Molina, A.; Moretti, E.; Segovia, E.; Lenarda, A.; Rodríguez-Castellón, E. Pd-Nb binfunctional catalysts supported on silica and zirconium phosphate heterostructures for O-removal of dibenzofurane. Catal. Today 2016, 277, 143-151. [CrossRef]

251. Guan, W.; Chen, X.; Li, C.; Zhang, J.; Tsang, C.W.; Hu, H.; Li, S.; Liang, C. Nb(Ta)-based solid acid modified Pt/CNTs catalysts for hydrodeoxygenation of lignin-derived compounds. Mol. Catal. 2019, 467, 61-69. [CrossRef]

252. Zhang, C.; Jia, C.; Cao, Y.; Yao, Y.; Xie, S.; Zhang, S.; Lin, H. Water-assisted selective hydrodeoxygenation of phenol to benzene over the Ru composite catalyst in the biphasic process. Green Chem. 2019, 21, 1668-1679. [CrossRef]

253. Jeon, S.; Park, Y.M.; Park, J.; Saravanan, K.; Jeong, H.K.; Bae, J.W. Synergistic effects of $\mathrm{Nb}_{2} \mathrm{O}_{5}$ promoter on $\mathrm{Ru} / \mathrm{Al}_{2} \mathrm{O}_{3}$ for an aqueous-phase hydrodeoxygenation of glycerol to hydrocarbons. Appl. Catal. A Gen. 2018, 551, 49-62. [CrossRef] 
254. Leal, G.F.; Lima, S.; Graça, I.; Carrer, H.; Barrett, D.H.; Teixeira-Neto, E.; Curvelo, A.A.S.; Rodella, C.B.; Rinaldi, R. Design of Nickel Supported on Water-Tolerant $\mathrm{Nb}_{2} \mathrm{O}_{5}$ Catalysts for the Hydrotreating of Lignin Streams Obtained from Lignin-First Biorefining. iScience 2019, 15, 467-488. [CrossRef] [PubMed]

255. Ma, D.; Lu, S.; Liu, X.; Guo, Y.; Wang, Y. Depolymerization and hydrodeoxygenation of lignin to aromatic hydrocarbons with a $\mathrm{Ru}$ catalyst on a variety of Nb-based supports. Chin. J. Catal. 2019, 40, 609-617. [CrossRef]

256. Teles, C.A.; de Souza, P.M.; Rabelo-Neto, R.C.; Griffin, M.B.; Mukarakate, C.; Orton, K.A.; Resasco, D.E.; Noronha, F.B. Catalytic upgrading of biomass pyrolysis vapors and model compounds using niobia supported Pd catalyst. Appl. Catal. B Environ. 2018, 238, 38-50. [CrossRef]

257. Mortensen, P.M.; Grunwaldt, J.D.; Jensen, P.A.; Jensen, A.D. Screening of catalysts for hydrodeoxygenation of phenol as a model compound for bio-oil. ACS Catal. 2013, 3, 1774-1785. [CrossRef]

258. Ardiyanti, A.R.; Bykova, M.V.; Khromova, S.A.; Yin, W.; Venderbosch, R.H.; Yakovlev, V.A.; Heeres, H.J. Ni-Based Catalysts for the Hydrotreatment of Fast Pyrolysis Oil. Energy Fuels 2016, 30, 1544-1554. [CrossRef]

259. Ardiyanti, A.R.; Khromova, S.A.; Venderbosch, R.H.; Yakovlev, V.A.; Melián-Cabrera, I.V.; Heeres, H.J. Catalytic hydrotreatment of fast pyrolysis oil using bimetallic Ni-Cu catalysts on various supports. Appl. Catal. A Gen. 2012, 449, 121-130. [CrossRef]

260. Ardiyani, A.R.; Khromova, S.A.; Venderbosch, R.H.; Yakovlev, V.A.; Heeres, H.J. Catalytic hydrotreatment of fast-pyrolysis oil using non-sulfided bimetallic Ni-Cu catalysts on a $\delta$-Al2O3 support. Appl. Catal. B Environ. 2012, 117-118, 105-117. [CrossRef]

261. Mortensen, P.M.; Gardini, D.; de Carvalho, H.W.P.; Damsgaard, C.D.; Grunwaldt, J.; Jensen, P.A.; Wagner, J.B.; Jensen, A.D Stability and resistance of nickel catalysts for hydrodeoxygenation: Carbon deposition and effects of sulfur, potassium, and chlorine in the feed. Catal. Sci. Technol. 2014, 4, 3672-3686. [CrossRef]

262. Mortensen, P.M.; Grunwaldt, J.D.; Jensen, P.A.; Jensen, A.D. Influence on nickel particle size on the hydrodeoxygenation of phenol over $\mathrm{Ni} / \mathrm{SiO}_{2}$. Catal. Today 2016, 259, 277-284. [CrossRef]

263. Boscagli, C.; Raffelt, K.; Zevaco, T.A.; Olbrich, W.; Otto, T.N.; Sauer, J.; Grunwaldt, J.D. Mild hydrotreatment of the light fraction of fast-pyrolysis oil produced from straw over nickel-based catalysts. Biomass Bioenergy 2015, 83, 525-538. [CrossRef]

264. Argyle, M.D.; Bartholomew, C.H. Heterogeneous Catalyst Deactivation and Regeneration: A Review. Catalysts 2015, 5, 145-269. [CrossRef]

265. Sultana, A.; Kumar, A. Optimal configuration and combination of multiple lignocellulosic biomass feedstocks delivery to a biorefinery. Bioresour. Technol. 2011, 102, 9947-9956. [CrossRef] [PubMed]

266. Demirbaş, A. Biomass resource facilities and biomass conversion processing for fuels and chemicals. Energy Convers. Manag. 2001, 42, 1357-1378. [CrossRef]

267. Jonutis, V. The Biomass Exchange-virtual transmission gird in biomass markets. In Proceedings of the IEA Bioenergy workshop: Developing business models for efficient use of biomass, Tallinn, Estonia, 22 October 2019.

268. Dimitriou, I. SWOT of bio-hubs in deploying biobased supply chains. In Proceedings of the IEA Bioenergy workshop: Developing business models for efficient use of biomass, Tallinn, Estonia, 22 October 2019.

269. Annevelink, B. Examples of developing biobased business models: Session conclusions. In Proceedings of the IEA Bioenergy workshop: Developing business models for efficient use of biomass, Tallinn, Estonia, 22 October 2019.

270. Maung, T.A.; Gustafson, C.R.; Saxowsky, D.M.; Nowatzki, J.; Miljkovic, T.; Ripplinger, D. The logistics of supplying single vs. multi-crop cellulosic feedstocks to a biorefinery in southeast North Dakota. Appl. Energy 2013, 109, 229-238. [CrossRef]

271. Brown, D.; Rowe, A.; Wild, P. A techno-economic analysis of using mobile distributed pyrolysis facilities to deliver a forest residue resource. Bioresour. Technol. 2013, 150, 367-376. [CrossRef]

272. Brown, M. Enabling a Regional Bioeconomy: Australian case study for developing biomass supply chains. In Proceedings of the IEA Bioenergy Workshop: Developing Business Models for Efficient Use of Biomass, Tallinn, Estonia, 22 October 2019.

273. Kärki, J. Outlook on bioenergy combined with carbon capture, utilization and storage (BECCUS). In Proceedings of the IEA Bioenergy Workshop: Developing Business Models for Efficient Use of Biomass, Tallinn, Estonia, 22 October 2019.

274. Consoli, C. Bioenergy and Carbon Capture and Storage; Global CCS Institute: Melbourne, Australia, 2019.

275. Lindroos, T.J.; Rydén, M.; Langørgen, Ø.; Pursiheimo, E.; Pikkarainen, T. Robust decision making analysis of BECCS (bio-CLC) in a district heating and cooling grid. Sustain. Energy Technol. Assess. 2019, 34, 157-172. [CrossRef]

276. van Dyk, S.; Su, J.; Mcmillan, J.D.; Saddler, J. Potential synergies of drop-in biofuel production with further co-processing at oil refineries. Biofuels Bioprod. Biorefining 2019, 13, 760-775. [CrossRef]

277. Brown, R.C. PY Refinery: Thermal fractionation of lignocellulosic biomass into diverse biobased products. In Proceedings of the Frontiers in Biorefining, St. Simons Island, GA, USA, 21-24 October 2014.

278. Ceccarelli, C. Bioliq-Startseite. Available online: https://www.bioliq.de/ (accessed on 19 May 2021).

279. Venderbosch, R.; Heeres, H. Stabilisation of Biomass derived Pyrolysis Oils by Catalytic Hydrotreatment. InTech 2011. Available online: https: / / www.intechopen.com/chapters/17490 (accessed on 4 December 2021).

280. Valle, B.; Aramburu, B.; Santiviago, C.; Bilbao, J.; Gayubo, A.G. Upgrading of Bio-Oil in a Continuous Process with Dolomite Catalyst. Energy Fuels 2014, 28, 6419-6428. [CrossRef]

281. Graglia, M.; Kanna, N.; Esposito, D. Lignin Refinery: Towards the Preparation of Renewable Aromatic Building Blocks. ChemBioEng. Rev. 2015, 2, 377-392. [CrossRef]

282. Zakzeski, J.; Bruijnincx, P.C.A.; Jongerius, A.L.; Weckhuysen, B.M. The Catalytic Valorization of Ligning for the Production of Renewable Chemicals. Chem. Rev. 2010, 110, 3552-3599. [CrossRef] 
283. Sun, Z.; Fridrich, B.; De Santi, A.; Elangovan, S.; Barta, K. Bright Side of Lignin Depolymerization: Toward New Platform Chemicals. Chem. Rev. 2018, 118, 614-678. [CrossRef] [PubMed]

284. Jin, S.; Xiao, Z.; Li, C.; Chen, X.; Wang, L.; Xing, J.; Li, W.; Liang, C. Catalytic hydrodeoxygenation of anisole as lignin model compound over supported nickel catalysts. Catal. Today 2014, 234, 125-132. [CrossRef]

285. Izquierdo, U.; Barrio, V.L.; Cambra, J.F.; Requies, J.; Güemez, M.B.; Arias, P.L.; Kolb, G.; Zapf, R.; Gutiérrez, A.M.; Arraibi, J.R Hydrogen production from methane and natural gas steam reforming in conventional and microreactor reaction systems. Int. J. Hydrogen Energy 2012, 37, 7026-7033. [CrossRef]

286. Lap, T.; Benders, R.; Köberle, A.; van der Hilst, F.; Nogueira, L.; Szklo, A.; Schaeffer, R.; Faaij, A. Pathways for a Brazilian biobased economy: Towards optimal utilization of biomass. Biofuels Bioprod. Biorefining 2019, 13, 673-689. [CrossRef]

287. Lap, T.; Benders, R.; van der Hilst, F.; Faaij, A. How does the interplay between resource availability, intersectoral competition and reliability affect a low-carbon power generation mix in Brazil for 2050? Energy 2020, 195, 116948. [CrossRef] 